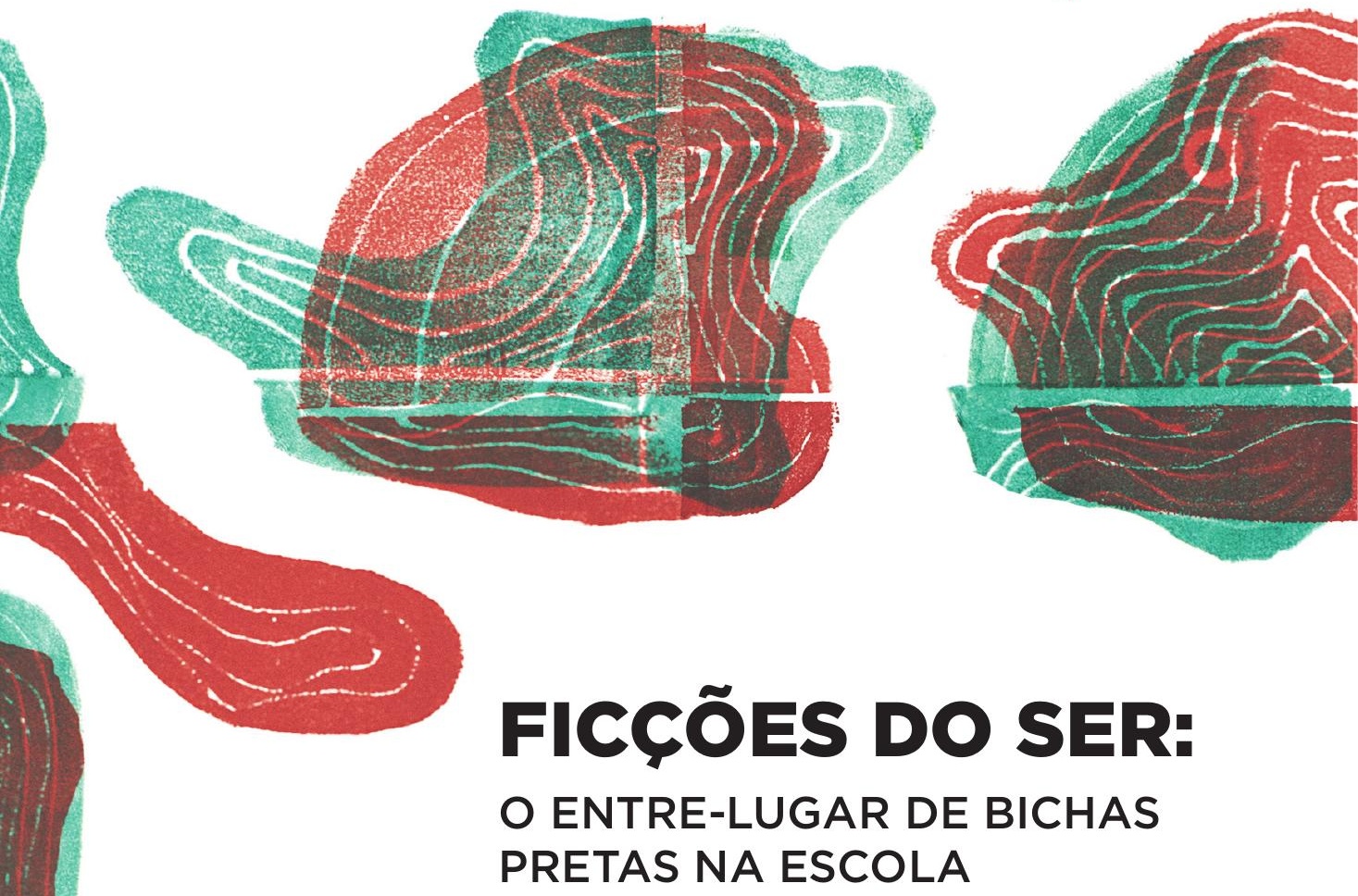

KAUAN ALMEIDA
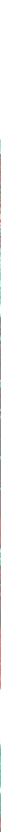

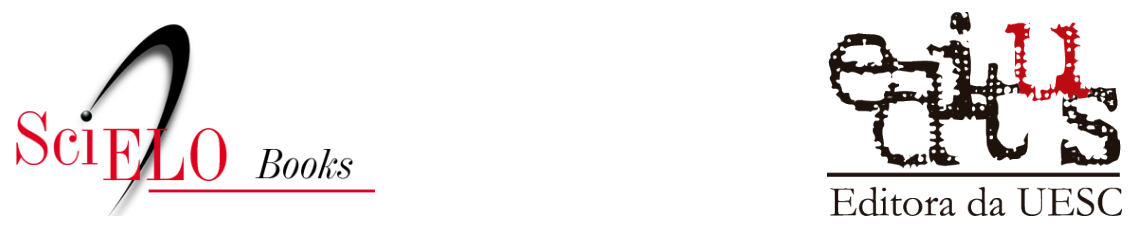

\title{
Ficções do ser \\ o entre-lugar de bichas pretas na escola
}

\author{
Kauan Almeida
}

\section{SciELO Books / SciELO Livros / SciELO Libros}

ALMEIDA, K. Ficções do ser: o entre-lugar de bichas pretas na escola [online]. Ilhéus, BA: Editus, 2020, 167 p. Transfluência series. ISBN: 978-65-86213-15-7. https://doi.org/10.7476/9786586213300.

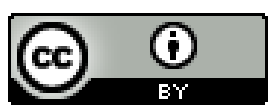

All the contents of this work, except where otherwise noted, is licensed under a Creative Commons Attribution 4.0 International license.

Todo o conteúdo deste trabalho, exceto quando houver ressalva, é publicado sob a licença Creative Commons Atribição 4.0.

Todo el contenido de esta obra, excepto donde se indique lo contrario, está bajo licencia de la licencia Creative Commons Reconocimento 4.0. 


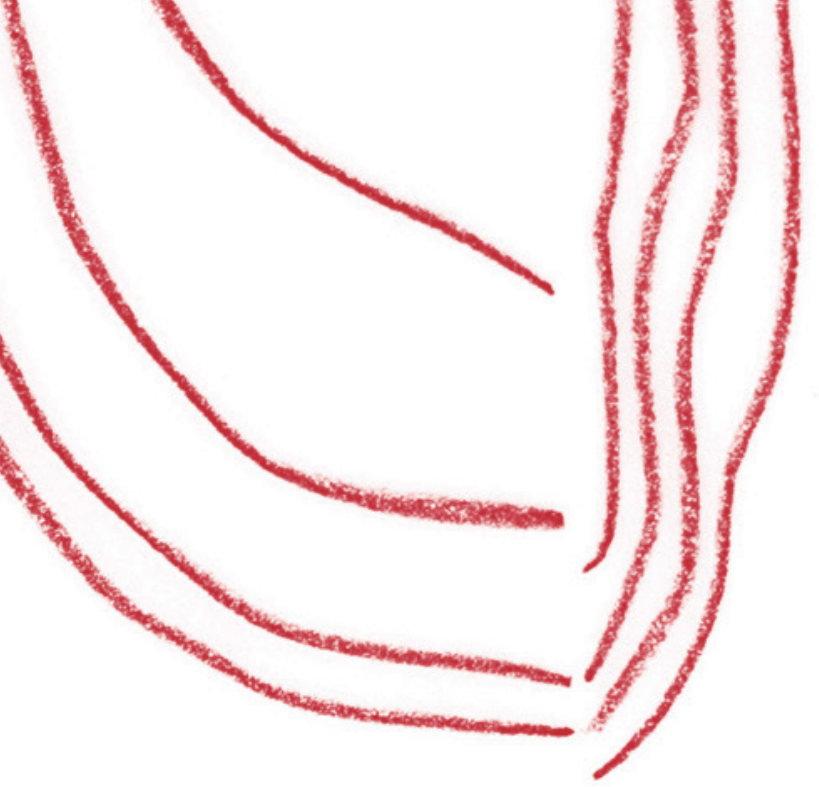

\section{FICÇÕES DO SER: O ENTRE-LUGAR DE BICHAS PRETAS NA ESCOLA}

KAUAN ALMEIDA
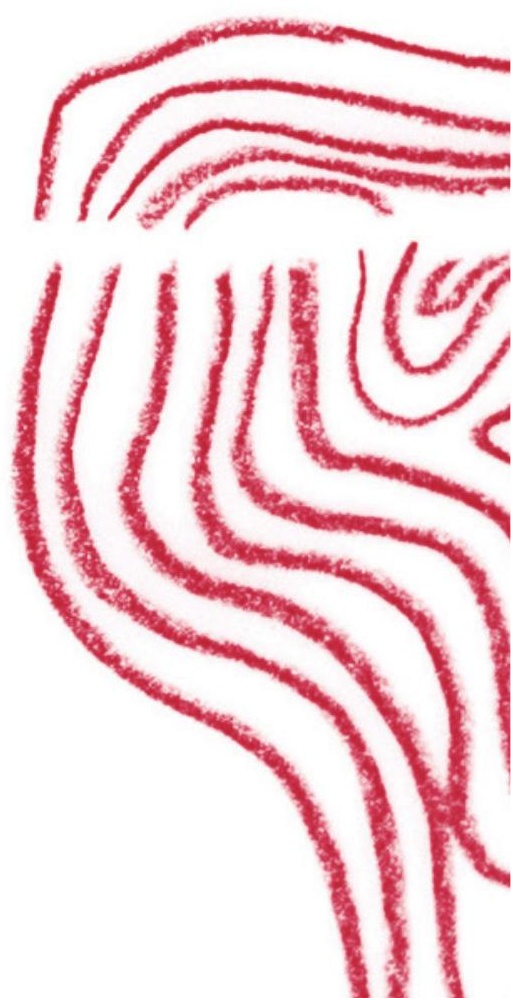


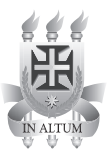

\section{Universidade Estadual de Santa Cruz}

DIRETORA DA EDITUS

Rita Virginia Alves Santos Argollo

\section{Conselho Editorial:}

Rita Virginia Alves Santos Argollo - Presidente Alexandra Marselha Siqueira Pitolli Andréa de Azevedo Morégula Carlos Pereira Neto

Dejeane de Oliveira Silva Iracildo Silva Santos

Helga Dulce Bispo Passos Luciana Sedano de Souza Lurdes Bertol Rocha Maria Cristina Rangel Maria Luiza Silva Santos Maurício Santana Moreau Raquel da Silva Ortega Sabrina Nascimento

GOVERNO DO ESTADO DA BAHIA

Rui Costa - Governador

\section{SECRETARIA DE EDUCAÇÃO}

Jerônimo Rodrigues - Secretário

UNIVERSIDADE ESTADUAL DE SANTA CRUZ Alessandro Fernandes de Santana - Reitor Maurício Santana Moreau - Vice-Reitor

\section{Universidade Federal do Sul da Bahia - UFSB}

Reitora Joana Angélica Guimarães da Luz Vice-Reitor Francisco José Gomes Mesquita Pró-Reitor de Pesquisa e Pós-Graduação Rogério Hermida Quintella Diretor de Pós-Graduação Nadson Ressye Simões da Silva

Programa de Pós-Graduação em Ensino e Relações Étnico-Raciais - PPGER

Coordenação Geral PPGER Cynthia de Cássia Santos Barra Coordenação PPGER, campus Sosígenes Costa Eliana Póvoas Pereira Estrela Brito Coordenação PPGER, campus Paulo Freire Gilson Brandão de Oliveira Júnior

Projeto Transfluência: Ensino, Gênero, Relações Étnico-Raciais

Coordenação Editorial

Cynthia de Cássia Santos Barra Laura Castro de Araújo

\section{Comissão de Seleção de Obras - PPGER/UFSB} Apoena Dandara Silva Santos Cynthia de Cássia Santos Barra Francisco A. Nascimento Junior Francisco Antônio Nunes Neto Hamilton Richard A. F. Santos Laura Castro de Araújo Paulo César Pereira de Jesus Rebeca Valadão Bussinger Yuri Miguel Macedo 


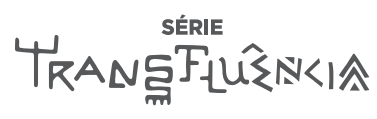

\section{FICÇÕES DO SER: O ENTRE-LUGAR DE BICHAS PRETAS NA ESCOLA}

KAUAN ALMEIDA

Ilhéus - Bahia 2020
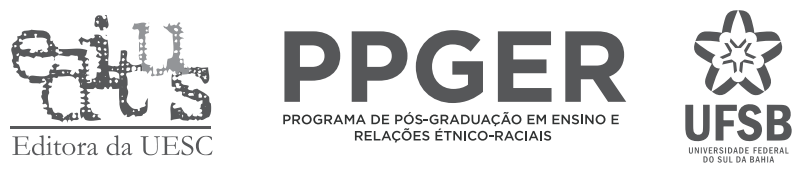
Copyright (C)2020 by KaUAN SANTOS ALMEIDA

Direitos desta edição reservados à

EDITUS - EDITORA DA UESC

PPGER/UFSB

A reprodução não autorizada desta publicação, por qualquer meio, seja total ou parcial, constitui violação da Lei n ${ }^{\circ}$ 9.610/98.

Depósito legal na Biblioteca Nacional,

conforme Lei ${ }^{\circ}{ }^{0} 10.994$, de 14 de dezembro de 2004.

\section{GERÊNCIA DE PRODUÇÃO}

Sabrina Nascimento

\section{PROJETO GRÁFICO}

Lia Cunha

Tiago Ribeiro

FINALIZAÇÃO

Deise Francis Krause

REVISÃO

Pedro de Carvalho Neto

Tess Chamusca Pirajá

Dados Internacionais de Catalogação na Publicação (CIP)

A447 Almeida, Kauan

Ficções do ser: o entre-lugar de bichas pretas na

escola / Kauan Almeida. - Ilhéus, BA: Editus, 2020.

167p. - (Transfluência)

Referências: p. 143-151.

ISBN: 978-65-86213-15-7

1. Currículos. 2. Educação - Aspectos

sociais. 3. Racismo. 4. Homofobia nas escolas. 5.

Multiculturalismo. I. Título.

CDD 373.19

Elaborado por Quele Pinheiro Valença CRB 5/1533

EDITUS - EDITORA DA UESC

Universidade Estadual de Santa Cruz

Rodovia Jorge Amado, km 16 - 45662-90o - Ilhéus, Bahia, Brasil

Tel.: (73) 3680-5028

www.uesc.br/editora

editus@uesc.br

EDITORA FILIADA À

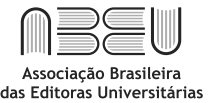




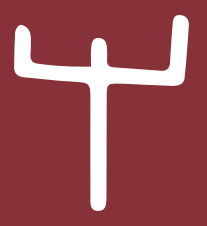



A coisa contra a coisa: a inútil crueldade da análise. O cruel saber que despedaça o ser sabido.

A vida contra a coisa:

a violentação da forma, recriando-a em sínteses humanas sábias e inúteis.

A vida contra a vida: a estéril crueldade da luz que se consome desintegrando a essência inutilmente.

Orides Fontela, Destruição 

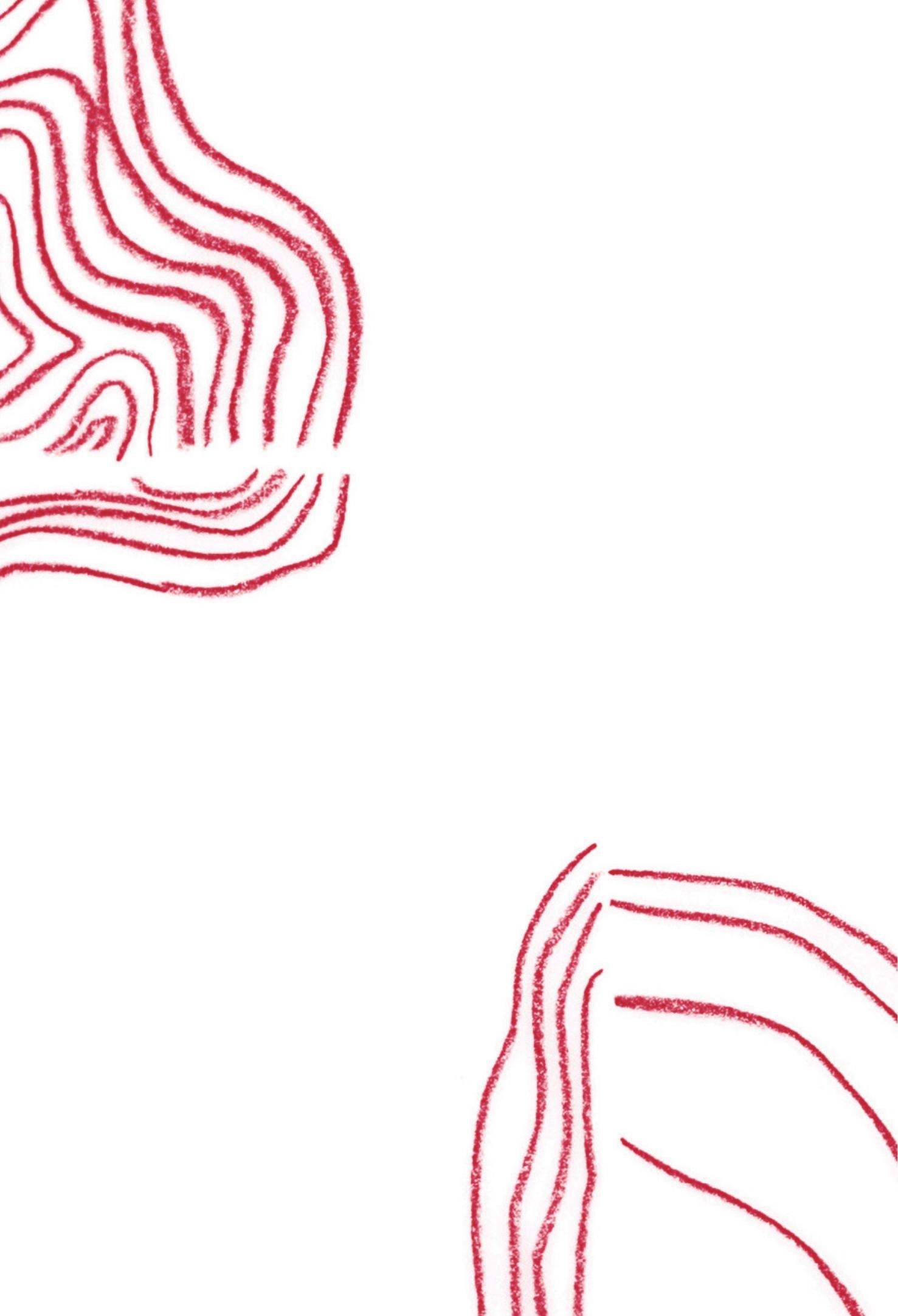


\section{sumário}

13

apresentação | Kabengele Munanga

21 A você, leitora!

39 Pela metade: notas de um quase início

54 Anti-princípios metodológicos: manual de anti-ajuda para pesquisadoras à deriva

63 Analítica do desejo em um currículo

69 "Todas nós nascemos nus e o resto é drag": devir-bicha em um currículo

79 Cena I - Pode um currículo festejar?

93 Cena II - Fazer a escola fugir

103 "Por que tu me chamas se não me conheces?": devir-negro em um currículo

111 Cena III - O que pode uma bicha preta no Novembro Negro? 


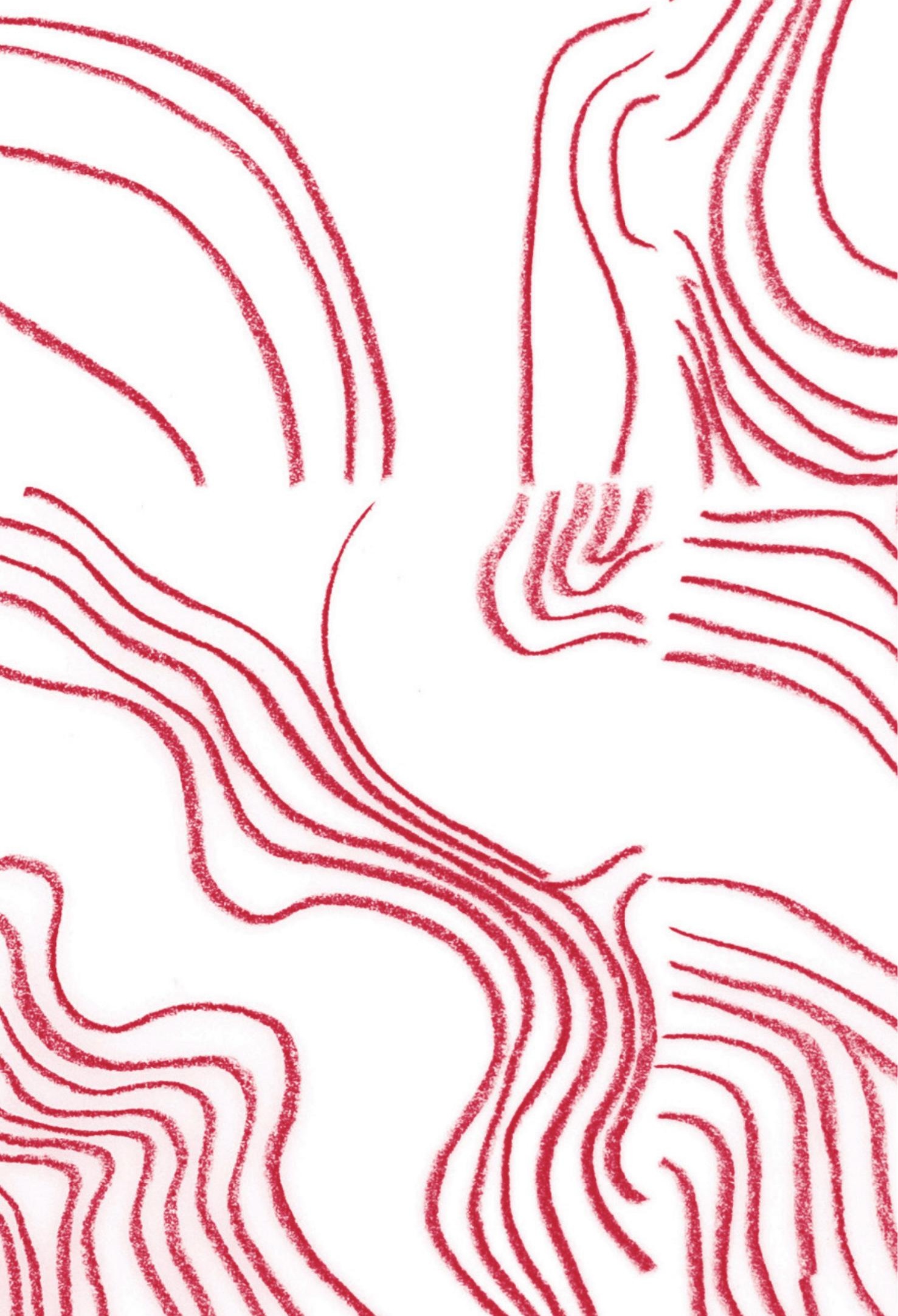


124 Cena IV - "O now-frágil" (ou a tarefa de um fugitivo)

135 Notas de um quase fim

143 referências

153 posfácio|Cynthia Cy Barra e Laura Castro

167 sobre o autor 


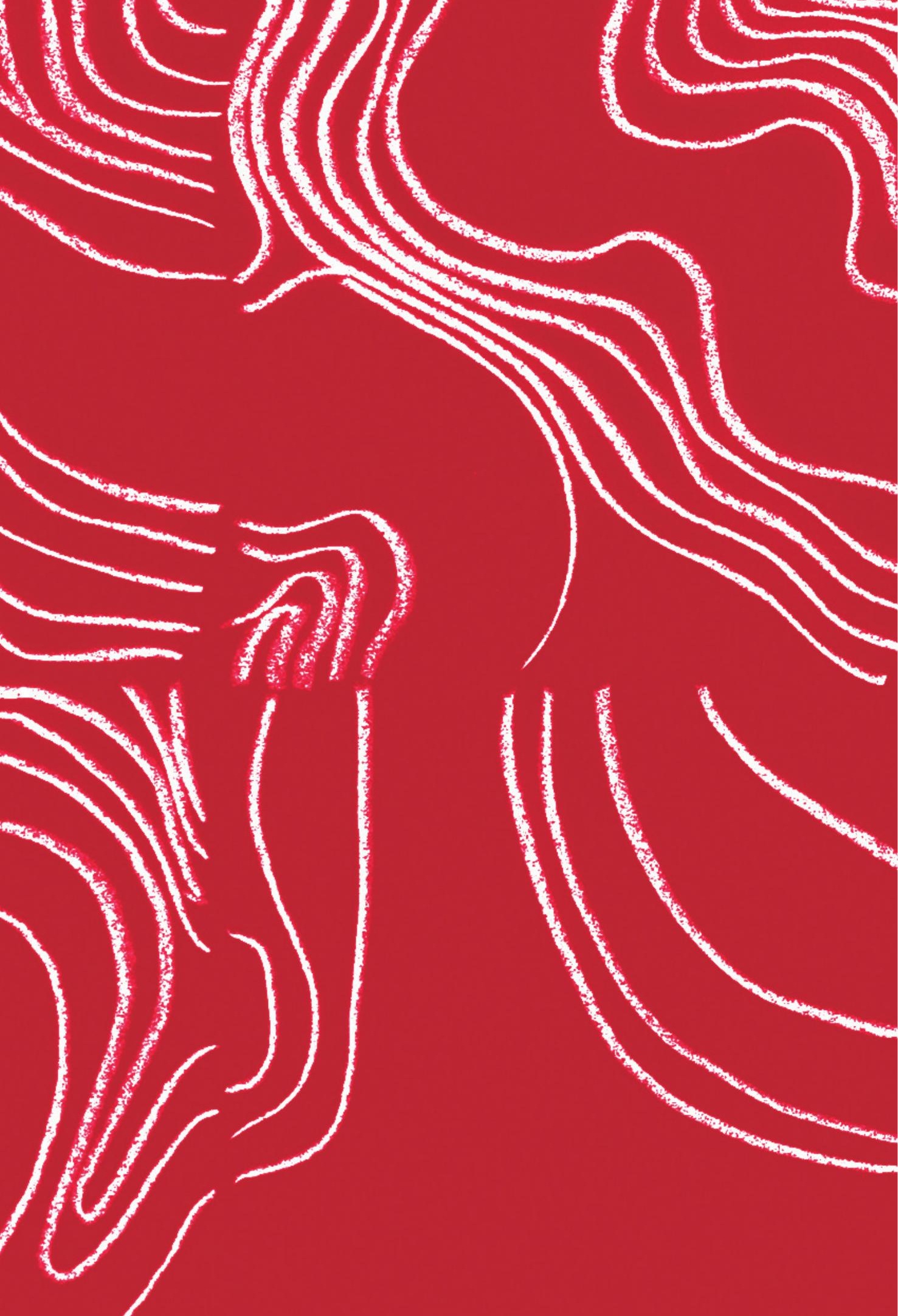




\section{apresentação}

A diversidade e suas diferenças fornecem a matéria prima utilizada nos processos de construção de todas as identidades individuais e coletivas. Essa matéria prima está na geografia dos corpos das pessoas e sociedades, em suas histórias, em suas culturas, em suas línguas e comportamentos individuais e coletivos. A diversidade e as diferenças estão presentes na natureza, entre plantas e animais, entre minerais, mas nunca foram classificadas hierarquicamente em superiores e inferiores como se fez com os seres e sociedades humanos. Apesar do estranhamento da diferença na percepção do outro, este deveria ser considerado como contemporâneo e igual sem degradação da diferença em desigualdade.

As diferenças biológicas - que fazem com que sejamos homens e mulheres; brancos, negros e amarelos; jovens e veIhos, etc. - são inatas. Ninguém escolheu pais brancos, negros ou amarelos, antes de nascer; ninguém escolheu para ser homem ou mulher; ninguém pode escolher para permanecer eternamente jovens ou para não envelhecer, ninguém escolheu para ser heterossexual ou homossexual.

A essas diferenças naturais inatas - que fazem de nós brancos, negros, amarelos; homens, mulheres, jovens, velhos 
- se acrescentam outras diferenças de ordem cultural e socioeconômica que são adquiridas. Pois pertencemos todos às sociedades humanas que criaram e desenvolveram culturas. Isto é, a totalidade de maneiras de viver, de trabalhar, de pensar e a totalidade daquilo que resulta dessas atividades (instituições, educação, filosofia, organização social, religião, etc.). Pertencemos também às sociedades que política e economicamente criaram classes sociais: ricos, médios, pobres e miseráveis.

Há de se observar que todas essas diversidades, biológica, cultural e socioeconômica, ao invés de constituírem-se em fontes coletivas de desenvolvimento e enriquecimento mútuos, transformaram-se em causas de problemas, conflitos e violências em escala mundial.

No entanto, os preconceitos são universais e existem em todas as culturas e sociedades humanas. A grave questão que se coloca é quando eles são transformados em armas ideológicas para justificar a violência, a dominação, a exploração e a exclusão dos outros. Neste caso, eles se transformam em ideologias ao serviço da dominação e exploração e assumem uma função política indiscutível.

As diferenças constituem uma fonte insubstituível de enriquecimento; a própria sobrevivência da humanidade está nas diferenças e na diversidade delas resultante.

Nas grandes calamidades naturais - doenças pandêmicas como a febre amarela e a peste -, muitos morreram, como estão morrendo hoje na pandemia da Covid-19, mas outros sobreviveram graças às diferenças imunológicas. Todas as epidemias letais exterminariam grupos inteiros se não fosse a diferença imunológica. A estética do corpo humano 
é um valor em todas as sociedades. As pessoas consideradas ou que se consideram mais bonitas do que as outras têm consciência de sua beleza porque se comparam às outras pessoas consideradas feias nos cânones de beleza de cada sociedade; os homens se imbuíram de sua superioridade machista porque as mulheres existem; as pessoas mais altas ou esbeltas se acham mais bonitas porque existem pessoas baixas e gordas; os velhos se acham mais sábios porque existem jovens; os ricos se acham melhor sucedidos porque as sociedades produziram pobreza e miséria.

A grande questão que se coloca é a de que não temos a igualdade de oportunidades e de direitos por causa das diferenças. Quase todas as constituições e leis no mundo todo defendem o princípio de que "perante a lei, somos todos iguais e que todos os seres humanos nascem livres e iguais em direitos". Teórica e formalmente sim, mas de fato e materialmente não. Os 30 artigos que constituem a Declaração Universal dos Direitos Humanos não são integralmente respeitados por todos os países do mundo; o que é um grande paradoxo, já que os países que se dizem democráticos continuam a produzir e a vender armas, mesmo sabendo que elas destroem vidas humanas, colocando o lucro e a riqueza à frente do ser humano e do "outro" diferente. Em vez de a economia estar ao serviço da maioria da população, ela está sendo colocada ao serviço de uma minoria dominante. Esta lógica de pensamento se repete no século XXI em alguns países do mundo capitalista diante das ameaças às vidas causadas pela Covid-19.

Os preconceitos e as ideologias deles resultantes têm a diferença como matéria prima: diferença de sexo ou de gênero desemboca no machismo; diferença de nacionalidade, em 
nacionalismo; diferença de etnia, em etnicismo; diferença de vida sexual entre pessoas do mesmo sexo, em homofobismo, etc., e todos se transformam em justificação e legitimação da exclusão e da desigualdade entre seres e grupos humanos.

Como fazer para lutar contra esses "ismos" e suas consequências? Todos os países conscientes que querem mudar trilharam três caminhos complementares: as leis, as políticas públicas e a educação. As leis devem reprimir e punir os atos discriminatórios baseados nas diferenças, porque não basta dizer que, perante as leis, somos iguais. Por isso, qualquer ato de discriminação comprovado é, na Constituição brasileira de 1988, um crime inafiançável e sujeito à reclusão. Além das leis, o Estado deva implementar estratégias e políticas de promoção da igualdade dos discriminados, visando sua inclusão e a redução das desigualdades.

As duas ações, embora importantes, não são suficientes, pois é preciso transformar o Ser através do processo de formação da cidadania, numa visão pluralista. Como bem disse Nelson Mandela, nenhuma criança no mundo nasceu odiando as outras crianças dela diferentes. São pessoas adultas que, através dos processos educativos, introjetaram ideias e comportamentos racistas, sexistas, machistas e homofóbicos nas crianças. Só a educação, acreditam, teria o poder de desconstruir os monstros que criou e formar novos diferentes.

Que tipo de educação precisamos hoje? Uma educação que forma novos cidadãos com base na valorização da riqueza de nossas diferenças e de nossa diversidade em todos os sentidos; uma educação construída a partir de novas ferramentas pedagógicas antirracistas, antimachistas, anti-homofóbicas, etc. Enfim, uma educação que respeita o outro diferente e 
todas as diferenças que constituem a diversidade biológica, cultural, de gênero ou de sexo, de religião, etc.

As leis 10.639/03 e 11.645/08, que obrigam o ensino da história e da cultura dos negros e povos indígenas e a história e cultura da África na escola brasileira, visam justamente a construção de uma escola inclusiva e não discriminatória. Isto não significa que a história da Europa e da Ásia deve ser substituída, mas sim que a história do Brasil deve incluir outras raízes formadoras em vez de ser empobrecida por uma única história e cultura consideradas como superiores ou melhor que as outras. A não inclusão da história dos outros os destrói, os diminui e anula sua autoestima e sua identidade.

Mesmo na hipótese de que "somos todos mestiços", pois a "pureza" é um mito, nossa mestiçagem não caiu do céu. Suas origens precisam ser inventariadas, analisadas e ensinadas no processo de formação da cidadania brasileira. Essas raízes não são somente europeias. São também indígenas, africanas, asiáticas, ciganas, etc. Todas contribuíram de uma maneira ou de outra no processo de formação e construção do povo e da nação brasileira.

O que este texto de apresentação teria a ver com o livro "Fiç̧ões do ser", da autoria de Kauan Santos Almeida? Retrucariam alguns leitores? Justamente porque $\mathrm{O}$ autor deste livro se debruça de maneira construcionista e não essencialista sobre uma das questões que atormentam as sociedades humanas por causa das diferenças, tanto biológicas quanto culturais e sociais. Mas ele não se afoga nas águas profundas do Atlântico através do qual seus ancestrais foram deportados para os países da América. Dotado de uma dupla consciência como negro e como homossexual, ou respeitando suas próprias 
palavras, como negro e como "bicha", ele nada com facilidade nessas águas profundas em busca de compreensão e contribuição na luta contra essa dupla discriminação de raça e sexo. Depois de uma longa retórica com base nas leituras de grandes intelectuais brancos, negros e outros que discursaram sobre o assunto, ele realiza uma rica pesquisa de campo baseada na observação participante, ou melhor, na participação observante, através de uma proposta de intervenção para introduzir, no Colégio Leonilson, alguma mudança no Currículo, para quebrar o silêncio, o medo, a violência em torno dos preconceitos e das práticas racistas e homofóbicas contra "s negros, partindo da convicção de que é através da educação, que começa no lar e continua na escola, que se forma indivíduos racistas, sexistas e machistas. Só através da educação que se pode desconstruir os monstros racistas e sexistas e construir novos cidadãos. Como fazer se os livros didáticos são repletos de preconceitos e se os próprios educadores foram formados no modelo de educação eurocêntrico e machista? Como fazer se o currículo vigente de educação é construído numa perspectiva monolítica, que não abre debate sobre as questões cadentes da sociedade e onde se pensa que formar é reproduzir os conteúdos congelados nos livros ditos científicos? A proposta que ele introduz, visando a sensibilização, a conscientização e a politização, de trabalhar a questão dos preconceitos contra homossexuais negros através de uma série de aulas-oficina, algumas até sob formas de festas de confraternização entre os semelhantes e os diferentes, é inovadora. É uma espécie de performance onde se dialoga, em grupos, entre semelhantes e diferentes, sobre suas vidas e a sociedade, em vez de uma educação individual, onde se pensa resolver sozinho as questões da sociedade. Neste texto, escrito numa linguagem ao mesmo tempo filosófica e poética, que 
envolve afetivamente seus leitores, o autor interage e se expõe numa postura que a grande escritora Conceição Evaristo qualifica de escrevivência. Seu olhar de dentro dialoga certamente com o olhar de fora, numa relação dialógica em busca da libertação do pensamento colonizado e numa perspectiva decolonial.

Kabengele Munanga

Setembro de 2020 



\section{1}

\section{A você, leitora!}

Quando, em agosto de 2017, recebi a notícia da minha aprovação no Mestrado Profissional ${ }^{1}$ em Ensino e Relações Étnico-Raciais da Universidade Federal do Sul da Bahia, por um momento fiquei atônito, afinal, seria um acontecimento único e importante tanto na minha vida quanto na da minha família, pois, diferente de toda a trajetória da minha família, eu teria a oportunidade de ser alçado à titulação de mestre, mesmo não sabendo muito bem o significado disso.

Eu já vinha de um percurso que me inseriu nos movimentos negros e LGBTs, o que fez com que eu tivesse contato com literaturas mais específicas e a consciência do meu corpo em alguns espaços, principalmente no que se refere às questões raciais. Foi este mesmo percurso militante que me lançou a reflexões sobre o enclausuramento do meu corpo às marcas corpóreas da escravidão, assim como a dupla consciência, sobre a qual teorizaram Du Bois e Paul Gilroy, de encontrar-me seccionado entre a raça e todas as outras interpelações que transcendem o campo racial, como é o caso da sexualidade.
1. O presente texto foi utilizado como trabalho de conclusão do Mestrado Profissional em Relações ÉtnicoRaciais da Universidade Federal do Sul da Bahia. Por isto, optouse por deixar esse rastro informativo para o conhecimento da leitora. 
Se a brasilidade evoca uma mistura festiva das três raças (branca, negra e indígena) formando um contínuo miscigenado, não fazia sentido autodeclarar-se negro no interior de uma nação onde a sua cor não é lida enquanto mácula. Mas você sabe que isso é mentira, não é? Porém, com 6 anos, como eu iria saber?! Adotei, assim como muitos, uma forma-mulata que é expressa no negro-do-sorriso-bonito que adora o seu país tropical e abençoado por Deus, mas que, assim como muitas outras negras, vive encapsulado em favelas da capital paulistana.

E aqui quero começar a conversar diretamente com você. Você que lerá este texto e que de alguma forma terá acesso a mim e às minhas vertigens. Embora pareça que eu esteja a representar algum grupo social, eu não estou. Produzo só a mim mesmo, não por egoísmo, mas por impossibilidade teórica de estender o caos e transformar força em forma.

As pessoas, não sei se você também, têm muita curiosidade em saber como são as vidas das pessoas negras, como são as vidas das pessoas homossexuais, no limite, como são as vidas daquelas que se diferem da forma branca, cis-heterossexual, masculina, cristã e burguesa. Percebo que soa quase como um fetiche para elas. Em muitas mesas que participo e convites que recebo, há uma nota de rodapé invisível em que diz "divida com o mundo as dores de ser bicha e preta. Fale sobre suas vivências, sobre as violências sofridas".

Sempre que percebo esta nota de rodapé, sinto uma imensa tristeza, pois, normalmente são pessoas inteligentes que querem saber qual a experiência de um corpo negro 
e bicha. Estas perguntas e convites carregam um forte teor narcísico e nos querem como macacos, para alegrar a plateia, ou como dramáticos, para fazê-la chorar. Ao final, uma interlocutora se dirige a todas e diz "precisamos respeitar negros, mulheres, indígenas e LGBT's, pois são humanas como nós". Mas, ao que me parece, esta humanidade só nos é ofertada momentaneamente enquanto sangramos falando do "nosso" difícil passado de luta e sofrimento.

No limite, não é respeito, mas sim piedade. Daí que algumas sempre nos dirigem as falas em tom caridoso. É triste, você não acha? Como posso falar sobre escravidão ou significado de privilégio branco, quando a minha interlocutora encarna todas as heranças de pilhagem e violência e parece não se dar conta disso? Ou, quando acontece de se sentir culpada e assumir publicamente o seu privilégio, me pergunto, às vezes, o que querem que façamos com isso? As raças, os gêneros e as sexualidades são produzidas ainda como naturais, logo, suas descrições acompanham sentidos que tentam a todo instante nos fixar. Mas, as negras e a raça, assim como as homossexualidades e a sexualidade, nunca foram elementos fixos.

Mas a violência que constitui o racismo e a homofobia é consequência inalienável desta necessidade de identificar, de produzir o sujeito negro, assim como o homossexual, no interior das mesmas arenas hierárquicas de colonização e pilhagem. Essas identificações são estratos hierárquicos que conferem inteligibilidade à vida social a partir do reconhecimento. No Brasil, por exemplo, são estas crenças nos estratos hierarquizados que tentam definir quem pode cagar em um shopping e quem não pode 
2. Disponível em: http://sportv. globo.com/site/ programas/ta-na-area/ noticia/2017/07/ richarlyson-sobrehomofobia-e-vazio-taopequeno-para-aquiloque-eu-sou.html
(SCHUCMAN, 2012), assim como quem é afeminado de-

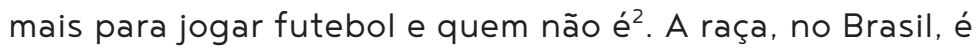
menos uma questão de árvore genética do que uma questão privilegiada à brancura (SOUZA, 1983) - brancura que ultrapassa os significados do ser branco enquanto indivíduo e se estabelece mais como uma rede discursiva de poder-saber.

E é esta crença na brancura, coisa que você já deva ter percebido, que faz com que pessoas, para além do cabelo, nariz, cor de pele, sejam levadas a acreditar na ficção da branquitude, assim como outras são levadas à da negritude, assim como outras são levadas à da heterossexualidade, etc. Mas, a diferença aqui reside nos significados atribuídos a cada uma dessas construções modernas. Elevadas à representação, caem em uma espiral de teias discursivas presas a aparatos estereotipados. A brancura, por exemplo, nunca esteve relacionada negativamente à pilhagem, a violências, guetificações e encarceramento em massa; quando sujeitos brancos experimentam essas condições, é, pois, a extensão daquilo que Mbembe (2018) teorizou como o Devir-Negro do mundo.

Mas, o que leva os sujeitos a se enxergarem como brancos ou negros? Eu, de fato, não tenho respostas a esta questão, mas - concordo com Ta-Nehisi Coates (2015) que não foram atividades como "degustações de vinhos e sorvetes" - sabemos que a brancura se alçou a tal posição através das violências, dos mecanismos extrativistas de vida e terra, pelo açoite às diferenças e a negação do outro enquanto governantes de seus corpos.

Mas, como muitas de nós sabemos, o Brasil nunca pensou na condição do homem e da mulher escravizados 
no pós-abolição; aliás, o Brasil é excepcional em apagar as memórias da sua própria violência. Caso você duvide, peço rapidamente que pare esta leitura e faça uma pesquisa no Google sobre em que transformaram os pavilhões do Carandiru, onde 111 homens foram mortos. E sim, é mais fácil viver com a virtuosidade da ignorância e brincar nos jardins do Carandiru do que ter que olhar para aquele prédio e recordar da força genocida do nosso país tropical, que trucida corpos negros por "engano" ou por esporte.

Porém, acredito, talvez esteja enganado, que muitas de nós não participamos ativamente dos luxos que produzimos e isto pode nos irromper em um grande ódio contra eles. E novamente habitamos as fronteiras ficcionais polarizadas que dividem eles de nós, mas é justamente na fronteira que vivemos, ou, como falo por mim, que vivo. Recentemente, enquanto escrevia o que viria a ser a primeira seção da dissertação, fui interrompido, pois, no bairro onde moro, dois homens negros foram mortos pela polícia ${ }^{3}$ e duas outras pessoas ficaram feridas. Quase que instantaneamente recebi as fotos pelo WhatsApp, assim como áudios dos tiros.

Um dia depois, um outro homem negro foi morto ${ }^{4}$, em plena luz do dia, enquanto dirigia uma lotação; as notícias diziam que ele teria sido confundido com um traficante. Quando saí da periferia de São Paulo para a Bahia, pensei que veria menos casos de mortes, mas me enganei. Eu aprendi muito cedo que a polícia tem autoridade para destruir corpos negros, seja por engano ou por "proteção aos cidadãos de bem". Eu vi a polícia atirar em amigos meus em frente à escola, vi policiais passando com suas viaturas e atirando em sujeitos negros, fugi de policiais que atiravam loucamente enquanto brincávamos próximos à valeta
3. Disponível em: https://radar64. com/noticia/ identificado-segundomorto-em-tiroteio-nocambolo_39758.html

4. Disponível em: https://radar64.com/ noticia/motorista-delotacao-e-morto-amigofica-ferido_39784.html 
da rua 3, na favela do Pantanal, no Itaim Paulista, e tive policiais apontando suas armas em direção à minha cabeça, em revistas noturnas e em manifestações por direitos básicos, como o de estudar.

Assim, aprendi à força como um corpo negro deve se comportar em algumas situações, é algo da ordem de saber manter a medida certa, caso deslize para mais ou menos, qualquer ação é perigosa: uma reação extrema a uma abordagem, perigo latente; sozinho em ruas escuras, perigo latente; marcar de encontrar amigas/os na esquina, perigo latente; estar com um amigo branco no ponto de ônibus à noite, perigo latente. E o mais aterrorizador é que estas experiências não estão distantes daquelas relatadas por outros corpos negros, pobres e jovens. Dessa forma, as dicas de como "escapar" ao potencial de destruição destas máquinas públicas de segurança à brancura são passadas quase como uma receita ancestral: leve seus documentos, não reaja, responda somente o necessário.

Mais tarde, percebi que muitos policiais, para não dizer todos que atuavam no bairro onde eu morava, eram "irmãos", isto é, outros homens negros. Mas, se você está seduzido à narrativa do poder, a coisa é outra e o buraco não é mais embaixo, é em locais letais. Não sei se você tem ideia do que é esta experiência, mas, sinceramente, espero que não; ela talvez seja um dos contatos mais dolorosos com a cicatriz coIonial. Ela marca nossos corpos com toda a herança escravocrata. A experiência do racismo é tamanha que possivelmente nos faça sangrar sorrindo, é da ordem do visceral, pois sempre culmina no corpo, ainda que você só veja gráficos e tabelas, números e estatísticas, ciências humanas e artes. 
Quando Foucault (2013) escreveu que estava condenado a viver no próprio corpo, ele não tinha ideia do quanto iria me afetar essa sua leitura, assim como quando Fanon (2008, p. 126) escreveu:

O preto é um brinquedo nas mãos do branco; então, para romper este círculo infernal, ele explode. Impossível ir ao cinema sem me encontrar. Espero por mim. No intervalo, antes do filme, espero por mim. Aqueles que estão diante de mim me olham, me espionam, me esperam.

Eu sei, Fanon e Foucault não escreveram para mim, mas gosto de pensar que sim, assim crio uma afinidade poética com a escrita. Durante a minha vida, tenho lutado para encontrar a melhor maneira de viver dentro de um corpo negro - ainda não comecei a falar sobre a sexualidade.

Há algum tempo decidi me desfazer de um vocabulário para falar sobre raças, gêneros e sexualidades ${ }^{5}$. Rejeitar um vocabulário é uma quebra no meu percurso formativo como intelectual, pois passei a rejeitar simplificações que, não raramente, caem em essencialismos ou em discursos revestidos de uma aura cientificada que nos faz jogar o jogo do racismo científico e que nos coloca na ideia moderna sobre corpos negros. Isto, para muitos colegas de militância, soou e ainda soa como um embranquecimento, uma ocidentalização do pensamento, mas, acredito eu, que seja uma fuga às fórmulas mágicas que prometem a emancipação.

A minha atual ideia de liberdade gira em torno de viver livremente dentro do meu corpo negro e bicha, ainda que eu não tenha uma linguagem adequada para expressar
5. Refiro-me a um vocabulário expresso em uma ontologia da representação. 
como. Durante minha infância, a linguagem preponderante na minha comunidade era a do medo. Fomos forjados no e pelo medo a ponto de uma descorporização de alguns. O medo era uma expressão também. Garotos com suas posturas eretas pelo medo; calças baixas deixando à mostra suas cuecas por medo; bonés com suas abas retas de medo; um jeito meio agressivo de mascar os chicletes do medo; uma forma de impor o medo a outros por simplesmente sentirmos medo.

Tudo isso formava um aglomerado de signos e seus sentidos que, ao inspirarem medo ao outro, causava uma sensação de poder local. Era esta impressão de poder que fazia com que alguns garotos pudessem se sobressair a outros, o medo era, no final, uma grande máscara para esconder como nossos rostos continham marcas coloniais. As máscaras tinham, também, seu contraefeito; ao utilizá-las estaríamos suscetíveis à violência, às armas de fogo que outros meninos levavam para a escola e às drogas que eram vendidas por sujeitos de toucas escuras que ficavam encostados nos muros, mas sem utilizar máscaras. Possivelmente, nossa nudez seria castigada pelo efeito das políticas de segurança pública.

A máscara racial utilizada por homens negros é muitas vezes revestida por um componente da masculinidade cis heterossexual que emula comportamentos patriarcais de senhores brancos contra mulheres, na vasta maioria negras, e qualquer dissidência sexual ou corpos desobedientes aos gêneros. Estes homens são educados a partir da pedagogia da rua. E aqui abro um espaço para dizer como 
é difícil para mim refletir sobre a violência e, ainda mais, sobre aqueles que me violentam, mas continuemos. A pedagogia da rua é a educação em força - não em forma -, nos mais distintos lugares. É a empiria do aprendizado.

É na rua que aprendemos que as mortes de nossos amigos não são casos de injustiça, mas, dolorosamente, é o cumprimento da lei da brancura que exige segurança. Na rua também aprendemos a confrontar o mito da irmandade e outros mitos negros que são tão belos quanto irreais. A experiência da rua faz com que cada acontecimento seja um risco, é viver o abismo: jovens negras grávidas, filhos que crescem sem a figura paterna, saltar sacos pretos com corpos negros para ir à escola e ver amigos de infância matarem uns aos outros em nome da lei da masculinidade.

Contudo, a experiência mais avassaladora, no meu caso, foi a de escapar de jovens que aprenderam a canalizar a linguagem do medo em raiva. Esta aprendizagem é a que seduz muitos homens brancos e negros ao poder, a ponto de um garoto de 13 anos, ao se sentir humilhado após uma partida de videogame, ir à sua casa, pegar uma arma e dar três tiros nas costas de um de seus colegas. $O$ atirador se chamava Willian, estudava com meu irmão, a vítima era apelidada como Galego.

Estes homens e meninos que aprenderam a potência de seus corpos se divertiam às custas de meninos como eu: viados; e, ao mesmo tempo, me ensinaram que, se eu quisesse sobreviver, teria que aprender o ato do disfarce, teria que minimamente emular aquilo que eles faziam com maestria tamanha, a ponto de terem seus nomes cravados 
nos muros com mensagens de saudade após suas mortes. Uma bicha deveria aprender seu lugar. Assim, memorizei horários e locais dos bairros em que poderia passar. Caso fosse surpreendido por um ou outro, eu deveria enfiar minhas mãos nos bolsos e acenar com a cabeça "iaê"; qualquer suspeita sobre a minha sexualidade era perigosa.

Depois de um tempo, a gente aprende até mesmo o cheiro e o sabor. Se eu esquecesse, como algumas vezes aconteceu, teria minha punição. Garotos jovens jogavam pedras, havia a constante ameaça de apanhar no portão da escola e a experiência máxima da humilhação para uma criança que ainda não sabia direito o que era ser viado, mas, pelo jeito que ouvia outras pessoas falarem, sabia que não era uma coisa boa, pois aqueles que assim te chamam, o fazem para constrangê-lo.

A experiência da sexualidade dissidente em um corpo negro é de uma agudeza que faz qualquer palavra vacilar, qualquer gesto ser um flagelo. Medo do seu pai, da sua mãe e dos seus amigos que desconfiam, mas não têm certeza, visto que alguns se parecem mais com "homens de verdade" que outros. E isso de me saber viado me custou a maior parte do pensamento do caminho de casa à escola.

E aqui chego à escola, o meu local de pesquisa. Ta-Nehisi Coates (2015, p. 32) diz que "se você não compreender as ruas, terá desistido do seu corpo agora. Mas se não compreender as escolas, desistirá do seu corpo depois". A escola foi sempre tida, na concepção dos meus pais, como a única possibilidade de ter um futuro diferente do deles. 
Meu pai é um pedreiro que cursou até a terceira série do Ensino Fundamental, já minha mãe é uma costureira e diarista que possui o Ensino Médio incompleto.

A escola se apresenta, então, para muitas famílias negras e empobrecidas, como um local que possibilita a ascensão social, assim como produz uma distinção social entre aqueles que estão dentro e fora. Minha mãe sempre exigiu um grau de excelência nas notas tanto minhas quanto nas do meu irmão. Era uma equação muito simples: "nós não tivemos estas oportunidades, vocês têm, então não vamos deixar vocês desistirem". A não desistência da escola nos custou dores, fomes e bicos como catadores de latinha, cobre e papelão nas horas vagas, para ajudar na compra de materiais escolares e outras coisas.

O que eu não imaginava é que, no intercurso dos meus anos na escola, eu constituiria um terceiro olho, como um elemento de proteção às investidas coloniais, um terceiro olho que produzia processos de desidentificações com os quais eu questionava muitas das coisas que me eram passadas. Nas escolas em que passei, construí grandes laços de amizades. Pensando agora, foram os melhores e os piores anos da minha vida, talvez, ambos ao mesmo tempo.

Ao olhar para o passado, percebo redes de subalternização, de submissão e de produção de uma miséria racial e sexual que acontecia em muitos espaços da escola, mas, também, as contestações e subversões que produzíamos. Foi na escola que percebi como eu parecia mais forte, alegre e, paradoxalmente, mais vulnerável ao lado de amigos 
gays. Tínhamos fortes laços e, ainda que não nos identificássemos publicamente como bichas, sabíamos que fluxos outros nos atravessavam, distintos de uma pretensa heterossexualidade "natural" disposta nas imagens familiares de mamãe, papai e filhinhas/os que nos incitavam a ser.

Não era questão de somente ser negro e gay, como se fosse um cálculo somatório, era outra coisa, estávamos em outra posição. Em detrimento da soma, era potência e afronte, como só fui notar muitos anos depois. Assim, a partir da escola, aquele espaço da rua que eu entendia como perigoso para mim foi vagarosamente se transformando em outra paisagem, da alegria, do encontro e da reinvenção, diferente da minha casa, que, por medo de me "assumir" para os meus pais, foi se tornando cada vez mais violenta e silenciosa. Hoje noto que, ao enxergar somente a violência das ruas, estamos criminalizando um espaço público e que a violência que nelas vemos é, talvez, uma forma de nos domesticar na intimidade violenta de alguns lares.

E eu só pude contemplar a fascinante vivacidade da rua a partir da escola. Nela, também, tive encontros alegres com professoras/es que nos lançavam para outros lugares distantes da violência e das dores. No Ensino Médio, tive uma professora de nome Carmen, que, ao notar meus trejeitos afeminados e o grupo com quem eu andava, me deu o livro Bom-Crioulo, do Adolfo Caminha. Eu sei, embora haja muitas críticas que se possa fazer sobre o livro, na época me marcou a representação de Amaro, e eu nunca havia lido nada que contasse uma história de um homem negro e gay.

Assim, aprendi a escola, apanhei bastante até que soubesse criar estratégias para viver minhas sexualidades 
nos intercursos dos seus espaços. Eu sei, estamos saturados das descrições que apontam para a escola como um lugar pouco hospitaleiro às diferenças; e confesso, não tenho a menor vontade de reproduzir estas histórias, por isso traçarei devanei(gr)os de resistências a partir daqui.

Embora a coisa de se dizer bicha e preta sempre seja lida como uma tragédia social, alvo das discriminações mais diversas, é desde este local que enuncio as possibilidades de inventar narrativas alterizadas. Recontar nossas histórias negras e dissidentes sexuais para erigir cuírlombos, conceito que tomo de empréstimo da Tatiana Nascimento (2018). Deste local que é uma paisagem em movimento, produzimos ferramentas conceituais que desmantelam o que, durante muito tempo, nas comunidades negras, se costumou chamar de "praga branca", como se a negritude fosse uma experiência que se afirmasse unicamente na heterossexualidade.

Por isso, digo a você, leitora, que embora a constituição colonial de nossas instituições esteja pronta para nos esmagar, elas nunca serão grandes o suficiente para estrangular nossa capacidade de imaginar, de criar, de produzir bonitezas para além das visualidades estanques que nos acostumaram. O banzo não é capaz de deter os fluxos das diferenças dos corpos que, lançados no oceano, nos molham os pés à praia.

Eu tive muitas dúvidas quanto à linguagem com que escrevo, tenho medo, confesso, de parecer hermético, mas, ao mesmo tempo, não preciso me justificar. Acho que escrever seja isso, me impulsionar pelas agonias e alegrias de uma grande aventura dissonante e incerta, por isso optei por uma linguagem ensaística que beira a heresia de pensar as negritudes dissidentes sexuais como rasgos que não 
explicam, mas intensificam os acontecimentos dos nossos corpos. Se a vida é vertiginosa e incerta, por que a escrita não o seria também?

Assim, este texto foi dividido em seções-paisagens, cujos movimentos se encarregam da produção de um jeito de ver a partir das (des)costuras das próprias linhas grafadas no currículo, onde se tem certo sentido de movimento, mas não necessariamente o seu ponto de chegada. Dessa forma, são paisagens constituídas pelos trânsitos e pelas cenas, onde ficções são inscritas como possibilidades de criar mundos nos currículos.

Em Pela metade: notas de um quase início, há a imersão no campo teórico-metodológico do estudo, apresentando os principais conceitos desdobrados durante as análises, assim como os fios que conduziram (des)caminhos durante os itinerários. Em "Todas nós nascemos nus e o resto é drag": devir-bicha no currículo, constituo, a partir de duas cenas, um mapa aberto das linhas produzidas pelos movimentos de corpos estudantis. Tais movimentos, que se acoplam e se rasgam, produzem agenciamentos que deslocam corpos racializados e dissidentes sexuais da lógica identitária da representação ensaiada pelo currículo. Utilizo como suporte a filosofia da diferença de Deleuze e Guattari para operar devires que possibilitam pensar as existências escolares em outras invenções. Parto do argumento da visibilidade enquanto local de ambivalência para corpos bichas. Em "Por que tu me chamas se não me conheces?": devir-negro em um currículo, desdobro os argumentos já iniciados na paisagem anterior; contudo, dessa vez investigo outras possibilidades de existência e resis- 
tência, assim como a linha de fuga como criação de locais habitáveis para corporalidades abjetas. Antes de dar prosseguimento ao que será a última seção-paisagem, cabe um esclarecimento do motivo de ter separado em seções-paisagens distintas os devires bicha e negro.

Durante o percurso no Colégio Leonilson, observei que, embora não exista hierarquia de opressão, ela incide e marca alguns corpos em diferentes dimensões e intensidades. Daí que algumas alunas negras e gays, quando entrevistadas, observavam mais as facetas de uma homofobia em detrimento do racismo, ou vice-versa. Com isso, não penso que um seja mais ou menos relevante, em critério de análise, que outro, nem sequer julgo que não possa haver uma experiência que se ensaie como um devir-bicha-preta - que foi meu primeiro impulso de escrita, a fim de singularizar tais linhas. O que fiz foi uma tentativa de manter a minha fidedignidade com os relatos, os desejos expressos pelas estudantes e com o próprio campo. Dessa forma, não desejo, assim, reafirmar o padrão descrito em que corpos racializados são tidos enquanto heterossexuais; e corpos dissidentes como brancos. Ao contrário, as existências de corpos negros e dissidentes residem em singularidades que implicam outras maneiras de ver e enunciar sobre o mundo, assim como faz esta bicha preta que vos escreve. 
Como recolher as cinzas

das fendas abertas pelos olhos que se dilatam de pânico?

Dos pulsos quebrados pelz envergadure nio cimentad. de meu corpo?

Houve um tempo em que os fluxos da vidz eram tolhidos em mim, por aquilo que me deram:

O Ódio a minha pele

o REPUDDIO ho mEU DESEJO

Grandes grades engerrujadas pelas lendas da náo bospitzUm eu e um outro que se conjundiam

lidede

No banzo tícilo do querto, quentas bichas pretas jí pensarem no peso de suz cor e nz cor da suz sexuzlidade

e aprenderam que o amor é uma música rípida demzis parz dençzar a dois ou mais?

Aliźs, quel dicionzivio negro comporta a flexio do ver. bo emer?

$23 / 06 / 18$

36 
豆 



\section{2}

\section{Pela metade: notas de um quase início}

Um grande pátio se abre à visão, são oito horas da manhã de uma terça-feira. Uma grama verde ainda molhada pela neblina forra o chão próximo à parede branca e alguns bancos. As janelas de batentes azuis dão uma continuidade harmônica à paisagem. A composição se forma no decorrer dos passos que ficcionalizam o ambiente. Cartazes nas paredes, alguns com manifestações de direito ao corpo: girl power, black is beautiful. Corredores se formam, o corpo está ao meio, claustrofobicamente tragado por entre portas azuis que dão para linhas que compõem experiências. Grandes quadros que resguardam memórias do que ali se passou: bacias hidrográficas, equações de segundo grau, regra de três. De repente, ruídos escapam de direções distintas, entro em uma sala retangular. Uma mesa à frente de quarenta carteiras, janelas com seus vidros quebrados e uma frase pichada na parede: quero ir embora.

Na sala retangular, composta por mesas e cadeiras, ouço sibilos e estertores de corpos que agonizam fechados, eles me olham lateralmente, mas não consigo distingui-los, embora haja claridade na sala. Seus movimentos são sinuosos 
e por vezes se embaraçam como se estivessem engalfinhados em uma briga, são fricções corpóreas do ininteligível, eles se penetram, se modificam, separam-se e novamente formam uma unidade. Uma batalha que ora resiste ora se entrega. De repente, os corpos se multiplicam incansavelmente, ocupam todos os espaços da sala. Uns gritam, outros assistem desinteressados às fagulhas resultantes dos encontros. Mas já não é uma briga, é puro prazer de intensidades, é produção de desejo sem gozo, são experiências, linhas de fuga, ética fora da moralidade. Dos corpos engalfinhados, não saem sangue, mas fluxos que atravessam toda a sala, escorrem pelos corredores, molham as gramas, alcançam a quadra e são usados como tintas para pichar o banheiro. Alguns corpos pisam nos fluxos, mas não se importam, não são molhados pela substância estranha, logo, limpam seus pés e caminham rumo às tarefas ordinárias do cotidiano.

Eu me sinto nu em meio ao cenário, corro pelos corredores claustrofóbicos, molho-me nos fluxos que escorrem da parede ao chão, o meu desejo que se apresenta imanente à situação é participar da cena e dela me afetar a ponto de sentir todas as sensações possíveis, me incorporar aos gritos e às linhas que se multiplicam. Pelo que me recordo, e assim me traio ao traduzir, era possível sentir cheiros e sabores, me assustar e surpreender com os acontecimentos. Meus sentidos estavam à flor da pele, mas nenhum se sobrepunha ao outro: olfato e visão, audição e tato possuíam cada um a sua particularidade, sem que isso fosse hierarquizado. Ao me dar conta de que não estava sozinho, percebi que ao meu lado estavam Deleuze \& Guattari, Michel Foucault, Achille Mbembe, Nilma Lino Gomes, Elizabeth Macedo, Sandra M. 
Corazza, Petronilha Gonçalves e Silva, Homi Bhabha, Frantz Fanon, Linn da Quebrada, bell hooks e outras ainda não identificáveis. Elas me sopravam coisas ao ouvido, palavras que eu ainda não estava pronto para ouvir, traçavam geografias da diferença ${ }^{b}$ e incitavam à cartografia dos corpos.

Havia a violência do pensamento, a ambivalência das posições que se deslocavam entre conversas banais sobre o cinema e o sonho. Os encontros eram sempre o meio do caminho (não o caminho do meio), nunca se situavam em um início e às vezes jamais chegavam a um fim, eram cortes, fugas, subterfúgios e sabotagens. Tudo estava na ordem do irrefreável.

E assim, é isso que se segue nesta composição. Paredes brancas tingidas por grossas letras coloridas que incendeiam qualquer tentativa de coerência. Linhas que coreografam no currículo os vestígios e sombras das existências. Um palco por trás de cortinas que jamais se levantarão. Obviamente, muitas cenas não penetraram suficientemente à escrita, não pela sua suposta profundidade, pelo caráter laminar de sua agudeza, mas pela impossibilidade de captura da sua velocidade que instaura cortes no tempo e no espaço. O que se segue são intensidades na tentativa de constelar o currículo, de fazê-lo ultrapassar os limites da representação, de fazê-lo pulsante como mãos que sacodem dados para jamais abolir o acaso.

Não há sequenciamento, encadeamento retilíneo das operações casuais que meu corpo experienciou, por favor, não espere por isso. Não há, sequer, tentativa de representar o que durante seis meses se passou na escola, há apenas
6. A geografia da diferença constitui uma relação entre "a filosofia deleuziana e os pensamentos filosóficos, científicos e artísticos [...] mais como uma geografia do que como uma história, isto é, o fato de ela considerar o pensamento não por intermédio de uma dimensão histórica linear e progressiva, mas privilegiando a constituição de espaços, de tipos não apenas heterogêneos, mas sobretudo antagônicos" (MACHADO, 2010 n.p.) 
7. "Os perceptos não mais são percepções, são independentes do estado daqueles que os experimentam; os afectos não são mais sentimentos ou afecções, transbordam a força daqueles que são atravessados por eles. As sensações, perceptos e afectos, são seres que valem por si mesmos e excedem qualquer vivido. Existem na ausência do homem, podemos dizer, porque o homem, tal como ele é fixado na pedra, sobre a tela ou ao longo das palavras; é ele próprio um composto de perceptos e afectos. A obra de arte é um ser de sensação, e nada mais: ela existe em si" (DELEUZE; GUATTARI, 1992, p. 213, grifo dos autores). $f(r)$ icções do encontro de corpos diferentes que produzem agenciamentos, realizam montagens e bricolagens formando rizomas. São devires que instauram forças, velocidades e lentidões sobre moléculas esparsas ao campo que ganham traços, linhas, palavras, imagens e se abrem a outras "dimensões numa multiplicidade que muda necessariamente de natureza à medida que ela aumenta suas conexões" (DELEUZE; GUATTARI, 2000, p. 16).

Nesse sentido, é através do corpo que a escrita ganha matizes de existência, por isso não há uma forma-escrita desidentificada, embora haja uma catalisação de afectos obtida via perceptos ${ }^{7}$ quanto aos atravessamentos do campo, pois o acontecimento está fora do sujeito e constitui linhas a partir das experiências daquilo que é outro, uma alteridade. Contudo, sendo o "meu" corpo o locus, escrevo com o que dele penso possuir: mãos, pernas, sistema nervoso central e periférico, pulmões, coração, fígado e rins, olhos e orelhas, boca e cabelo. Mas, não só, sou um corpo contaminado pelos fluxos do campo, assim, outros passam por e através de mim, eu os devoro e sou por eles devorado, transformo, crio e recrio a partir das suas forças e lanço a escrita para outros lugares do currículo.

Mas se este texto já se inicia pela metade e não almeja um fim, dissipa-se em meio às linhas, personagens estranhas, vozes hostis, rostos configurados por uma lógica própria, tortuosas figuras da monstruosidade que assombram o currículo, tal como as personagens das fotografias de Diane Arbus $^{8}$ causam espanto aos que se julgam "normais". São discursos juvenis, entendendo aqui que a própria juventude se constitui enquanto uma ficção do currículo, que se sobrepõem a outras 
ficções, que criam lugares de resistência e conformação à engenharia curricular (VEIGA-NETO, 2002).

Garotas e garotos que se beijam na escola e causam rebuliços ao sentido disciplinar estabelecido por regras e códigos de condutas. Meninas que cantam e dançam funks com letras "imorais" aos padrões das mulheres belas, recatadas e do lar. A transformação do sentido do uniforme em roupas pintosas, assim como da própria escola como um lugar para viver a viadagem. São discursos como esses - e não apenas esses - que inserem uma certa erótica do currículo (hooks, 2010; BRITZMAN, 1996, 1998, 2010) e fluem por velocidades que alteram o sentido espaço-temporal da escola.

Nestas velocidades novos agenciamentos são mobilizados, daí que tomar o currículo como algo dado já não responde às questões que emergem das agendas de politização da interseção entre gêneros, raças, sexualidades e educação. Ainda que estes campos recorram a uma tentativa de legitimar suas experiências no campo curricular através de algum compartilhamento dos sentidos de inteligibilidade do que se trata e de quem se enquadra em seus acordos. $E$ é nos termos destes mesmos acordos que há uma tentativa de fixar o que seja currículo e o seu modo de produzir raças, gêneros e sexualidades em suas categorias de reconhecimento.

É neste sentido que se deve estranhar o currículo e suas tramas discursivas presas no caráter representativo, estranhar o currículo é um convite a "curricularizar cada vez mais perigosamente, e a fornecer outros pensamentos, sonhos, emoções e humanidades diferentes" (CORAZZA,
8. Diane Arbus (14 de março de 1923 - 26 de julho de 1971), fotógrafa e escritora estadunidense conhecida através das suas fotografias de estilo freak, de pessoas comuns em seus cotidianos.

9. A engenharia curricular diz respeito ao planejamento, organização e implementação no campo das políticas curriculares. 
2009 , p. 16), aprofundando uma conversa complicada, fazendo uso da expressão de Pinar (2004), ou seja, visualizar o acesso à educação em uma conversa cultural, onde há o envolvimento de diferentes linguagens e, mais precisamente, no currículo, o espaço aberto de convergência de diferentes vozes, tradições, interesses, gêneros, etc.

Assim, currículo é concebido aqui "como espaço-tempo de fronteira e, portanto, como híbridos culturais, ou seja, como práticas ambivalentes que incluem o mesmo e o outro num jogo em que nem a vitória nem a derrota jamais serão completas" (MACEDO, 2006a, p. 289). E, preocupa-me compreender a ação das alunas nos deslocamentos das fronteiras erigidas pelos discursos curriculares sobre as formas de viver os gêneros, as sexualidades e as raças. A compreensão do espaço-tempo de fronteira se dá "no momento de trânsito em que espaço e tempo se cruzam para produzir figuras complexas de diferença e identidade, passado e presente, interior e exterior, inclusão e exclusão" (BHABHA, 1998, p. 19).

Embora haja quem defenda um projeto de currículo como o reflexo da sociedade, concebendo a sociedade como uma forma alienígena, uma metanarrativa cujo plano seja a normalização dos corpos nos regimes de coerência entre corpo, desejo e gênero e/ou raça, nação e modernidade (MISKOLCl, 2012), assim como o currículo como uma forma essencialmente normalizadora e disciplinar, penso ser necessária uma investigação do tom paternalista dessa tese. Said (2012) e Spivak (2010) apontam, ainda, como estes lugares fantasmagóricos se instauram a partir de um realismo 
protecionista que se inscreve de forma semelhante à violência que pretendem criticar.

Por isso, entendo o currículo como "um espaço que corporifica relações sociais, formas de conhecimento, de saber-poder e como território de composições e experimentações; território em que jogamos parte significativa dos jogos de nossas vidas" (PARAíso, 2006, p. 1), que, portanto, estabelece inesgotáveis maneiras de ver e enunciar para além da pura crítica ao discurso heteronormativo, sexista e racista. Em outras palavras, realizar o exercício de se escavar ou praticar uma genealogia do presente (FOUCAULT, 1989) que esteja para além da denúncia da mesmidade da norma.

Por outro lado, distanciar o pensamento curricular das metanarrativas da Modernidade e repensá-lo em perspectivas pós-estruturalistas poderia implicar uma reificação da relação servil e determinista anteriormente constituída, caso a posição tomada implicasse uma tentativa de revolução curricular a partir da sobredeterminação das metanarrativas da Modernidade. Assim, retornaríamos a uma engenharia curricular manifesta na maquinaria escolar (VARELA; ALVAREZ-URIA, 1992) que assume o exercício de esgotar a diferença (PARAÍSO, 2010a; POPKEWITZ, 2001). Desse modo, o desafio consiste em inventar potências para ensaiar possibilidades outras de uma vida vivível.

Por vezes ouvi que os estudos pós-críticos em educação estavam aparentemente distantes de uma prática descrita como pertencente ao chão escolar. Rosanne Dias e Alice Casimiro Lopes (2009, p. 87) apontam a hipótese de que esta expectativa de que pela prática se tem "a real dimensão 
dos problemas que atingem a educação brasileira" apresenta "certo enfoque empirista por valorizar como base do conhecimento 'verdadeiro' o que é apreendido, exclusivamente, pela experiência". Não é minha tarefa apontar qual perspectiva está mais ou menos próxima daquilo que se coloca como "realidade", e tal tarefa seria uma pretensão arrogante. O que faço é apontar que o caminho que optei por teorizar a discussão situa-se no âmbito dos debates pós-críticos em educação.

Entretanto, ao trazer corpos denominados queer para o pensamento deste texto, preocupa-me certa institucionalização das corporeidades (PRECIADO, 2007; PELÚCIO, 2012, 2014), visto que o modo como os estudos queer aportam no Brasil imprime tons de colonialidade, haja vista sua impossibilidade semântica quanto ao efeito provocado pelo termo, podendo ser traduzido em algo como a palavra bicha, para nós.

Contudo, valendo-me do arsenal teórico dos Estudos Queer em sua relação com as pesquisas pós-críticas em educação, tal como teorizado por Oliveira (2016). Britzman (1996) e Louro (1997, 2004), há fugas que apontam para as epistemologias de fronteira que operam em diferentes campos dos saberes e possibilitam, dessa maneira, uma multiplicidade metodológica. No mais, as incursões possibilitadas pelos Estudos Queer promovem pensamentos indisciplinados de muitas andanças e descentramentos.

A partir destas breves considerações, cabe analisar com e a partir de corpos racializados e dissidentes sexuais o currículo escolar, assim como pensar os Estudos Queer e pós-críticos em educação com os corpos e a partir do meu corpo bicha e preto na inflexão da política curricular no Brasil e no 
modo como os estudos em gêneros e sexualidades conduzem tal narrativa.

Para pensarmos tais questões, é imprescindível traçar um debate acerca da "política da diferença" (MACEDO, 2006a) para oxigenar teoricamente o pensamento curricular, visto que a base crítica que efetua uma denúncia está saturada de demonstrações de como a escola é um ambiente predominantemente opressivo e que constrói mal as sexualidades, raças e gêneros das estudantes. O contraste desta base crítica surge no momento mesmo de sua denúncia, como se aquele que a efetuasse estivesse iluminando as questões e que a partir daí poder-se-ia construí-las "corretamente".

Nesse sentido, tais críticas se encontram mais com a noção de diversidade cultural do que propriamente com a diferença. Ao atuar a partir da diversidade, termos como "inclusão, respeito e tolerância" são matizados politicamente ao currículo, como, por exemplo, a agenda anti-homofobia na Educação e as Leis n. 10.639/2003 e 11.645/2008, as quais estabelecem as diretrizes e bases da educação nacional, para incluir, no currículo oficial da rede de ensino, a obrigatoriedade da temática "História e cultura afro-brasileira e indígena". A distinção entre diferença e diversidade está inserida no campo epistemológico e, assim, diversidade cultural não é diferença cultural. A diversidade ocorre em uma oposição binária que distribui homogeneamente identidades culturais pré-dadas que permanecem intocadas no tempo-espaço. 
A diferença é da ordem da ambivalência, processo desarmônico e conflituoso que consiste em identificações híbridas. Bhabha (1998, p. 63) assim escreve:

\begin{abstract}
A diversidade cultural é um objeto epistemológico - a cultura como objeto de conhecimento empírico - enquanto a diferença cultural é o processo de enunciação da cultura como 'conhecível', legítimo, adequado à construção de sistemas de identificação cultural. Se diversidade é uma categoria da ética, estética ou etnologia comparativas, a diferença cultural é um processo de significação através do qual afirmação da cultura ou sobre a cultura diferenciam, discriminam e autorizam a produção de campos de força, referência, aplicabilidade e capacidade.
\end{abstract}

Entretanto, a cultura também é um objeto epistemológico e performativo, uma vez que ela é ficcionalizada e reificada contingencialmente como objeto do saber-poder; dessa forma, é um híbrido que passa por cotidianas intenções de fixação nas arenas de embate dos processos de significação. Mas, ainda sim, a cultura, em sua ambivalência, é também uma prática conduzida por relações de poder que classificam a diferença durante as negociações de sentido. Portanto, se tomada na perspectiva da diversidade, a cultura será categorizada, fixada no tempo e no espaço e reduzida a critérios de tolerância. Mas, se tomada na perspectiva da diferença, a cultura será enunciação e um problema indissolúvel, neste sentido, "para aqueles que insistem em repetir a tradição na significação do presente enunciativo, reivindicatório e incerto, é luta política" (PONTES, 2009, p. 36).

Levada ao currículo, a noção de diversidade trata a cultura como objeto a ser ensinado (MACEDO, 2012), subsumindo sua força à simples forma e fórmula matematizada, 
sem levar em conta que, no presente enunciativo, as práticas de significação são conflituosas em meio à diferença cultural que ocorre no cotidiano escolar. Da mesma forma, o próprio currículo torna-se objeto de representação, como algo que possui delineamentos bastante visíveis, findados em si e, por isso, capazes de formar imagens representáveis e identidades estanques. Em outras palavras, o currículo torna-se um objeto tratado como passível de conhecimento de sua essência e, assim, é constituído como ou isso ou aquilo (GAUTHIER, 2002).

O que temos observado nas atuais considerações sobre minorias sociais é que, a partir da concepção de identidade e representação, há um movimento no sentido de incluí-las (ou não) por padrões assimilacionistas em discursos que reforçam uma identidade homogênea, legitimada por autoridades e toleradas em suas políticas de reconhecimento (MACEDO, 2006a). Assim, o "incluído" é visto, na perspectiva da diversidade, como o Outro a ser tolerado, "como questão e não como ser questionador e questionado, como ser próximo, compreensível, como diferente do Eu, mas tolerável" (PONTES, 2009, p. 37).

O desafio aqui consiste em conceber o currículo como multiplicidade de agenciamentos, de modo que, não tomado como objeto delimitado por uma identidade, fosse apenas devir-currículo, uma espécie de experimentação de movimento, de vir a ser alguma coisa que sempre será outra, para que, assim, construtos como gêneros, sexualidades e raças não mais estivessem definidos como isso ou aquilo e, portanto, dentro dos limites da inteligibilidade. No limite, trata-se de voltar à questão spinoziana do "que pode um corpo?" para nos questionar, 
em uma cartografia, em termos de latitude o que pode um currículo? Uma aula? Uma escola? Em suas potências e graus de afecção; e, em termos de longitude, quais linhas compõem um currículo? Uma sala? Uma escola? Em seus espaços desconexos, territórios e desenhos (GAUTHIER, 2002).

\footnotetext{
Vemos, assim, agora, uma outra maneira de esboçar uma concepção bem diferente de currículo. Ao currículo como corpo, nós opomos uma concepção do currículo como superfície; ao currículo como ser, nós opomos uma concepção do currículo como devir; ao currículo como objeto claro e distinto, nós opomos uma concepção do currículo como "obra aberta", isto é, como obra fundamentalmente ambígua sem, contudo, cair no indiferenciado; a um plano teleológico, nós opomos um plano geométrico (GAUTHIER, 2002, p. 146).
}

Dessa forma, reduziríamos os danos de pensar as sexualidades dissidentes e pessoas racializadas como o Outro a ser incluído por uma hospitalidade hostil na categoria universal da diversidade cultural. Assim como seu grande guarda-chuvas de tolerância e respeito que precisam se reconhecer e serem reconhecidas nas imagens pré-dadas para adentrarem ao paraíso da cordialidade à brasileira, de modo que não sejam vistas como o Outro vitimizado e objeto de conhecimento.

A composição a que me proponho nas próximas páginas deste escrito é explorar, no campo do pensamento pós-crítico em educação, os significados que estudantes gays/ bichas/viados/homossexuais e pretos/negros constroem para si. De perguntar: como o cruzamento das fronteiras de raças, gêneros e sexualidades realizadas por estudantes ampliam os sentidos curriculares? De propor pensar o currículo 
como agenciamento maquínico $^{10}$ (GAUTHIER, 2002) para então observar as estratégias de alunas, para traçar linhas de fuga, assim como estratégias curriculares de apaziguamento destas linhas (PÓVOAS BRITO, 2018).

Assim, anseio com este texto demonstrar como uma cartografia pós-crítica do currículo escolar possibilita visualizar a multiplicidade de linhas que são traçadas no currículo a partir da emergência das diferenças. Especialmente, a diferença em sua versão incontornável que multiplica as linhas que flexionam o currículo em uma conversa complicada e infinitamente complexa em seus agenciamentos maquínicos.

Em vista disso, retomo o questionamento de Maria Inez Carvalho (1992) para investigar o que deixamos de ver pelo nosso anseio em apontar o que falta ao currículo. Anseio este que neblina a visão para os movimentos traçados por outros corpos, fora do limite imaginativo da normatividade, para a composição de uma experiência de si no cotidiano escolar. Assim, não me interessa, como objetivo primário, o modo como o currículo normatiza/disciplina o corpo e o desejo, mas sim questionar: o que ocorreria se o currículo fosse tomado de espanto? Fosse estranhado por corpos suspeitos à norma? Se, ao invés de excluir formas "ilegítimas" de vida, ele fosse torcido a partir das fronteiras?

Afinal, já conhecemos bem as palavras de "ordenação, de organização, de sequenciação, de estruturação, de enquadramento, de divisão, de classificação" (PARAíso, 2010a, p. 12) já conhecemos bem. Sabemos, também, que o currículo prima pela instituição de fronteiras claras e demarcáveis, identidades descritivas e sentidos fixos. Mas, se inserirmos novos elementos para pensar currículo, o que po-
10. Segundo

Gauthier (2002),

um agenciamento maquínico busca, sobretudo, investigar como algo funciona em detrimento do que é esse algo. Neste sentido, um agenciamento maquínico consiste em povoar todas as espécies de maquinismo e, assim. efetuar infinitos acoplamentos que desterritorializem o pensamento figurativo da realidade. 
deria ocorrer? Se problematizássemos seus acontecimentos enquanto produção do presente? Se privilegiássemos o múltiplo, o desarmônico, as monstruosidades que assombram o pensamento em Educação ao invés do vocabulário das identificações? A este respeito, Deleuze e Parnet (2004, p. 75) escrevem:

O múltiplo já não é um adjetivo ainda subordinado ao Uno que se divide ou ao Ser que o engloba. Deveio substantivo, uma multiplicidade que não cessa de habitar a coisa. Uma multiplicidade nunca está nos seus termos, seja qual for o seu número, nem no seu conjunto ou totalidade. Uma multiplicidade está apenas no $E$, que não tem a mesma natureza que os elementos, os conjuntos e mesmo suas relações. De tal modo que ainda que possa fazer-se apenas entre dois, não é por isso que vence menos o dualismo.

É no entre-lugar, neste "e" que nos engajaremos para pensar o currículo como um artefato cultural cujo investimento mais profundo é a vida (CORAZZA, 2001; SILVA, 2007; PARAíSO, 2004a, 2004b) e que "está implicado naquilo que somos, naquilo que nos tornaremos" (SILVA, 2006. p. 27). De modo que não mais cabe questionar se os gêneros, as sexualidades e as raças estão ou não sob o domínio do currículo, o que são cada uma destas categorias, onde emerge a raça e termina a sexualidade, o que buscamos são os agenciamentos curriculares maquínicos que nos permitam experimentar no e com o currículo cada acontecimento sem, para tal, engendrá-lo em uma configuração prévia.

Daí que nos importam as possibilidades de uma "construção positiva e criativa de modos de vida diferentes" (HALPERIN, 2000, p. 62). Assim, a citação de Macedo (2006b) que tomei de empréstimo anteriormente, a qual entendia o currículo como enunciação da diferença e espaço-tempo de 
fronteira, vem à tona para problematizarmos as normas de gênero, assim como o discurso racial e a heteronormatividade como discursos submetidos a deslocamentos que interrompem qualquer pureza originária agenciada pelos currículos.

Esta criação textual passou por alguns procedimentos de repensar o pensado. Um dos gatilhos para repensá-lo adveio do componente currículo, cultura, diferença, ministrado pela professora Eliana Póvoas, no âmbito do PPGER/ UFSB, onde, na ocasião, as discussões sobre currículo e diferença ganharam outras intensidades, o que me permitiu (des)organizar o corpo em busca de um Corpo sem Órgãos ${ }^{11}$ para a discussão, para então "caminhar com a cabeça, cantar com o sínus, ver com a pele, respirar com o ventre, Coisa simples, Entidade, Corpo pleno, Viagem imóvel, Anorexia, Visão cutânea, Yoga, Krishna, Love, Experimentação" (DELEUZE; GUATTARI, v. 3, 2012, p. 13).

Dessa forma, a experiência do componente reverberou nas formas de inscrição e de escrita, fazendo certa conexão entre o pesquisar em educação sem uma metodologia prévia e a crítica pós-estruturalista ao currículo e suas fronteiras. Não obstante, o fato de não haver uma metodologia prévia é uma opção que não retira o rigor do estudo, apenas assume que a diferença emerge do inesperado, e não nos locais estabelecidos, nos grandes organismos. Pelo contrário, a diferença é desarmônica e anárquica, por isso, cada vez mais, a fronteira entre dentro e fora da escola foi deslocada pelos fluxos do campo.

São justamente esses deslocamentos que nos servirão para pensar os modos de discutir currículo. Não são raros os momentos em que me peguei acompanhando estudantes
11. O Corpo sem Órgãos (ou CsO) é um termo cunhado por Antonin Artaud e roubado como conceito-experimento por Gilles Deleuze e Félix Guattari. O CsO funciona como um conjunto de práticas que fazem parte do nomadismo por isso, não se pode compreendê-lo, mas apenas vivê-lo/ praticá-lo. Daí que me aproprio do conceito para ensaiar uma experimentação, ao invés da interpretação dos acontecimentos. 
fora da escola, seja através de um convite para uma festa ou uma manifestação, seja simplesmente para assisti-las em performances, espetáculos, projetos sociais, etc. Também, em muitos momentos na escola, fui inquirido, direta e agudamente, sobre o que eu estava fazendo ali, do que se tratava meu estudo. Esse convite para falar sobre ele é uma experiência importante, visto que ocorre em um jogo de forças desterritorializantes, que implica uma forma de criar e recriar o que se investiga, no limite, "implica um modo de vida, uma maneira de viver" (DELEUZE, 2002, p. 127).

Antiprincípios metodológicos: manual de antiajuda para pesquisadoras à deriva

Penso e repenso sobre como fazer este estudo? Como falar sobre o meu projeto? Ora ou outra percebo certa hostilidade no olhar de algumas pessoas, como se aquilo a que eu estivesse me propondo discutir fosse uma aberração, no entanto, quando chego em casa para tentar organizar minhas ideias, sinto que se aquilo que estou pesquisando soa como uma aberração a alguém é porque o meu corpo também habita zonas da abjeção. Não pesquiso nada além daquilo que já me atravessa há anos, daquilo que me constitui em fibras e nervos. Não posso ter medo ou receio de falar sobre a pesquisa, de dizer que alguns corpos preferem se denominar "bichas" à categoria tão asséptica como "homossexual". No mais, tudo parece ser tão escorregadio na escola que me faz pensar em diferentes formas de pesquisar: cartografia, etnografia, pesquisa-ação, etc., mas queria apenas seguir sem rota, sem delimitar o tema dizendo "só me interessa aquele menino gay e negro ali", isso ainda me parece violento. Na verdade, é (Diário de Campo). 
Ao expor sobre o que se propunha este estudo para algumas coordenações, percebi, em mim, limites de uma linguagem para me expressar sobre os gêneros e as sexualidades na Educação. Este é um fato importante do início da trajetória de investigação, pois coincidiu com o momento político em que estava em pauta na Câmara Municipal de Porto Seguro um Projeto de Lei apelidado como Lei da Mordaça, que tinha como seu artigo $1^{\circ}$ :

fica vedado, na rede pública e privada do município, o en-
sino de ideologia de gênero para crianças e adolescentes
da rede pública e privada de ensino no município de Porto
Seguro, bem como a exposição pública de caráter didáti-
co/pedagógico ou distribuição de material que contenha
conteúdo impróprio (PORTO SEGURO, 2018 apud ROSE
MARIE, 2018, n.p.).

Embora a Lei tenha sido aprovada por vinte e um votos, ela não foi implementada devido ao seu caráter inconstitucional. Porém, há um reflexo deste discurso nos modos como se lida com as categorias de gêneros e sexualidades no pensamento curricular, no meu caso, às vezes, tateandoe tangenciando o tema para falar dele, sem provocar qualquer desconforto no outro, isto é, falar de uma maneira higienizada. Dessa forma, inicialmente tive receio em falar palavras como "bicha preta" e "viado" - palavras que preenchem o meu cotidiano - e não ter acesso aos espaços escolares.

A respeito da impossibilidade de flexionar uma linguagem própria para caracterizar a discussão, relembro uma passagem do conto Pai contra mãe, de Machado de Assis, citado por Leda Martins (2007, p. 55-56): 
A Escravidão levou consigo ofícios e aparelhos, como terá sucedido a outras instituições sociais. Não cito alguns aparelhos senão por se ligarem a certo ofício. Um deles era o ferro ao pescoço, outro o ferro ao pé; havia também a máscara de Flandres. A máscara fazia perder o vício da embriagues aos escravos, por Ihes tapar a boca. Tinha só três buracos, dous para ver, um para respirar, e era fechada atrás da cabeça por um cadeado. [...] Era grotesca tal máscara, mas a ordem social e humana nem sempre se alcança sem o grotesco, e alguma vez o cruel. Os funileiros as tinham penduradas, à venda, na porta das lojas [...] O ferro ao pescoço era aplicado aos escravos fujões. Imaginai uma coleira grossa, com a haste grossa também, à direita ou à esquerda, até ao alto da cabeça e fechada atrás com chave.

A máscara de Flandres é reificada aqui como a tecnologia que nos aplica o silêncio como admoestação a um possível incômodo provocado pela fala, um modo, um tanto sofisticado, de nos imputar o silêncio como metonímia para "domar nossa língua selvagem" (ANZALDÚA, 2009, p. 305, grifos meus). Nesse sentido, investigar tornou-se, sobretudo, um ato de convocação a uma constante luta para experimentar as forças que desterritorializavam a minha própria sexualidade racializada, uma resposta àquelas que requerem um organismo assimilável dentro das gramáticas de reconhecimento do que pode ou não pode ser entendido ao campo das sexualidades e racialidades no currículo, pois, de acordo com Anzaldúa (2009, p. 306), “línguas selvagens não podem ser domadas, elas podem apenas ser decepadas".

Por isso, predizer um caminho metodológico para o que se pretende discutir poderia ser tão arriscado quanto concordar com aquilo que já estava posto como sendo currí- 
culo, gêneros, raças e sexualidades. Daí que o que faço aqui é um antiprincípio metodológico, pois "a vontade de aportar com segurança faz corrermos o risco de restrição do potencial da viagem" (OLIVEIRA; PARAíSO, 2012, p. 161). Para descrever os procedimentos que adotei neste texto, recorri, por óbvio, a uma bibliografia referente à metodologia de pesquisa, entretanto, não optei por rotas seguras e demarcáveis, não optei por antecipar a viagem e, por algum tempo, pensei somente em seguir as pistas que surgiam em campo, sem saber a quais lugares me levariam.

Antes de tudo, este é um antiprincípio que está sempre ao meio, que se vale das ficções cotidianas, inventices e artistagens do imaginário poético-político de estudantes do Ensino Médio Integral de uma Escola Pública situada no centro de Porto Seguro-BA. É importante situar-me honestamente com relação à escola, por isso, antes de tudo, apresentei as intenções deste estudo à coordenação escolar com o objetivo de conseguir autorização para a observação do território.

Foram seis meses de investigação, sendo que, nos dois primeiros, me dediquei às observações e anotações em diário de campo, além de conversas informais com funcionárias e discentes. Após dois meses fui convidado pela coordenação para realizar uma oficina em um projeto da própria escola, chamado Estações dos Saberes. As Estações consistem em diversas oficinas que acontecem uma ou duas vezes por semana e obedecem a um eixo temático; no caso deste texto, o eixo em que ocorreu foi $O$ cuidado com o outro. 
Assim, nos dois primeiros meses, realizei uma imersão intensa no cotidiano escolar, isto é, quatro vezes por semana, intercalando entre turnos matutino e vespertino. Em seguida, realizei uma série de oficinas denominadas Artes, gêneros e raças: das coisas que nos são (im)possíveis. As oficinas aconteceram todas as terças-feiras durante um período de quatro meses e foram divididas em dez temáticas, a saber: 1) apresentação da oficina em sala; 2) as artes e as dissidências sexuais; 3) fotografia do sensivel; 4) a escola e o contato coma/o outra/o; 5) Poéticas diaspóricas; 6) nas entrelinhas da contemporaneidade; 7) o que pode um corpo?; 8) sobre aquilo que nunca foi dito; 9) do portão da escola para fora; 10) encontro de encerramento com a produção do artefato final.

Paralelamente ao período das oficinas, também frequentei a escola em dois outros dias da semana a fim de encontros que produzissem movimentos outros ao estudo. Contudo, não me encerrei à escola. Por muitas vezes, acompanhei estudantes em percursos outros, tais como festas, manifestações e ensaios; assim, mais que investigar, pude estabelecer uma relação de proximidade o suficiente, de modo que muitas coisas, para além do território escolar, me atravessassem. Assumo de início o currículo como um artefato penetrável por forças além das escolares.

As estudantes apelidaram a escola de Colégio Leonilson ${ }^{12}$, após termos uma oficina sobre as artes e as dissidências sexuais. Na ocasião, apresentei artistas e suas trajetórias, assim como suas obras. As personagens apresentadas ali surgiram do intempestivo movimento do território educacional, elas se produziram no ato enunciativo, algumas de- 
nominavam-se bichas, outras gays, umas identificavam-se como negras ou pretas, outras como marrom, morena, etc.

Se utilizo a palavra método é, pois, por ela designar algo não relacionado a saber o que se é cada coisa, gerar um saber sobre cada coisa, mas como um modo de pensar, de estabelecer dobras que se configurariam como potências do pensamento (OLIVEIRA; PARAíSO, 2012). Essa potência não está atrelada a uma imagem anterior, ela se produz na emergência dos encontros. Em vista disso, bicha e negritude não são objetos/sujeitos de pesquisa, mas apenas devires, passagens que não são uma verdade, uma identidade, são incoerências e anarquias, nem boas e nem más cópias, mas simulacros que fogem à representação (ZAMBONNI, 2016).

Sendo assim, como programar uma direção em busca de tais devires? Respondo categoricamente a esta questão: não há, ao menos no que diz respeito a este escrito. Talvez esta resposta dificulte ou torne escorregadia qualquer possibilidade de apreensão; e caso isso aconteça, ficarei alegre. Alegre, pois, desde a emergência contingencial do seu aparecimento, as negritudes e as dissidências sexuais são incessantemente confrontadas em tramas discursivas que compõem dispositivos que objetivam fixá-las e encerrar suas possibilidades de experimentação. Portanto, o que resta são procedimentos, apenas eles, na tentativa de me colocar em campo, analisar a produção de linhas e realizar a tarefa de tornar o currículo instituinte que, conforme argumenta a professora Elizabeth Macedo (2017, p. 30):

Envolve desconstruir discursos que visam a controlar a proliferação de sentidos, dentre os quais podemos destacar as identida-
12. Leonilson

(1957-1993) foi um pintor, desenhista, poeta e escultor brasileiro. A escolha do nome do colégio se deu após a apresentação da obra de diversos artistas LGBT. A obra apresentada sobre Leonilson foi o longametragem Leonilson sob o peso dos meus amores (2018), dirigido por Carlos Nader. Disponível em: https://www. itaucultural.org.br/ leonilson-sob-o-pesodos-meus-amoresdocumentario 
13. "O mundo da ontologia tradicional é o mundo da extensão, do espaço, de partes exteriores entre si. Um mundo completamente estático" (TADEU; CORAZZA; ZORDAN, 2004, p. 60). des estereotipadas e fixadas e a própria teoria curricular que as apresenta como horizonte. Trata-se, portanto, de um movimento no sentido da desconstrução da hegemonia, mas com o objetivo de impedir que se fortaleçam de tal maneira que se torne impossível questioná-las.

Assim, embora tenha situado a escola como o território de estudo, podemos enxergá-la como um dos itinerários, onde encontros, negociações e viagens acontecem, de modo que tais trânsitos nos importem mais que os elementos, isto é, a escola, o negro, a bicha/gay. Por isso, o verdadeiro e o falso não fazem sentido aqui, visto que só fariam sentido se pensados a partir de uma ontologia da representação ${ }^{13}$ (TADEU; CORAZZA; ZORDAN, 2004). O critério aqui é outro, é o do "Interessante, do notável ou do Importante" (DELEUZE; GUATTARI, v. 3, 2012, p. 108). Estes critérios trazem consigo não as coisas/objetos/ sujeitos/seres, mas os elementos que as constituem, ou seja, "forças, vetores, intensidades, diferenças de potencial, diferenças de energia" (TADEU; CORAZZA; ZORDAN, 2004, p. 62).

Admitir os itinerários situa-nos em uma contingência radical para o currículo, pois enunciamos desde as fronteiras das diferenças raciais e sexuais, o que nos coloca dentro e fora da escola ao mesmo tempo e, neste mesmo e, experimentamos o torrencial de vida que é o currículo. Para tanto, precisamos saber que o trem que nos governa nesta viagem, que traça itinerários, por vezes é pássaro, por tantas outras é peixe. Figura simbiótica que faz e desfaz sua forma, que ora passa e ora não, mas que ao tentar persegui-lo, capturá-lo, tornamo-nos alegres nômades a cartografar os mundos no interior do mundo escolar. 
Assim, falamos de sensações em detrimento de percepções, o que revela o território escolar e o pensamento curricular como matéria-força "engendrada no encontro entre o corpo e as forças do mundo que o afetam" (ROLNIK, 2003, p. 79), mas também, no desfazer do mundo, desterritorializar para, em seguida, reterritorializar. Falamos em criações e imaginação poético-política em detrimento dos grandes apontamentos descritivos, pois nossa preocupação não está voltada às queixas, aos quadros proféticos em educação, nem mesmo às ideologias e revoluções, pretendemos apenas contorcer, ampliar, implodir, distender o currículo.

Em 2018, as artistas Vinícius Santos e Caz Apro realizaram a performance Um Dois ${ }^{14}$. Uma das possibilidades abertas pelos corpos em cena ensaiava uma arqueologia de escavar camadas e lidar com encontros e distâncias de seus corpos em face de um jogo de luzes e sombras, relações de poder que produziam encarceramentos e linhas de fuga, formas e forças que se materializavam em desejos e gozo. A cartografia que aqui se ensaia se irriga de tais gestos artísticos para a criação. Tal como os corpos em Um Dois, podemos confrontar o currículo com a produção de virtualidades para que as roupas, as cores, os afetos e os (des)encontros na escola não se tornem camisas de força, realidades inquestionáveis de ver e enunciar sobre os corpos e o currículo.

Acionar a produção de virtualidades no currículo tem a ver com trazer à tona os acontecimentos que singularizam a vida e traçam um plano de imanência nos microcosmos das segmentações escolares (DELEUZE, 2002). Aqui temos uma outra formação de antiprincípio metodológico: aos corpos em devir-minoritário, devir-bicha e devir-negro não importam justificativas para suas ações, não se carece de redenção, uma vez que se justificar e redimir estaria disposto em 
uma política do reconhecer-se, mas não há este reconhecimento porque não se fixa a um devir, tais devires - bicha e negro - são processos abertos dos quais derivam suas próprias fabulações.

Daí que há o virtual, não como contraposição do real, mas como um acontecimento que implica o atual e as forças e formas que constituem o atual, de modo que, em um currículo, "o atual e o virtual coexistem e entram num estreito circuito que nos reconduz constantemente de um a outro" (DELEUZE; PARNET, 2004, p. 56). No virtual habita um plano que fabula a existência atual do corpo e do currículo. Por isso, um outro antiprincípio aqui é que não se comporta uma pesquisa de dados na imanência fabulativa dos devires bicha e negro, os dados cerceariam suas possibilidades de fabulações, de inventices, de linhas escorregadias. Portanto, a referência que se faz ao pesquisador no campo do pensamento curricular pós-crítico "é a analítica, a qual perpassa toda pesquisa-bicha, sem se restringir a um trecho ou outro, que possibilita a produção de dados, ou antes, de atos de dar" (ZAMBONI, 2015, p. 97).

\section{Analítica do Desejo em um currículo}

"Isso funciona em toda parte: às vezes sem parar, outras vezes descontinuamente. Isso respira, isso aquece, isso come. Isso caga, isso fode." (DELEUZE; GUATTARI, 2010, p. 11)

O que nos interessa em uma analítica do currículo é, antes de tudo, o roubo, a prática descarada de capturar o resultado dos encontros e compor a partir destes encontros. Realizar bricolagens através do inesperado e provocar ten- 
são no novo para que ele nos violente o pensamento, nos coaja a pensar cada vez mais em como fabricar uma discussão que entoe o cântico dos malditos ${ }^{15}$ : das bichas, putas, negros/as, mulheres, crianças e todas aquelas que, na busca por um nome, perdem a figura do seu rosto.

Por isso, grandes questões como aquelas que se referem à formação dos sujeitos ou o currículo com dispositivo de subjetivação não nos cabem aqui, nosso objetivo é, talvez, mais modesto, não investimos no currículo como uma máquina abstrata dirigida à significação, interpretação e subjetivação, mas à experiência. Em vista disso, pensamos em agenciamentos, pois entendemos que tudo que se desenha no espaço a ele também foge; nesse sentido, tratamos de linhas que se multiplicam e produzem a multiplicidade no currículo.

Deleuze e Guattari (2012, v. 3, p. 13) escreveram: "não basta dizer Viva o múltiplo, grito de resto difícil de emitir. É preciso fazer o múltiplo". Estas palavras nos convocam a uma guerra, pois a multiplicidade possibilita:

1 Colocar no centro da ontologia os processos de movimento e de devir, em vez das noções estáticas de essência e de 'ser' já-é- para-sempre constituí- do; 2 permitir pensar a diversidade e a variedade do mundo sem recorrer às noções tradicionais de uno e múltiplo. Em suma: não acontece muita coisa de interessante ou de novo num mundo feito de essências; não dá pra fazer muita coisa interessante ou nova num mundo feito de essências, a não ser, partindo das coisas, classifica-las de acordo com a essência que expressam ou, partindo das essências, perguntar-se como elas se individualizam nas coisas (TADEU; CORAZZA; ZORDAN, 2004, p. 107).
15. Ver mais em: CORAZZA, Sandra Mara. Para uma filosofia do inferno na Educação: Nietzsche, Deleuze e outros malditos afins. Belo Horizonte: Autêntica, 2002. 
Ao colocar o movimento no centro da ontologia (e da investigação), abdicamos de qualquer noção essencial do/s objeto/s, assim, em critérios de forma, a multiplicidade permite-nos perguntar em qual escola realizamos o estudo? Quais e quantos são os sujeitos que interpelamos? Mas, ao mesmo tempo, em critérios de força, podemos perguntar quais linhas de força trespassam o currículo da escola analisada? E quais, quando somadas aos devires bicha e negro, compõem linhas de fuga?

No percurso pelo Colégio Leonilson, entramos em um jogo de forças e formas que ora subtraía ora multiplicava. Ao subtrair, retiramos, de um conjunto de dados, uma unidade que o totaliza, isto é, uma territorialização do campo curricular. Territorializar é enclausurar forças que põem em devir a vida (DELEUZE; GUATTARI, v. 4, 2012), é delimitar o que é dentro e fora da escola, por exemplo, assim como marcar uma relação de propriedade com certas categorias como gêneros, raças, sexualidades, religião, etc. No entanto, acontece que tão logo eram alçados a delimitações, estes territórios fugiam, isto é, eles se desterritorializavam. A desterritorialização "é o movimento pelo qual se deixa o território" (DELEUZE; GUATTARI, v. 4, 2012, p. 186).

Assim, tivemos a tarefa de tensionar a pesquisa a ponto de desterritorializar a investigação, o currículo, a escola, os desejos. De fato, não sabemos se alcançamos, mas tentamos, e isso instaura um duplo ao estudo, tentar investigar sem imagem, isto é, pensar sempre nos acontecimentos como imanentes, e ter uma ideia se "isso tá me levando a algum lugar?" (Diário de campo, 18 de setembro de 2018). Abrir mão de um caminho seguro concorre com certos riscos, como o de pensar o estatuto da pesquisa e inserir nela uma precariedade que acompanha a vida da pesquisadora. 
Certa vez, após uma oficina sobre poéticas marginais, para as Estações dos Saberes, Caíque ${ }^{16}$, um estudante do segundo ano do Ensino Médio, me disse que tinha o costume de escrever poesias, mas que ainda não tinha coragem de mostrá-las. Eu o incentivei a ler alguns, mas percebi que minha insistência estava causando desconforto a ele, por isso parei. Após alguns dias ele me encontrou e perguntou sobre o que eu estava escrevendo, pois um de seus colegas tinha dito que eu o havia entrevistado. Expliquei a ele do que se tratava, sobre como não era apenas "um estudo", mas modos de construirmos juntas outros espaços de existência. Caíque então me disse que queria que eu lesse seus poemas.

Muitos dos escritos de Cá́que estavam carregados de uma linguagem erótica, de uma produção de desejos e medos, de dúvidas e esperanças. Possuído de um estilo notívago de escrita, muitos versos remetiam seu corpo à noite, como se o espaço que possibilitasse sua existência, ao mesmo tempo, "tivesse que esconder quem sou"17. Ele me disse que não lia seus poemas, não por vergonha ou timidez, mas porque era muito pessoal. Os poemas de Caíque, assim como nossas conversas, me causaram um extremo desassossego, implicou a mim um ato de violência que me coagia a pensar em uma erótica da cartografia que ousasse para além dos limites de inteligibilidade dos gêneros e das sexualidades no currículo.

A escrita de Caíque agenciava forças que não cabe a mim significá-las ou interpretá-las, era uma escrita que se multiplicava em tantas outras e que, ao me atravessar, se singularizava e mudava sua intensidade, que, de algum modo, me fazia questionar: "como fazer uma pesquisa que relacione o currículo com a erótica dos corpos? Como escrever um 'de- 
18. De acordo com Corazza (2013, p. 22), a imagem dogmática do pensamento integra o pensamento deleuziano como uma crítica à filosofia da representação, a qual opera de modo "monocentrista, positiva as cópiasícones como sucedâneos válidos do Original, enquanto teme os simulacros". sejo sem gozo'?" (Diário de Campo). Estas perguntas surgem, pois, para incitar um pensamento sobre um modo de escrita que acompanhe o movimento contínuo das paisagens. A escrita de um estudante carregada de desejo se dá pela maquinaria de inventar sua realidade, de fazer da matéria uma forma plástica moldada pela força do seu desejo.

"Quase nada do que escrevo é verdade, eu só imagino como seria, assisto em um filme, uma novela, ouço uma conversa", contou Caíque. Assim, a escrita era uma produção do desejo, "desejo que é máquina viva" (BENEDITTI, 2009, p. 72) e que possibilita a criação de outros territórios para se existir, que surge da emergência dos encontros; e não havendo encontros, inventam-se, improvisam-se, maquinam-se conexões para traçar fugas às formas, escoar pelas sendas do insuspeito.

A produção do desejo cartografado por este texto se dá no campo da política, pois retira a escrita da ordem, inaugura o novo e reconhece que "a língua, no seu curso natural, é palavra-de-ordem que precisa ser torcida. É porque a língua é palavra-de-ordem que é preciso fazer gaguejá-la" (TADEU; CORAZZA; ZORDAN, 2004, p. 102). O desejo a que se investe a cartografia dilui a ordem para produzir multiplicidades a partir de uma escrita da multiplicidade. Olhar para os movimentos dos corpos que produzem as diferenças sexuais e raciais e não os encerrar por meio de processos taxonômicos saturados de imagens dogmáticas do pensamento ${ }^{18}$. 




\section{"Todas nós nascemos nus e o resto é drag": devir-bicha em um currículo}

Era uma vez uma figura demasiadamente destemida que transitava por entre potes de ouro e carrinhos de mão ${ }^{19}$. Seu corpo era assim, altivo e variável, notívago e mutável, ora habitava a figura humana, n'outra se rasgava e revelava o animal que residia por sob a humanidade. Falava com espíritos, encruzilhava-se em ancestralidades para arquitetar máquinas de guerra ${ }^{20}$, trazia Nietzsche e toda uma multidão de pessoas na mesma sentença, não distinguia escolas do pensamento francês e alemão do pensamento das multidões. Filosofava com cantoras pop, assim como debochava daquelas que pensavam saber sobre ela.

A bicha é por excelência uma transformação incorpórea ${ }^{21}$. Quando convocada - se convocada -, fratura os sentidos das humanidades dispostas em campo para um fértil
19. Refiro-me ao caso da Travesti Dandara. Ver em: http:// g1.globo.com/ceara/ noticia/2017/03/ apos-agressaodandara-foi-mortacom-tiro-dizsecretario-andrecosta.html 
20. Máquinas de Guerra é um conceito proposto por Gilles

Deleuze e Félix Guattari (v. 3, 2012. p. 97), em que "um

fluxo de guerra absoluta que escoa de um polo ofensivo a um polo defensivo não é marcado senão por quanta (forças materiais e psíquicas que são disponibilidades nominais da guerra)". Assim, esse conceito é uma potência que, atrelada a um nomadismo, se move e abala os modelos propostos pela máquina estatal.

21. A expressão bicha, como utilizada, não se refere à representação de um ser corpóreo, anteriormente definido pela própria expressão.

Neste sentido, a bicha se faz enquanto enunciação que produz uma disposição para compreensão do real, da bicha enquanto realidade. O conceito transformações incorporais foi criado por Deleuze e Guattari (v. 2, 2012) e aparece pela primeira vez no segundo volume de Mil platôs: capitalismo e esquizofrenia. reconhecimento. Muitas vezes, ela não quer se reconhecer, mas quer ser conhecida, por isso se fabrica, se acopla a outras máquinas - máquinas-estudantes, máquinas-artistas, máquinas-docentes, máquinas-currículo - para que suas moléculas se multipliquem. Para conhecê-la, é preciso antes saber que, muito mais que ao poder que territorializa sua existência, ela se define por suas linhas de fuga.

O seu território é sulcado, sua topografia possui declives, acumula entulhos nos canteiros do seu corpo sempre em obra. Nasce nua, tudo o que vem depois é drag, é pura montagem, performance e espetáculo. Quando perguntei pela primeira vez a Cazu o que era uma bicha, ele riu de mim, riu da pergunta, debochou do fato dele ter se definido como sendo uma bicha preta e me devolveu: "você deveria saber, afinal, você é uma". A pergunta o que é soa estúpida, pois estamos sempre à beira de nos tornar, insaciáveis que somos, este processo corre, devém.

Concordo com Jésio Zamboni (2016, p. 12), para quem a bicha não se presta a ser objeto ou sujeito de conhecimento, pois, antes de qualquer coisa, ela é "um fluxo que atravessa nossa contemporaneidade". Ainda segundo o autor:
A bicha interroga o que seja ser alguma coisa, desmonta o estatuto do ser no pensamento. Ela perturba os códigos e rituais que nos fazem acreditar que somos algo. Radical, a bicha questiona qualquer fundamento possível para o ser, especificamente o humano das democracias modernas. Uma figura 
problemática, uma personagem incômoda, corruptiva das imagens estáveis e confortáveis que criamos para nós mesmos. A bicha configura uma insistente problematização do que somos, rejeitando as finais soluções - que são sempre propostas pretendendo exterminar o problema, (dis)solver suas (com)posições (ZAMBONI, 2016, p. 12).

Prenhe de mutações, estando à margem da própria margem, ela, a bicha, desorganiza uma concepção linear do sujeito. Enquanto bicha e preta ela inexiste, pois não se nasce bicha, torna-se, e esse tornar-se é uma constante. Nesse caso, o ser bicha anula-se através do devir-bicha. Corpo de passagens que escapa a quaisquer políticas de representação. Não tenho intenção alguma de produzir neste texto um processo taxonômico, por entender que qualquer movimento nesse sentido é uma via do poder hegemônico que emudece, invisibiliza e impõe cercas ao devir-bicha.

Assim, seria impossível, neste escrito, uma delimitação do que é ou não é a bicha preta, pois qualquer movimento nesse sentido já seria o estrangulamento da sua voz a partir do conhecimento. De modo geral, as relações que buscam conhecer e demonstrar não são experiências, podemos até saber algo a mais, como escreve Larrosa (2011), mas seremos os mesmos que antes, onde nada nos tenha transformado. O conhecimento que interroga o que é alguma coisa congela-a a partir do verbo ser, encerrando as experiências que se afirmam nos devires. 
No Brasil, a figura da bicha é parte presente do imaginário nacional, das novelas aos desenhos, dos quadrinhos aos romances. A bicha assume a figura de um terror fantasmagórico que assombra uma pretensa noção de estabilidade não apenas da heterossexualidade, mas da própria homossexualidade. Assumida como xingamento é relembrada em seu juízo da monstruosidade como a figura do escárnio. Na escola, a bicha é vivificada pelo discurso, pela verbalização de um comportamento desorganizador da vida coletiva.

Nas muretas dos mictórios masculinos são grafadas: "fulano de tal é bicha", "ciclano é viado". Ainda que assuma uma forma subversiva e questionadora, a bicha, infelizmente, não é capaz de desmaterializar os signos que compõem a sua vida. As eiras e beiras são incansavelmente erguidas ao seu redor, delimitando um espaço, uma identidade, enfim, uma noção fixa que privatiza a vida. O seu corpo é insistentemente lançado ao jugo da colonização, que objetiva territorializá-lo.

O movimento histórico-cultural de um triplo tabu a fez negada pela religiosidade cristã (pecado), pelo Estado (crime) e pela ciência (patologia), durante o século XIX, que, com pequenas modificações, se arrastam de forma reificada até a contemporaneidade. Da rebelião de Stonewall até hoje, a bicha fez com que todas as tentativas de apreensão fossem falhas, inclusive aquelas no interior do próprio movimento gay. 
Mas, se a bicha é produto das práticas de enunciação que ocorrem no interior de uma cultura, a negritude também o é. Dessa forma, a bicha preta é inventada e reinventada discursivamente sempre que a ela se faz menção. Daí que a escola se institui como um dispositivo regulador que, em termos foucaultianos, possibilita, através de suas discursividades e evidências, a captura em formas.

Por isso, seria irrelevante para esta discussão crer em um oculto das práticas escolares, crer que há discursividades que ocultam a real intenção da escola, pois, dessa forma, partiria do princípio que existe uma verdade subliminar que não se enuncia nem se faz visível. Mas, aquilo que não se enuncia nem se faz visível inexiste, pelo menos no que diz respeito ao espaço-tempo. Dessa forma, "não há nada a descobrir no sexo ou na identidade sexual; não há segredos escondidos; não há interior. A verdade sobre o sexo não é uma revelação; é sexdesign" (PRECIADO, 2018, p. 38).

Mas, nem por isso, as tentativas de fixar a sexualidade diminuem. Afinal, no interior das redes discursivas, os jogos de poder anseiam produzir identidades fixas, assim, classificáveis e transcendentais (MACEDO, 2006a). Identidades preestabelecidas dispostas em malhas do reconhecimento, prontas para serem performadas. O currículo, em uma leitura majoritária, ou seja, molar, atua, também, neste sentido: estrangular os fluxos de um devir-bicha, liberando-a da possibilidade do caos. Lembremos das palavras de Deleuze e Guattari (1997, p. 259 apud ZAMBONI, 2013, p. 104) sobre nossos anseios pela ordem: 
Pedimos somente um pouco de ordem para nos proteger do caos. [...] E, enfim, para que haja acordo entre coisas e pensamento, é preciso que a sensação se reproduza, como a garantia ou o testemunho de seu acordo [...] com nossos órgãos do corpo, que não percebam o presente, sem lhe impor uma conformidade com o passado. É tudo isso que pedimos para formar uma opinião, como uma espécie de "guarda-sol" que nos protege do caos.

É, pois, neste jogo entre tentativas de produção e fixação de significado e performance-espetáculo que emerge o espaço-tempo limítrofe, como argumenta Macedo (2006a, p. 289), que torna "possível pensar a existência do Outro". Esse entrelugar ambivalente que instaura duplos, tornando viáveis existências que não necessariamente são oposições a uma cultura hegemônica, mas híbridos culturais.

Nesta seção, analiso as linhas vertiginosas desenhadas sobre as superfícies escolares pelas quais estudantes gays/bichas/homossexuais negros se experimentam e se fazem. Investigo como a sexualidade experimentada pelos estudantes concorre à invenção de outros modos de existência. Para tanto, apresento algumas personagens e suas narrativas performáticas (BHABHA, 1998), e parto do pressuposto teórico que sexualidades dissidentes e racializadas podem, através dos jogos de visibilidades do currículo, habitar campos heteronômicos de atualização dos modos de se instituir um saber sobre os corpos a partir do reconhecimento. 
Constituo, assim, a primeira paisagem deste texto, assim como suas cenas que se deixam penetrar por discursos aparentemente não curriculares. Talvez estejamos demasiadamente saturados das imagens comuns daquilo que costumamos chamar currículo, isto é, seleção, ensino-aprendizagem, produção, conhecimento, rendimento escolar (PARAíSO, 2010a), e, decerto, as experiências nos campos das sexualidades e racialidades, à primeira vista, parecem dizer pouco sobre o currículo.

Assistimos, nos últimos tempos, uma explosão de discursos que interferem no pensamento curricular, muitos deles enunciados por múltiplos sujeitos, como a ministra da Mulher, da Família e dos Direitos Humanos, Damares Alves, e o deputado federal Alexandre Frota. Discursos que mantêm uma linha comum no sentido de apontar como a "cultura gay" pretende criar um "manual de como se tornar gay" 22 .

Nesse sentido, o currículo e suas possíveis relações com os gêneros, as raças e as sexualidades estão em evidência para alguns em detrimento de outros, isto é, daqueles que acreditam que tais temas não atravessam a composição de um pensamento curricular. Dessa forma, convido-as a torcermos o currículo a partir de um devir-bicha e corrermos as linhas para saber até onde podemos chegar, dadas as nossas limitações espaço-temporais. 
Assim, se faz crucial atentar ao que venho chamando de devir-bicha e como ele se dá na imanência da cartografia escolar. As dissidências sexuais racializadas que aponto nesta discussão se dão no desejo de criar outros modos de existências para além daqueles ditados e reiterados pela maquinaria escolar. Por isso, são sexualidades vividas nos entrelugares da escola e que criam zonas de experimentações, de criações e invenções de vidas. Por serem fluidas, podem agenciar encontros, afetarem e serem afetadas por outros corpos e, assim, se pulverizarem em multiplicidades - que escapam à identidade.

São através dos movimentos que alunas criam linhas flexíveis para novas conformações, novos problemas para si, para a escola e para qualquer diretriz. Por se tratar de operações do desejo, as sexualidades estão em contínua produção, porque o sentido do desejo está em seu fluxo que sempre corre para a produção da diferença. Nesse sentido, a diferença é puro devir, pura produção de singularidades. Daí que, ainda que eu trate das experiências de estudantes gays e negros (ou bichas pretas), como dito anteriormente, cada estudante, em sua potência, é uma força singular que não está representada em um outro gay e negro. Em outras palavras, não se trata de forma, mas de força, embora ambas coexistam.

Ao cartografar os encontros e as experiências ocorridas no Colégio Leonilson, observei - não em um processo passivo - as linhas que são compostas, pois é através des- 
sas linhas, dos seus ritmos e das suas naturezas que cada estudante potencializa suas singularidades. Se o currículo é sinalizado como uma linha de natureza dura (PARAíSO, 2004a), muitos movimentos estudantis são flexíveis e ensaiam variações de natureza, ou podem mesmo se solidificar.

A figura da bicha ensaia linhas de fuga que radicalizam os fluxos por alcançarem movimentos desterritorializantes. Não sabemos qual o mecanismo que a dispara, mas, ao ser disparada, há possibilidades de fissurar sistemas sociais. No entanto, com isso não quero dizer que qualquer figura dissidente sexual e racializada é em si subversiva e incapturável pelas máquinas sociais, apenas indico que, muitas vezes, a emergência da bicha inaugura uma interrogação às "normalidades" de um pensamento viciado em imagens.

Na escola, não foram raras as vezes em que encontrei possibilidades de ministrar oficinas voltadas especificamente às alunas gays. Recebi convites da coordenação para dizer "como é importante se prevenir desses encontros rápidos que hoje existem nesses aplicativos" (Cássio, Coordenador Pedagógico). Também, com um grupo de colegas, fomos indicados para "conversar com os alunos sobre homofobia e racismo, para ajudar a diminuir o número de casos na escola" (Marcela, Professora de Química). Em ambos os momentos, é interessante ressaltar que não havia alunos gays em sala, o que foi motivo de insatisfação para alguns: "tá vendo, a gente faz as coisas, mas os que devem participar mesmo, não ficam, vão tudo embora" (Marcela). 
Algumas linhas cartografadas se dão no sentido que a bicha não se conforma a ser objeto de conhecimento, pelo contrário, é um fluxo que o questiona, que debocha:

No primeiro ano, a professora de artes pediu pra todo mundo da sala fazer um desenho... aí eu sempre gostei de provocar (risos). Fui lá e desenhei Pedro Álvares Cabral com a mão na cintura e de tomara-que-caia (risos), eu tinha visto no facebook, todo mundo adorou (Túlio, aluno do $3^{\circ}$ ano do Ensino Médio)

É essa não conformação com o estatuto do ser já dado que é paulatinamente desmontada por atos de dar, dar sempre um outro sentido a si a partir das criações que estão sempre à deriva de mutações, por isso, antes de tudo, entendo o fluxo das sexualidades como um devir. Nesse sentido, não denomino estudante algum como bicha, pois a bicha não é, ela apenas devém como pontos de passagem, como escreve Guattari (1987, p. 36, grifos meus):

A oposição homem/mulher serve para fundar a ordem social, antes das oposições de classe, de casta, etc. Inversamente, tudo o que quebra as normas, tudo o que rompe com a ordem estabelecida, tem algo a ver com a homossexualidade ou com um devir animal, um devir mulher, etc.

Daí que, embora as políticas representacionais aumentem incessantemente, a exemplo do número de oficinas, minicursos e rodas de conversas, estudantes gays, muitas vezes, não se prestam a uma propriedade delimitada ou categoria definida. Essa linha dura desenhada pelo 
currículo é tensionada em seu discurso acerca das populações LGBTs, pelos gritos impessoais de um devir-bicha, "de uma vida impessoal, contudo singular, que libera um puro acontecimento sem acidentes da vida interior e exterior, isto é, da subjetividade e da objetividade disso que sucede" (DELEUZE, 2004, p. 162).

\section{Cena I - Pode um currículo festejar?}

Uma mãe entra na escola enfurecida, caminha por toda a guarita e vai em direção à sala da coordenação escolar. Ao entrar na sala, ela começa a questionar o motivo de ter tanta festa na escola. Eu matriculei meu filho aqui foi pra ele aprender, não para ter que ficar comprando isso ou aquilo para a festa tal [...] eu acho um absurdo isso: perder o tempo da aula fazendo festa (Diário de Campo, 16 de outubro de 2018). Ela tecia longas falas a respeito de como o número de eventos da escola desviava sua função principal, isto é, ensinar nossos filhos a ser gente. Isso é coisa desses professores preguiçosos que não querem trabalhar, não querem dar aulas.

Eu já estava acompanhando um grupo de três estudantes que esperavam o momento do evento para apresentar a performance que eles estavam ensaiando há algum tempo. Cristiano ${ }^{23}$ e $\mathrm{Cazu}^{24}$ após serem apresentados ao poema Samba-Canção ${ }^{25}$, de Ana Cristina César, durante 
26. O Buraco da Gia é um ponto de alta movimentação situado no Complexo do Baianão, bairro periférico de Porto Seguro.

27. Nome fictício escolhido pela estudante. uma conversa que tivemos fora da escola, se interessaram a ponto de se mobilizarem para incorporar o texto ao que eles estavam chamando de a mulher do vestido de sangue. A mulher do vestido de sangue era uma performance que, segundo Cazu, falava das dores de ser mulher e mãe de crianças negras. Eu perdi um irmão recentemente, foi pego ali próximo ao Buraco da Gia ${ }^{26}$. Minha mãe ainda chora muito.

A performance contava com Andressa ${ }^{27}$, uma estudante do terceiro ano do Ensino Médio, no papel da mãe e seus dois filhos, Cazu e Cristiano, interpretando o papel de Caim e Abel, respectivamente. A reviravolta estava no intercurso da famosa narrativa bíblica, pois a intenção delas era a de inverter a história, isto é, Abel matar Caim por motivos religiosos, por isso que eu [Cazu] faço o papel de Caim, porque sou gay e negro, já o Cristiano é branco e aqui ele será um homem hétero (risos).

"O vestido vermelho", continuava Cazu, "era o sangue dos jovens negros assassinados, mas, também, pensando agora, pode ser o de qualquer LGBT, né?" Dessa forma, Cazu, Andressa e Cristiano ensaiaram meses a fio para a produção da performance. Elas queriam que fosse algo que chamasse a atenção de todas na escola, assim, em quase todas as semanas dos últimos dois meses que precederam à performance, eu recebi ligações e mensagens com aquilo de mais novo que elas estavam articulando. Um grupo foi montado para trocar indicações de filmes, vídeos e algumas leituras de ações violentas cometidas contra pessoas na região. 
Talvez, por isso, o fato de uma mãe ter ido à escola com as queixas sobre o evento tenha me mobilizado a questionar: como as festividades agenciadas por alguns discursos curriculares constituem importantes linhas para uma visibilidade bicha? Por um lado, uma estudante me dizia que a zoação só acontece quando a pessoa tá no armário, por outro, uma professora me contava que "para estudar sobre sexualidade na escola, é só observar as festas, quem tá sempre à frente são os estudantes gays" (Berenice, 44 anos).

Esses acontecimentos me levaram às festividades escolares como local disparador de redimensionamentos de discursos curriculares sobre gêneros, raças e sexualidades, assim como me colocaram em uma direção que apontava para o currículo a partir das suas fronteiras, visto que são poucos os trabalhos que discutem o currículo a partir das festas escolares, estando elas quase que à margem do pensamento curricular. Daí que nos cabe perguntar: pode um currículo festejar?

Dessa forma, tomo alguns eventos escolares como entrelugares que tornam possível enxergar o currículo a partir de outros locais ou, mesmo, da fronteira. A intenção não está em interpretar acontecimentos, mas em verificar, junto a eles e com eles, os agenciamentos, assim como as linhas de fuga que são produzidas nos fluxos curriculares. Ora ou outra eu escutava de professoras e familiares de alunas que "a escola tinha muita festa e que nesse ritmo dificilmente o aluno conseguiria aprender alguma coisa; 
não temos tempo o suficiente para dar todos os conteúdos (Juliana, professora de Biologia). De fato, algumas das escolas por onde passei, no decorrer do estudo, possuíam uma agenda que contava com uma ou mais festas por mês.

Muitas destas narrativas que põem em jogo as escolas como um lugar para ensinar aferem suas qualidades de acordo com índices, sejam eles governamentais ou não, mas, em todo caso, apontam sempre para uma resposta em nível concreto das práticas de ensino, isto é, aprender a calcular, escrever, ser alguém, ser gente, etc. (MACEDO, 2016). Narrativas dispostas em expectativas para o futuro que tornam a educação o resultado de um cálculo de aprendizagens e ensinamentos refletidos no saber fazer ou dizer.

No interior dessa forma pragmática de se conceber a escola, as experiências ocorridas são subsumidas a meras consequências de se estar na escola, as experiências são tidas como acontecimentos exteriores à instituição, criando-se um ideal binário e, portanto, moderno, onde em um polo estaria o currículo e, em seu polo oposto, acontecimentos festivos. Dessa forma, um evento escolar como uma festa, por exemplo, não poderia ser pensado, por essa lógica, como um momento de aprendizagem, mas apenas como um acontecimento que faz perder a aula.

De acordo com Varela e Alvarez-Uria (1992), é a própria emergência de novas formas curriculares que marca uma ruptura espaço-temporal na qual a escola é concebida 
na modernidade. Na história da maquinaria escolar, pode-se notar diferentes mobilizações festivas como agentes marcadores do Estado nacional brasileiro; assim, raças, sexualidades e gêneros também são agenciados conforme a intensa disputa das narrativas nacionais para modulação de um imaginário social comum e partilhado.

Por isso, assumo que a descrição que faço desses acontecimentos estão distantes de apontar um funcionamento exato ou uma justificativa para as festas escolares, apenas admito que se trata de eventos abertos aos corpos e seus fluxos e, assim, tanto são produzidas como produzem vidas. O que faço é, antes, investigar as linhas produzidas por estudantes nas festas como parte precária da maquinaria escolar que inscreve, a partir do currículo, os corpos em gêneros, raças e sexualidades.

Por esse motivo, percebi, como havia dito a professora Berenice, que estudantes gays faziam parte não apenas das performances artísticas, mas da produção de todo o momento escolar. Havia danças, teatro, performances, festivais de música e poesia, sendo que todos mantinham em comum a presença de estudantes gays como linha de frente da organização, da divulgação e das apresentações. Assim, o que me importava nestas festividades eram os movimentos, os fluxos e a torrente de vida que, molecularmente, atravessava e agenciava a participação de estudantes gays. 
Essa participação não se dava em um binarismo currículo/festa, como se o primeiro fosse instaurado como um real, e o segundo, como uma distração, mas, ao contrário, como elementos de diferentes intensidades que constituíam devires. Provocações virtuais advindas das estudantes que promoviam multiplicidades ao currículo. Investigar estas linhas, que se inscrevem como minoritárias e flexíveis, implicava a imagem do pensamento às volatilidades e, a qualquer paisagem, a transitórias viagens.

Estudantes, como Cazu, Andressa e Cristiano, ao se debruçarem sobre a criação de um espetáculo, afirmam a diferença como potencialidade virtual, pois “criar é produzir a diferença essencial que afirma os simulacros e faz a vontade de verdade virar vontade de potência" (TADEU; CORAZZA; ZORDAN, 2004, p. 25). Assim, os sentidos implicados nos gêneros e nas sexualidades racializados permitem um encontro com o fora, o que, no limite, é uma colisão que impele à criação, a partir de novos territórios e paisagens.

Contudo, essa colisão produtora de um híbrido é convocada desde as fronteiras dos elementos distintos que se conjugam para criação de singularidades, daí que uma cena ou uma paisagem, como apresentada aqui, se dá a partir da criação de singularidades dos elementos que nela habitam, por isso: 
a paisagem é matéria vulgar que nos induz às paixões, afectos desmedidos e incertos produzidos por fluxos dionisíacos, velocidades e ritmos que retumbam em largas margens de indefinição, sem nenhuma imagem formada. Nessa matéria rechaçada, efeito do transe embriagado, é que se insurgem os problemas do campo educacional: impulsividade animalesca, descargas escatológicas, suscetibilidade de humores, dissonância nos tempos de aprendizagem, encontro de corpos, misturas de matérias, deglutições, gritarias, risadas, aglomerações, modos desmesurados e desmantelamentos (TADEU; CORAZZA; ZORDAN, 2004, p. 28).

Assim, o envolvimento de estudantes em festas escolares concorre, também, com a criação de caminhos para uma inteligibilidade sobre os seus corpos, visto que tais eventos podem ser tomados a partir de uma ambivalência, isto é, compreender que, na disciplina ou no controle, o que está em jogo não é apenas um modo de fixar os corpos, mas o exercício ativo e permanente de colocá-los em movimento. O movimento produz desenhos de mapas que traçam afetos e relações, palavras e coisas.

Desse modo, um currículo se produz mais pelas coisas que ele movimenta do que por certa estagnação dos sentidos dessas coisas, visto que o principal investimento do poder recai sobre a produção de corpos. Assim, o currículo, através das festas escolares, faz falar e ver, também, sobre as sexualidades e gêneros racializados como mecanismo disparador de uma produção do que é ou não um corpo-bicha e um corpo-negro. 
Em Não do sexo rei - ao ser entrevistado por Henri-Lévy sobre uma "ideia de que a miséria sexual vem da repressão" (FOUCAULT, 2017, p. 349) e que para ser feliz, antes de tudo, é preciso "liberar nossas sexualidades", o que poderia resultar em uma conduta policialesca do sexo -, Foucault (2017, p. 349, grifos meus), assim o responde:

Sim. E é por isso que eles nos colocam em uma armadilha perigosa. Eles dizem mais ou menos o seguinte: "vocês têm uma sexualidade, essa sexualidade está ao mesmo tempo frustrada e muda, proibições hipócritas a reprimem. Então venham a nós, digam e mostrem tudo isso a nós, revelem seus infelizes segredos a nós..."

Esse tipo de discurso é, na verdade, um formidável instrumento de controle e de poder. Ele utiliza, como sempre, o que dizem as pessoas, o que elas sentem, o que elas esperam. Ele explora a tentação de acreditar que é suficiente, para ser feliz, ultrapassar o umbral do discurso e eliminar algumas proibições. E de fato acaba depreciando e esquadrinhando os movimentos de revolta e liberação...

Toda a organização festiva na qual alunos gays eram descritos como protagonistas colocava em movimento os seus corpos: dança, teatro, performance, decoração, etc. Essa produção curricular que faz os corpos circularem possibilita questionar: até que ponto pode um corpo gay se movimentar na escola? Uma vez que algumas linhas desenhadas por corpos de estudantes gays se lentificavam em espaços de grande movimentação cotidiana na escola, como é o caso dos recreios/intervalos, atividades esportivas e conversas no portão de entrada. 
Um outro ponto que cabe esclarecimento é que, ao me atentar às paisagens festivas da escola como um entre- lugar, assumo que tais paisagens competem mais aos corpos em trânsito do que aos povos que nelas habitam. Novamente, são os movimentos que nos interessam, por isso que não questiono se festas escolares são ou não lugares de aprendizagem, se gêneros, raças e sexualidades estão ou não em jogo no movimento dessa paisagem. Caso assim o fizesse, estaria reiterando o binarismo que compreende as festas como apartadas do sentido - tão espelhado nos valores da Modernidade - do currículo.

Compreender os agenciamentos que os currículos enredam sobre os corpos gays no momento das festas ensaia uma suspensão do pensamento curricular que engendra a escola como um espaço-tempo de ensino. Nesse sentido, tensionar o currículo a partir dos deslocamentos das margens racializadas de gêneros e sexualidades instaura um efeito migrante, sempre em deslocamento, dos corpos de jovens negros e gays e inscreve, como assinalou Homi Bhabha (1998, p. 25), que "o olho mais fiel pode agora ser aquele da visão dupla do migrante".

Elizabeth Macedo (2017, p. 18) preocupa-se como, ao longo do tempo, tem ganhado força "a ideia de que a escola é um lugar e um tempo habitado majoritariamente por crianças que cruzam os seus portões para aprender algo que produzirá efeitos, seja sobre a sociedade seja sobre elas próprias como sujeitos" 
Esta ideia que alberga currículo e conhecimento como restrito às formas, transforma a educação em práticas de ensino e, assim, escamoteia a diferença e reduz o currículo àquilo que pode ser ensinado e aprendido, em suma, aquilo que acontece na sala de aula (RIBEIRO, 2016). Assim, problematizar as festividades enquanto virtualidades (PÉREZ, 2002) possibilita a visualização rizomática dos encontros e ligações efetuados no momento mesmo do seu acontecimento.

Isto posto, podemos partir de dois pressupostos estabelecidos pela observação em campo, em que 1) alunos gays e negros são protagonistas das festas escolares; e 2) o entendimento do currículo como conteúdo a ser ensinado estabelece uma fronteira que encerra os limites do currículo à sala de aula, e as festas são tomadas como não pedagógicas, podendo ser expurgadas da escola como metonímia de "um maior aprendizado".

Dos encontros das festividades, pude, através de uma conversa com Cristiano, durante a fila para a merenda escolar, captar elementos daquilo que funcionava como um registro da sua alegria em ensaiar para a performance. Ao assumir funções ativas do processo criativo, ele me relatava que era uma possibilidade de encontro prazeroso:

Eu me envolvo muito quando há atividades artísticas, não só aqui na escola, mas no Baianão, também. Passo horas ensaiando e, às vezes, eu não consigo desligar. Hoje mesmo, enquanto eu vinha de casa pra cá, eu tava ouvindo música, sei lá, daí eu fecho o olho e começo a imaginar um monte de coisas: danças, músicas, roupas. Às vezes, quando eu não me esqueço, eu anoto, mas eu esqueço muito das coisas (Cristiano). 
Esse envolvimento alegre e criativo relatado por Cristiano constitui um momento em que seu corpo se desloca na paisagem curricular e torna-se parte do visível. Tornar- se parte do visível se insere como um modo de lidar com as zonas de abjeção produzidas pela maquinaria escolar, afinal, Cazu e Cristiano eram reconhecidos pelo trabalho executado e, inclusive, eram convocados à participação. Esta forma disputa, junto à normatividade curricular, modos de inclusão, para que corpos gays e negros sejam inteligíveis ao discurso escolar.

Mas, ao mesmo tempo em que ocorre o reconhecimento, isto implica uma qualificação destes corpos que ao serem interpelados como gays e negros ou bichas pretas, inventa-se um padrão, imagina-se um local de identificação que sedentariza fluxos à repetição mecânica de se viver enclausurado no mesmo. O perigo do agenciamento que o currículo mobiliza através das festas escolares é o da indexação que recusa a transformação e as forças do desejo. Em outras palavras, implica tais corpos na representação.

A professora Berenice, em outra ocasião - enquanto assistíamos uma apresentação teatral para a matéria de física -, me diz: "olha como são lindos. Não tem pra ninguém, quando se trata de arte, o gay está anos luz à frente, sinceramente, acho que já nascem com esse talento, é um dom". A frase da professora Berenice é uma produção curiosa da relação entre o currículo e as sexualidades. Comecei a no- 
tar, a partir de conversas com Cazu e Cristiano, que havia uma negociação dos sentidos implicados em seus corpos vinculados à performance, onde eram apresentados como "excelentes alunos".

Havia um jogo entre on/off que solicitava a presença de uma "corporalidade gay" assim que se aproximavam as datas festivas, no entanto, em outros momentos, como relatado por Cazu, "não somos celebridades, tá pensando que é fácil sobreviver aqui? Não é. Eu já pensei em desistir, mas minha mãe cobra isso, quer que eu estude". É nesse sentido que Cazu negociava sua participação em troca de "boas notas" e "reconhecimento" sempre que sua presença era solicitada em eventos escolares.

Essa observação contrapõe um dos mitos apresentados por Deborah Britzman (1996), sobre a privatização da sexualidade como um mito que justifica a política do armário. De fato, a epistemologia do armário, tal como descrita por Sedgwick (2007), está presente em todo o momento de negociação entre estudantes gays e a escola. Contudo, há um vetor de força que tangencia e mobiliza o significado de "bom aluno" a partir do seu envolvimento na esfera pública, isto é, nas festas.

Isso se dá de forma dupla, assim como problematizado por Marlucy Paraíso (2015, p. 50): “um currículo, apesar de ser constituído de muitas formas, pode perfeitamente ser feito da mesma matéria dos sonhos, dos filmes e da vida", e é neste espaço de força que as sexualidades podem deformar 
o currículo em um movimento particular de vibrações singulares. Compreender que este jogo que desenha um mapa de alegrias decalca a sexualidade apenas em termos identitários cujo principal marco regulador, neste território, seja a escola e o currículo, me parece pequeno. Do mesmo modo, celebrar as festividades como um campo de imanência subversivo ao sentido normalizante de um currículo seria ingenuidade.

Esta disputa se inscreve nos interstícios, naquilo que delimita o entendimento das festividades como "locais naturalmente gays", ao passo que forja tais identificações como parâmetros para "bons ou maus alunos" e insere uma fronteira que torna inteligivel tanto as heterossexualidades como as sexualidades dissidentes. Afinal, ao fazer enunciar e ver, o currículo produz (positivamente) um discurso que exerce efeito não apenas sobre garotos gays, mas também esquematiza corporalidades heterossexuais, conforme me relata a professora de Biologia Bianca:

\footnotetext{
Nós não vemos muito os outros meninos [heterossexuais] participando de alguns eventos. Eles acham que dança, poesia e teatro são atividades chatas, ao menos é o que acho. Algumas vezes, um ou outro participa, mas dificilmente dura muito tempo. Os meninos preferem atividades na quadra ou que envolva grafite.
}

A fala da professora Bianca evidencia alguns recursos dos agenciamentos promovidos pelo currículo, pois as atividades corporais, como dança, poesia e teatro, são entendidas comumente como femininas, coisas de meninas. 
Daí que corpos que são heterossexualizados recusam-se à execução, e essa recusa tem como linha de constituição o reconhecimento de atitudes corporais dissidentes que se dá através de um mecanismo que lança luz aos eventos para evidenciar a emergência dos corpos gays.

Estes agenciamentos culminam em um modo de inscrição do desejo e do desejar-se gay a partir do compartilhamento das representações dispostas no território, o que, no limite, acentua a imagem de que os corpos que dançam à luz dos festejos são corpos gays. Isto se dá a partir de uma maquinaria complexa, que envolve aquilo descrito por Deleuze de que toda máquina, além de tudo o que faz, faz ver e falar, culminando naquilo escrito por Foucault (1997, p. 153): “a visibilidade é uma armadilha”.

Contudo, essa tentativa de fixar as sexualidades são contraditórias nas práticas enunciativas, como, por exemplo, ocorreu durante uma observação na aula de Artes. $O$ professor Sérgio, ao dizer que se atrasou para a aula porque foi comprar um urso para sua filha, terminou com "vocês sabem, as meninas adoram ursos!" Obteve como resposta de Lucas, um estudante do primeiro ano do Ensino Médio, "oxe, professor, eu também gosto de urso". A cena gerou um breve constrangimento, e o professor justificou sua fala, se corrigindo. 
Portanto, as festas escolares e as visibilidades por elas mobilizadas podem implicar um mecanismo de poder que incita, a partir de sanções, as corporalidades gays. Essa visibilidade, todavia, é a própria regulação corporal que tenta tornar os corpos reconhecíveis. Assim, voltamos à fantasmagórica imagem que tenta asfixiar o desejo e estabelecer leitos aos fluxos, mas que, na mesma medida, fomenta a emergência de linhas flexíveis para pôr em equilíbrio as descontinuidades.

Destarte, me proponho a pensar a emergência de máquinas desejantes no mesmo circuito de poder, que estabeleçam cortes à paisagem e tracem linhas de fuga ao sentido do reconhecimento. Linhas corporais que correm o campo da diferença, que sejam devires.

\section{Cena II - Fazer a escola fugir}

Por diversas vezes cogitei o fato de que - como uma bicha preta, marcada como tal - eu devesse me dirigir a partir de uma economia identitária e, através dessa economia, operar a lógica disjuntiva de um mundo que tenta nos exterminar. Contudo, assim tentei fazer, mas, desta vez, inscrito numa economia da diferença por perceber que não existe marcador identitário mais forte do que o do homem cis, branco, burguês e cristão e que, ainda assim, não se enxerga como tal, um paradoxo do reconhecimento. 
O perigo de um paradoxo do reconhecimento é que ele afirma a diferença por um lado, e por outro impõe uma moralidade; afinal, algumas características só são singularizadas para "melhor indicar a que ponto o mundo do nativo, em sua naturalidade, em nada coincide com o nosso" (MBEMBE, 2018, p. 157). Assim, os lugares de inteligibilidade produzidos por um currículo também marcam o sentido de uma diferença a ser recusada, do contrário, tenta multiplicá-la, domá-la, reproduzi-la.

28. Nome fictício escolhido pelo estudante.

Em alguns momentos, no decorrer do estudo, fui interpelado por professoras como um modelo a ser seguido por outras estudantes gays e negros. Certa vez, ouvi da coordenadora, durante uma de nossas conversas, que se você não me dissesse que é gay, eu nunca desconfiaria, os alunos precisam disso, você é um exemplo de que é possível. Em outro momento, enquanto alguns garotos e garotas, durante a oficina onde era apresentado um videoclipe da MC Linn da Quebrada, riam e apontavam semelhanças entre Gustavo ${ }^{28}$, um estudante do $1^{\circ}$ ano do Ensino Médio, e a cantora, em uma tentativa de ridicularização, precisei intervir para dialogarmos sobre a atitude da ridicularização. Nisso, um estudante disse: mas você é diferente, professor, você não é como esses viadinhos daqui.

Essas falas que interpelavam o "meu" cotidiano na escola persistiram por dias na minha cabeça. Questões como afinal, por que eu seria o modelo para alguém? Por que eu não sou como os viadinhos dali? (Diário de Campo 
13 de novembro de 2018). A ideia de uma revolta era então capturada no sentido da solidificação do meu corpo no espaço-tempo curricular como a instauração de uma norma naquele colégio, o que diz que os discursos curriculares não simplesmente criam normas e formas de conduta, mas identificam, nas práticas que se afastam da formalidade do texto, novas possibilidades de inteligibilidades para, em seguida, normatizá-las.

Como e a partir de quais posições eu não era visto como "os viadinhos daqui"? Essas questões que se formavam no cotidiano me atravessaram com tal força que, mesmo tentando evitá-las por muito tempo, ora ou outra, elas vinham à tona em diferentes ocasiões. Junto com isso, também era interpelado por pequenos comentários que interrogavam o meu corpo, fazendo-o ceder àquilo descrito por Fanon (2008) como um esquema epidérmico racial, isto é, uma sensação de viver em mim a partir de uma terceira pessoa. "Seu cabelo é tão bonito, deve dar um trabaIhão cuidar"; "olha a roupa que ele usa, parece um africano de verdade"; "ah deve ser muito difícil mesmo, você já é negro, agora imagina ser negro e gay, é uma barra".

Diferente de Gustavo, um aluno negro que era enunciado como "um viadinho", eu não o era. Ocupávamos diferentes posições de sujeito; o meu corpo alçava um modelo a ser seguido, um modelo que dificilmente poderia gerar algum tipo de desconfiança, enquanto o dele, inteligibilizado por regimes de visibilidades intrínsecos na trama curri- 
29. Ver Mbembe (2016, p. 141).

cular da escola, era visto com desconfiança. Essa discussão possibilita instaurar uma superfície para que nos questionemos: até que ponto estudantes negros e gays (bichas pretas) são provocados ao limiar da destruição ${ }^{29}$ para alguma possibilidade de vida na escola?

Visto que, ao se centrar na ideia de um corpo negro e gay como modelo a ser seguido, afirma-se uma identidade universalista implantada no seio da diversidade, como efeito, vemos a produção de "um espaço de violência e de geração de conteúdos dominantes, que não cessa de produzir como ausentes certas vozes para que ecoem outras" (MOMBAÇA, 2017, n.p.). Essa ausência, tal como teorizada por Mombaça, ecoa na provocante pergunta de Mbembe (2001, p. 174): “o que significa violentar para quem não é nada?".

Entretanto, se seguirmos somente a lógica acionada na tentativa da representação, nos paralisaremos nas críticas de um modo único de narrar o cotidiano escolar, retirando, assim, as possibilidades de fuga provocadas no interior desta tentativa de ausentar corpos bichas e pretas de suas singularidades. Se, sobretudo, tratamos de um devir-bicha, isso nos indica que a produção de linhas de fuga concorre aos perigos das linhas de destruição, visto que, para devir, é preciso "passar por um estágio que eles consideram inadmissível: não ser" (TADEU; CORAZZA; ZORDAN, 2004, p. 79). 
Gustavo, assim, ao ser comparado à MC Linn da Quebrada, não se constrange, mas dispara: "acho ridículo isso de achar que se parecer com uma pessoa gay ou travesti é ruim, ela é uma artista, eu adoraria ser como ela" e, logo em seguida, ele aponta o dedo do meio em direção àqueles que riam da comparação. De fato, não sabemos quais os mecanismos disparadores de uma linha de fuga, no entanto, uma vez produzida, ela radicaliza o sentido do movimento em direção a uma desterritorialização. Nesse caso, a fuga de Gustavo não é do mundo, mas seu movimento é uma possibilidade de fazer com que o mundo ou a escola fujam, mesmo que em seguida tudo volte a se reterritorializar, mas jamais será como antes.

Esse movimento também instaura uma zona de indiscernibilidade em que a identidade cede aos fluxos da diferença, isto é, à multiplicidade em que todo o devir se torna possível e o acontecimento é um hiato que coexiste entre o virtual e o atual. Dessa forma, o devir-bicha não é um deixar de ser algo para em seguida se tornar bicha, mas uma parcialidade em que tornar-se bicha nunca é plenamente alcançado, ou melhor, ainda não é alcançado, sendo este ainda um entrelugar.

Contudo, embora não saibamos quais os mecanismos disparadores das linhas de fuga, a bicha é chamada à existência a partir da interpelação, isto é, recorre-se àquilo descrito por Bhabha (1998, p. 46), que "existir é ser chamado à existência", daí que se pode ouvir e ler em distintos 
lugares da escola as palavras bicha!, viado! E é assim que Gustavo é interpelado e é assim, também, que não é preciso necessariamente ser gay para existir enquanto bicha, visto que, cada vez que nomeada/chamada, ela decidirá se tornar ou deixar de sê-la, talvez, por isso, a interpelação seja o próprio mecanismo de escape.

Quando se diz "travesti", "sapatão", "bicha”, dentre outros, neste nomear opera-se uma invocação, como um ritual no qual o que é tido apenas como espírito toma um lugar no chão concreto da experiência. O que era signo materializa-se novamente em corpos que se encontram e se chocam. Invocada e concretizada a situação da bicha pela interpelação, as lutas e embates reassumem um lugar. Lançada nesta paisagem de confrontos, a bicha, nunca completamente constituída então, terá como desafio menos resolver os problemas do que compor ali uma experiência, arranjar uma via para a vida. A ilusão ou relação imaginária implicada pela interpelação não seria, assim, uma máscara que encobriria e deturparia a realidade cientificamente atingível, mas a entrada em um mundo em construção, que nunca está completo e nem é individual, permeado por relações ou tensões diversas. A bicha é máscara, mas o que não é? (ZAMBONI, 2016, p. 76)

As linhas flexíveis que atravessam a escola compõem mapas de intensidades que possibilitam encontros. É importante ressaltar que a escola, enquanto organismo, produz e escuta seus sons, bastando o nosso silêncio para ouvir, como escrevem Guattari e Rolnik (2013, p. 213):

Ouviremos tanto os ruídos grandiosos da grande máquina escolar, quanto o ronco sussurrante das pequenas máquinas 
que estão vibrando o tempo todo em outras sintonias, e que só precisam ser liberadas. Pois é certo que elas estão ali, sempre maquinando para "produzir algo que não exista, produzir uma singularidade na própria existência das coisas, dos pensamentos e das sensibilidades".

Nesse sentido, retomo os questionamentos iniciais para pensar o "meu" corpo imbrincado aos agenciamentos e jogos curriculares que compõem a paisagem escolar. Uma vez que os sentidos dos movimentos cotidianos ocorridos na escola, ainda que acontecessem durante a oficina, mobilizavam fluxos para os corredores, quadras, pátios e banheiros, percebi que eram nestes espaços que ocorriam pequenas insurgências à rotina escolar. Assim, tomo a escola enquanto máquina social, entretanto, povoada por pequenas máquinas que, em seus micromovimentos, provocam microexplosões antes de serem capturadas pelos mecanismos de controle.

Essas pequenas máquinas buscam dimensões afirmativas da existência a partir de uma sensação potencializadora das resistências. Resistir aqui é empregado como invenção para driblar as proibições escolares. Daí que, em conversa posterior com Gustavo, ele me diz: "você não é um viadinho, porque você já está na universidade, quando eu entrar na UFSB, eu quero voltar aqui só para mostrar como eu ainda serei um viado, mas um viado da universidade". 
Para Gustavo, eu não pertencia ao mesmo lugar que ele, embora fossemos ambos negros, ambos assumidamente viados. Esse fato é urgente no sentido de apontar as singularidades e as distinções operadas pela maquinaria escolar em seu sentido de expropriação. Gustavo continua: "você pode fazer o que quiser aqui, ninguém te dirá se tá certo ou errado, igual naquele dia que você falou do seu namorado, você reparou como o povo achou bonito?! Você fala até que é uma bicha preta e ninguém liga [risos]".

A conversa com Gustavo foi muito significativa, uma vez que me fez recordar dos modos como o meu corpo habitava a escola quando eu era o estudante secundarista e como estar ali enquanto pesquisador me deslocava no sentido do que aparentemente era óbvio para as estudantes: eu era o modelo a ser combatido, porque, simplesmente, a máquina escolar me representava enquanto modelo. $O$ fato de estudantes saberem sobre a minha sexualidade me conferia algum movimento, principalmente nos entrelugares da escola e fora dela, mas em sala, no momento da oficina, o "meu" corpo estava indexado a rótulos estereotipados que remetiam a catálogos puros.

Essa ideia de um corpo-modelo-sexualizado a ser dirigido à escola tão logo se apresenta, enfrenta de imediato forças intensivas advindas da heterogeneidade de agenciamentos e jogos de forças, visto que, nos micromovimentos estudantis, o desejo é produzido em microformações desejantes que fazem o suposto bloco homogêneo escolar 
se desintegrar em pequenas moléculas que se proliferam em distintos modos de existir e viver, seja em gêneros, sexualidades ou raças.

Experienciar estes espaços escolares ao lado de e com estudantes me fizeram sentir provocações vibrantes, confundindo, fragmentando e desfazendo um ideário anterior à escola. Os corpos não deixam de se cruzar, de produzir, de conectar-se a outros e maquinar produções desejantes. É este desejo que subjaz à instituição, que subverte a probabilidade, a identidade. Este desejo que multiplica sexos, sexualidades, que faz de "cada um, seus sexos", é que pode, se é que pode, (des)funcionalizar a educação (DELEUZE; GUATTARI, 2010, p. 390). 



\section{4}

\section{"Por que tu me chamas se não me conheces?"! devir-negro em um currículo}

Os desafios da escrita desta seção aconteceram no momento do contato com a literatura pós-crítica em educação. Inicialmente, ao ser selecionado para o mestrado, tudo parecia mais claro e fácil, não que teorizar sobre a negritude seja simples, mas, pela minha própria trajetória e embates políticos, tive uma ideia - errada, por sinal - que o desafio da viagem consistia em uma outra matéria. Baseado em um senso comum do pensamento em educação, tinha, de pronto, a escola como um puro aparelho de reprodução social, por isso, já sabia o que iria encontrar: um local racista, misógino e LGBTfóbico, com padrões opressivos para alunas negras e a extrema dificuldade de elas se manterem neste espaço. 
30. A Lei 10.639 , de 9 janeiro de 2003, altera a Lei . $^{\circ}$ 9.394/96 (Lei de Diretrizes e Bases da Educação Nacional). Esta Lei, sancionada pelo então presidente em exercício, Luiz Inácio Lula da Silva, torna obrigatório, no currículo oficial de todos os estabelecimentos de Ensino Fundamental e Médio, público e privado, o ensino da História da África e da Cultura Afro-brasileira.
Não obstante, era certo para mim que o ponto onde eu deveria chegar estava centrado na Lei $10.639 / 03^{30}$, pois o que faltava a quase todas na educação brasileira era consciência racial, valorizar a negritude para que, assim, a partir desses valores, fôssemos todas alçadas à igualdade. Ou seja, ironicamente, eu estava entrando no mestrado com uma resposta pronta para o meu problema de pesquisa. Em um trecho do meu projeto de pesquisa, havia o seguinte: "Ao reforçar a universalidade e resistir às políticas públicas de equidade, a instituição escolar apenas consagra as desigualdades de origem de cada indivíduo".

Observem, toda a problemática das relações raciais na educação era por mim tratada como um problema exclusivo das educadoras, era meramente uma resistência institucional a algo "maior", isto é, a Lei 10.639/03 e, bastante arrogante, confesso, se as educadoras se permitissem contemplar e praticar as diretrizes dessa Lei, tudo seria sanado. Por que estou revisitando essa trajetória? Parte da literatura que tive acesso estabelece uma superfície de encontro que, a partir de segmentações, estruturam a educação para as relações étnico-raciais de modo linear, com início, meio e um possível fim.

Tais locais se distanciam de um cotidiano de rasgos, incoerências, dilatações e constrições. Algumas vezes, o problema do "negro" - e me refiro ao masculino - está nas imediações de soluções que desconsideram ou fazem pequenas passagens por outras manifestações da negritude. Assim, me parece mais sensato me referir a comunidades negras ou negritudes, assim mesmo, no plural. Não é questão 
de identidade a ordem da vez, mas de pensar as negritudes como formas rizomáticas em detrimento do enraizamento.

No processo de cartografia do Colégio Leonilson, percebi as negritudes como redes encruzilhadas que questionam a universalidade essencialista da "cultura negra" (HALL, 2010). Afinal, diferentes corpos interagiam entre si, produziam paisagens complexas de movimentos e encontros, afetavam-se mutuamente e "contavam uns aos outros histórias híbridas, em parte minhas, em parte tuas, uma parte que está escrita em linguagem de fragmentos e peças mescladas e sem resoluções, em meio a um vocabulário de valores e desejos" (BHABHA, 1998, p. 60, grifo do autor).

Dessa forma, passei a investir meu corpo no interior das paisagens escolares como uma forma de, a partir das linhas de fuga dos corpos estudantis, vislumbrar a invenção de processos de singularizações que correm exteriores à moldura de uma subjetivação massiva. Não há regras universais para se pensar as negritudes, e seria uma violência ética, como escreve Macedo (2006a), acreditar que o grande problema da educação para as relações étnico-raciais seria apenas da ordem do não reconhecimento.

Em meio a toda essa proliferação de novas ideias agenciadas pelos desejos colocados em movimento no campo escolar, algumas alunas inventavam modos de viver outras possibilidades de sexualidades no interior de campos racializados. Mais que a invenção de um local - o que resguarda um aparato de segurança -, pensar as sexualidades implicadas em um jogo racializado tensiona uma tradição epistemológica tanto dos estudos étnicos quanto dos estudos em sexualidades a complexificar e expandir toda uma cartografia. 
Com isso, retomo as discussões trazidas por Bhabha (1998) para quem o significante "negro" está emaranhado em uma rede de saber-poder que traz à tona uma formação coletiva essencializada através de discursos fixadores entre o performativo e o pedagógico. Mbembe (2018, p. 27, grifo do autor) inscreve a política racial como "uma complexa rede de desdobramentos, de incertezas e de equívocos", que tem na raça sua figura central, assim, "só é possível falar de raça numa linguagem fatalmente imperfeita e dúbia".

É a partir dessa linguagem dúbia e imperfeita que gostaria de partir, visto que, ainda que sofram o assédio da fixação, as formas produzidas por quaisquer máquinas sociais são incapazes de apreender por completo o sentido da diferença, assim como suas forças são incapazes de impedir a singularização do corpo negro no interior do próprio sistema de significação. Também, as estratégias de visibilidade negra, as quais, através de critérios representacionais, que buscam tornar a negra visível, evidente e regulada, no momento mesmo de sua efetivação, denunciam sua vulnerabilidade de controle das multiplicidades.

A diferença, portanto, sempre escapa às tentativas de totalização, pois, ao tentar definir o que é ou não negra, criam-se estratégias normatizadoras que buscam instalar fronteiras para que essa definição seja corporificada e repetida incessantemente, produzindo assim identificações. Se é preciso toda esta economia para produzir um sujeito racializado, ele é produzido, portanto, pelas fissuras ocorridas no momento da repetição. Em outras palavras, não se trata do sujeito racializado, mas de um devir-negro que sempre corre, sempre escapa às clausuras das identificações. 
Essa noção de uma repetição corporizada também está presente na ideia abordada por Mbembe (2018, p. 11), na qual,

\footnotetext{
de uma à outra ponta de sua história, o pensamento europeu sempre tendeu a abordar a identidade não em termos de pertencimento mútuo (copertencimento) a um mesmo mundo, mas antes na relação do mesmo com o mesmo, do surgimento do ser e da sua manifestação em seu primeiro ou, ainda, em seu próprio espelho.
}

A ideia de representação que reside no centro da identidade investe sobre os corpos uma tentativa fixadora que, no limite, delimita o que é ou não é um sujeito negro, excluindo, por consequência, a emergência inevitável da diferença que não se pode regular. Daí então que se falar em mau ou bom desempenho de meninos negros, no campo educacional, pode concorrer às regras engendradas no reconhecimento, a partir da norma estabelecida como sanção.

No mais, embora a diferença ${ }^{31}$ se estabeleça como uma força intensiva incapaz de se submeter por completa 31. Neste caso, me refiro a um devir-negro. ao controle, a raça enquanto representação produz efeitos normativos que hora ou outra interpelarão sujeitos racializados que serão coagidos a responder (SOUZA, 1983). Como dito anteriormente, no currículo, embora se adote a expressão "fixar sentidos", esta fixação se dá em torno dos dispositivos de fazer ver, falar e, também, movimentar. E, assim, tais componentes convergem para uma assinatura que homogeneíza os sentidos implicados de uma "identidade negra". 
Tais sentidos, embora inumeráveis, culminam em formas de reconhecimento de uma imagem da identidade que paulatinamente incide sobre corpos negros na escola. Com vista a isso e pensando na impossibilidade de encerramento dos sentidos das negritudes, poder-se-ia abrir margens para pensar se a luta dos movimentos negros pela representação no campo político não seria estéril, afinal de contas, tenho, ao longo deste escrito, tratado dos limites da representação de gêneros, sexualidades e raças no campo cotidiano da escola. A esta questão, acredito que as contestações ocorridas cotidianamente nos diversos espaços atestam os múltiplos sentidos abrangidos pelas lutas negras ao longo da história, como descritas por Munanga (2003), Gomes (2003) e Domingues (2009).

Nenhuma luta, nesse sentido, é em vão, e seria, para dizer o mínimo, absurda qualquer tese que negasse as estratégias políticas adotadas em diferentes tempos por tais movimentos. Além do mais, direito nenhum é cedido pela boa vontade da governação, mas conquistado com muita luta, sangue e suor, como temos testemunhado ao longo da história. Acredito que as disputas no cenário político são travadas na tentativa de fissurar instituições neocoloniais a fim de contar outras narrativas, estas diferentes daquelas que sempre foram de fácil acesso à sociedade brasileira.

Contudo, ao projetar uma identidade como projeto político, não se observa uma desconstrução dos sentidos essencializados, mas sim uma ambivalência do estereótipo, isto é, entre a desconstrução do sentido negativo implicado à negra e uma reafirmação positiva a partir de um empoderamento negro. 
Desse modo, temos, por exemplo, a Lei 10.639/03, que em sentido amplo demanda uma obrigatoriedade de conteúdos que contêm uma outra história do Brasil, a história construída à margem, e que façam referência às figuras transformadoras dos sentidos da humanidade, isto é, uma positivação (valorativa) da negra. Esta crença na obrigatoriedade projeta a identidade negra como objeto pedagógico e, via de regra, encerra possibilidades de emergência de outros sentidos das negritudes.

Dito de outro modo, a identidade negra é "articulada na tensão entre, por um lado, significar o povo como uma presença histórica a priori, um objeto pedagógico, e, por outro lado, construir o povo na performance da narrativa" (BHABHA, 1998, p. 209). Mas, ao fazer da identidade negra um objeto pedagógico que incide sobre o currículo a partir do conteúdo, poderíamos questionar que negra é essa em um currículo negro? Pois, ao partir da ideia de um devir-negro, a anarquia e a ruptura com qualquer definição conceitual que ouse fixar seus sentidos são provocadas pelos movimentos de um vir a ser.

Também, apresentar uma concepção pedagógica de uma identidade negra se vale de percepções e interpretações sobre o corpo, neste caso, substitui a carne (matéria viva) por sua interpretação. A ideia de interpretação concorre à concepção de uma imagem representativa. Nesse sentido, o conteúdo da representação se espraia em teias de reconhecimento e modos de subjetivação que produzem o corpo negro de acordo com uma imagem prévia, narcísica e espelhada, que asfixia possibilidades para a emergência da diferença. 
A ideia de uma identidade negra pré-dada evoca o homogêneo que exclui diferenças mesmo no interior de um conjunto reconhecível, pois qualquer diferença perturba e impõe riscos à repetição performativa de uma identidade. Daí que podemos tensionar a aparição de negras e gays ou bichas pretas na escola, pois é no momento contingente de sua emergência que se dá "testemunho de despossessão da cultura" (BHABHA, 1998, p. 64), visto que, ainda parcial, sua figura é adjetivada como "negra" ou "gay", ou seja, como locais identificatórios que instalam o paradoxo da representação da sexualidade ou da raça, tal como sugerido por Livermon (2008, p. 302), onde, "repousa sobre a racialização do corpo queer como branco e a sexualização do corpo negro como heterossexual".

Por isso, entendo a racialização da sexualidade aqui como "efeito de regimes de regulação normativa que opera na produção de materialidades corporais, conferindo às normas sexuais e de gênero formas diferentes segundo o modo como se entenda a raça" (OLIVEIRA, 2016, p. 224). Ao me atentar para a racialização das sexualidades no currículo, saliento o componente que produz o corpo imaginado da nação, corpo embebido em seios negros que, através, também, do currículo, evoca uma "brasilidade mestiça" que faz corpos se movimentarem ao som de atabaques durante o Novembro Negro como metonímia do próprio corpo nacional.

Dessa forma, minha intenção nesta parte da criação textual é questionar, a partir da cartografia realizada no Colégio Leonilson: como corpos gays e negros (bichas pretas) rasuram a estabilidade de sentidos fixos e dispostos a iden- 
tificações arbitrárias? Para isso, recorri a dois movimentos que ensaiam fugas a partir da encruzilhada de raças e sexualidades, fugas que inscrevem bichas pretas como acontecimentos singulares, que, ao romper com discursos coloniais, desnaturalizam o corpo e questionam uma ficção reguladora heterossexista da nação.

\section{Cena III - O que pode uma bicha preta no Novembro Negro?}

Na escola em estudo, Alberto e Guilherme ${ }^{32}$, ambos do $2^{\circ}$ ano do Ensino Médio, durante uma roda de conversa, disseram que algumas coisas os incomodavam muito nesse ambiente. Guilherme disse que não gostava da merenda nem das aulas de Educação Física, pois se sentia muito constrangido quando era xingado de "viado" por colegas de classe. Alberto acrescentou que, "além de viado, algumas vezes já me chamaram até de macaco". Tereza, aluna do $1^{\circ}$ ano, disse que isso acontecia porque "a sociedade é muito preconceituosa e quanto mais a gente fala livremente da nossa sexualidade, mais ataque a gente sofre".

Alberto é um adolescente gay que mora no Paraguai, bairro periférico de Porto Seguro. Durante a roda de conversa, ele recordou alguns episódios acontecidos durante outros momentos escolares: 
No $9^{\circ}$ ano, quando eu estava vindo para a escola, era de manhãzinha, eu estava de pé no escolar ${ }^{33}$, um garoto me deu uma voadora por trás, daí eu caí no meio do ônibus. Eu não tinha feito nada pra ele, eu só estava conversando e rindo junto com uma amiga. Aquele momento foi muito forte, eu não consigo apagar, sabe?! Ninguém fez nada, ninguém foi me ajudar a levantar, eu fiquei lá com dor e algumas outras pessoas riram daquilo.

Ao questionar Alberto sobre o porquê de aquilo ter acontecido, ele diz que é porque "eu sou gay, hoje em dia eu já me assumi, mas naquela época todo mundo comentava, mas ninguém sabia se eu era ou não. Mas eu sempre fui de rir alto". Guilherme diz se recordar do momento descrito por Alberto e acrescenta: "a gente sofre muito bullying na escola, eu já sofri por ter cabelo crespo também, teve aquele dia, né Guilherme?! Aquele dia que disseram para o pedreiro que ele podia até lixar a parede com o meu cabelo".

Em conversa com a professora Cristina, ela diz que Alberto e Guilherme são estudantes muito "delicados, que durante as aulas não param de falar. Eles andam sempre juntos e conversam mais com as meninas, por isso que os outros meninos ficam fazendo brincadeiras com eles, além disso, eles são muito escandalosos".

Em outro momento, durante a roda de conversa, começamos a falar sobre preferências musicais. Guilherme diz que sua diva pop é a Lady Gaga, "porque ela é fantástica, ela toca, canta, dança, ela é uma artista de verdade". Algumas pessoas na sala riem da empolgação de Guilherme ao falar sobre sua diva pop, mas ele não se importa e pede para co- 
locar um clipe para que possamos ver "a artista que ela é", e acrescenta: "essa música é muito importante pra mim, eu amo a Gaga". Guilherme escolheu a música Born this way ${ }^{34}$, em tradução livre, "Nasci desse jeito", cujo trecho dado ênfase pelo estudante dizia:

Não seja rebaixada, seja uma rainha Seja você pobre ou rica

Seja você negra, branca, parda ou hispânica Seja libanesa ou oriental Mesmo que as dificuldades da vida

Te façam sentir deslocada, provocada ou importunada Exalte e ame a si mesma hoje

Pois, amor, você nasceu desse jeito
33. Ônibus que faz o transporte de estudantes dos bairros para a escola e viceversa.

34. Disponível em: https: //www youtube.com/ watch?v=hlw3pwcpTig

Alberto diz também gostar da Lady Gaga, mas que sua diva pop era a Beyoncé. Questionei o motivo da sua escolha, e ele me respondeu que era porque a Beyoncé representava as pessoas negras e "a luta para que não sejamos excluídos. Professor, ela é a mulher mais poderosa do mundo e é negra, eu ainda me lembro do dia em que ela lançou Lemonade".

Lemonade é um álbum de 2016, que, dentre muitos temas, trata do empoderamento negro a partir de uma poética de alusão a mártires como Malcolm-X e Martin Luther King Jr., à vida de mulheres negras e às lutas raciais por direitos civis no contexto estadunidense. Alberto se referiu à Formation, música do álbum, como um hino e enfatizou o fato da fala de abertura do videoclipe da música ser proferida por Messy Mya, um youtuber gay e negro estadunidense que, após fazer uma série de denúncias contra a polícia, foi morto sob condições suspeitas. 
Alberto e Guilherme são estudantes autodeclarados negros e gays e, ao contrário de Cazu, não gozam de boas notas na escola e costumam ser tratados como indisciplinados, como relata a coordenadora pedagógica Francisca:

\footnotetext{
Olha, eles sofrem muito bullying na escola, eu mesma às vezes preciso intervir, mas assim, eles também provocam. Guilherme é mais delicado, não se mete em tanta briga, mas Alberto se mete, daí já sabe?! Os meninos implicam demais com ele e ele não deixa barato. É complicado tudo isso, mas as professoras também reclamam muito do Alberto, chamam ele de indisciplinado e malcriado, porque ele responde a gente.
}

Para adolescentes racializados (ou não) que performatizam em seus corpos dissidências de sexualidades ou desobediências às normas de gênero, a escola pode ser um espaço extremamente cruel. Ao serem adjetivados como "viados" e "macacos" por colegas, há uma produção de um sujeito específico que evidencia que esta produção não se dá de forma isolada, isto é, o negro ou o gay, mas sim a partir do agenciamento de diferentes discursividades para a produção do abjeto.

Como abjeto podemos entender "algo pelo que alguém sente horror ou repulsa como se fosse poluidor ou impuro, a ponto de ser o contato com isso temido como contaminador e nauseante" (MISKOLCl, 2013, p. 309). Contudo, a produção da abjeção está relacionada a qualquer perturbação em uma identidade normatizada; em outras palavras, a emergência da diferença através de linhas precárias concorre com a formação de máquinas de captura destas contingências. 
Como pesquisador, preciso dizer que estar junto a estes garotos produzia em mim o choro do olhar para o passado e perceber que algumas histórias são marcadas na pele, por vivermos na precariedade de sermos quem podemos ser. Mas, como já frisado neste escrito, meu objetivo maior consiste em cartografar as arenas de insurgências, ainda que dentro de um artefato como o currículo, que prima pela normalização de vidas. Por isso que uma das coisas que mais chamou minha atenção em um primeiro momento foi o fato de Guilherme e Alberto estarem constantemente juntos, uma comunidade de dois que pouco a pouco encontrava outra e mais outra até formar um pequeno motim, fosse no intervalo, na quadra ou na entrada do Colégio.

De fato, o currículo como um artefato cultural ambivalente também é território de encontros, de tramas e de fugas. E é através desses encontros que se produzem agenciamentos em que "os corpos se penetram, se misturam, se transmitem afetos" (DELEUZE; PARNET, 2004, p. 58), produzindo movimentos criadores capazes de resistir aos "poderes estabelecidos que têm a necessidade de nossas tristezas para fazer de nós escravos" (DELEUZE; PARNET, 2004, p. 50). Assim, a amizade de Alberto e Guilherme é um encontro que possibilita emergir o novo, mesmo com um currículo que opera por normas regulatórias.

Essa comunidade de dois, que consistia em Alberto e Guilherme, tão logo se formava, já era outra coisa, um povoamento de multidões. Assim, uma das formas de estancar a multidão estava na separação de ambos, como narra GuiIherme: 
A professora disse que não podemos sentar juntos na aula dela, daí ela colocou o Alberto lá na frente, pra ela ficar de olho [risos] e eu fico lá no cantinho, perto da porta. Eu acho que isso não adianta nada, porque eu converso com outras pessoas. É muito difícil eu prestar atenção em uma aula.

O povoamento de multidões se dava na estratégia de criar outros locais para uma existência bicha e preta, o que indica que a invenção comporta a combinação de elementos heterogêneos que fazem surgir o novo também como estratégia de sobrevivência às violências escolares. Contudo, não se trata de um processo reativo, mas criativo, inclusive com a criação de alianças (LAPOUJADE, 2015).

Talvez, por isso, os locais mais profícuos para encontros no currículo pesquisado foram aqueles distantes das salas de aula, ao menos das aulas formais, daí que os intervalos, o portão escolar, o pátio e os banheiros foram ressignificados como locais para falarem aquilo que em outros lugares não podia ser dito. A sala poderia até separar a partir da distância, mas, nos outros locais, havia os encontros, os embaralhamentos e as penetrações de outras possibilidades, inclusive as de resistência a qualquer forma normatizada de ser.

Assim, por exemplo, Alberto narra o motivo do seu corte de cabelo:

ah, antes aqui só eu tinha um black, todo mundo achava feio e tal, eu recebia apelidos e até a professora uma vez disse que eu devia cortar o cabelo. Hoje em dia, com essa moda toda, todo mundo quer ter cacho, quer ter crespo, eu não quero ser igual, por isso eu cortei. 
Cortar o cabelo para Alberto produziu sua diferenciação às demais, isto é, um modo de habitar o presente a partir das suas marcas das diferenças.

Este excesso que acompanha a trajetória de Guilherme e Alberto, seja a partir da busca pela diferenciação, da criação de locais habitáveis ou mesmo do modo debochado e das risadas altas, consiste em uma "força habilitadora de uma futuridade por vir", como escreve Muñoz (2011, p. 23). $E$ é neste mesmo excesso que podemos visualizar a encruziIhada entre gêneros, raças e sexualidades a partir de performances da negritude, visto que apontam sempre em direção a uma outra possibilidade para os corpos.

Contudo, ainda que aponte para uma futuridade, em muitos momentos, linhas duras, como é o caso da violência racial, corporificam uma relação com a negritude em que ela se torna inteligível a partir do reconhecimento. Assim, a própria negritude é tornada homogênea como marca de uma identidade nacional evocada em alguns momentos escolares, como, por exemplo, no Novembro Negro.

É, pois, no Novembro Negro que algumas marcas se instituem com força tal que instauram mundos e fluxos culturais diversos que atravessam o currículo. Dessa forma, no currículo da escola estudada neste texto, a celebração do dia 20 de Novembro é um acontecimento recente, mobilizado por algumas professoras em parcerias com sujeitos fora da escola, e é nesse mesmo momento em que ocorre a produção de corpos agenciados por forças incapazes de erradicar a diferença, ainda que muito se empenhe. 
Essa observação está em consonância à crítica que Paul Gilroy (2006, p. 65) traça à política negra moderna que "esteve mais interessada na relação da identidade com as raízes e o enraizamento". Não era raro, durante os preparativos para o evento, visualizar que os enunciados apresentados como possibilidades artísticas se encerravam em imagens daquilo que se costumou reconhecer como a "cultura negra”, isto é, axé, samba, carnaval, capoeira, Lázaro Ramos e Taís Araújo, futebol, funk e hip-hop.

Por óbvio, tais manifestações são imagens das resistências negras por toda a história brasileira e em diáspora, como já demonstrado por Wlamyra Albuquerque e Walter Fraga Filho (2006). Essas manifestações ainda são produtos de embates culturais que não devem ser vistas como ações inscritas apenas na lápide fixa da tradição, mas como processos cujas negociações complexas conferem certa autoridade "através das condições de contingência e contraditoriedade que presidem sobre as vidas dos que estão "na minoria'" (BHABHA, 1998, p. 21). Ademais, o reconhecimento do axé, samba, carnaval e capoeira como manifestações negras gera uma forma parcial de identificação, contudo, reificada a partir de outras temporalidades no ato da repetição da tradição.

Mas, a ideia de uma essência evocada pelo currículo a partir dessas manifestações desloca e engendra um universalismo limitante à imaginação e reduz histórias heterogêneas a uma única identidade em detrimento de movimentos, conflitos e hibridismos. Alberto e Guilherme confundem 
essa "essência" ao se produzirem em encruzilhadas que interagem com diferentes identidades e se deslocam de acordos feitos sem as suas presenças.

Em uma conversa durante o caminho da escola até o ponto do escolar, Alberto me diz que "a professora queria que eu participasse do Novembro Negro, ia me dar até ponto extra, mas eu não sei dançar pagodão e nem jogar capoeira, então eu vou fazer o quê lá? Não dá pra eu fazer a coreografia de Single Ladies [risos]". Essa fala de Alberto nos fornece um rico material para a produção de um campo que apenas recentemente, com o advento de pesquisas que relacionam negritudes e dissidências sexuais, tem ganhado relevância, isto é, uma denúncia da forma heteronormativa que conduz os estudos das negritudes.

Nesse sentido, o currículo inscreve alguns corpos a partir de suas normas em um além. De acordo com Homi Bhabha (1998, p. 27), o além é um espaço intermediário que localiza o corpo em uma temporalidade revisionária, isto é, desloca-se ao "presente para reinscrever nossa contemporaneidade cultural [...] tocar o futuro em seu lado de cá" para intervir e inventar no aqui e no agora.

Ao evocar a presença de uma coreografía de uma cantora pop em um evento que homenageia a resistência negra, o estudante se sente deslocado como se a diáspora negra não se desse também em campos dissidentes sexuais, ainda que anteriormente ele tenha mencionado o fato da militância da sua diva pop pelas causas raciais. Contudo, chegado o dia do evento, a fotografia de Beyoncé estava fixada em um papel madeira, em um dos corredores da escola, como 
"personalidades negras", junto a outras artistas. E, na parede ao lado, estavam coladas figuras de acarajés, mães e pais de santo e uma cartolina com os nomes de alguns Orixás e sínteses das suas histórias.

As representações dispostas na escola nos fazem questionar que negra é esse no currículo negro?, pois há uma visibilidade de uma manifestação da negritude em que se revela escravidão, assassinatos, mártires e brutalizações formando um gradiente visual que fixa corpos negros em determinados pontos como efeito daquilo descrito por Hartmann (1997, p. 57), de que "o caráter dado da negritude é resultado de uma corporalização brutal do corpo e uma fixação de suas partes constituintes como índices da verdade e do significado racial".

Ao final do primeiro dia do evento, que teve um total de dois dias, Alberto e Guilherme se juntaram com mais duas colegas, Fernanda e Carina, e fizeram uma apresentação em homenagem a Marielle Franco, vereadora do estado do Rio de Janeiro, assassinada por milicianos em 14 de março de 2018. Na ocasião, elas leram dois textos, sendo um deles da escritora Conceição Evaristo, e o outro de Carolina Maria de Jesus, enquanto fotografias de manifestações das negritudes eram apresentadas em slide.

A constituição da performance apresentada durante o Novembro Negro marca significativamente uma experiência que inscreve a corporalidade negra marcada pela violência racial como efeito de autenticidade da negritude, ainda que o desejo exposto por Alberto estivesse na produção de uma performance com alguma música coreografada da Beyoncé. 
A violência racial, assim como as desigualdades sociais que assolam majoritariamente as populações negras, é performada como possibilidade de se conferir inteligibilidade à negritude mobilizada pela máquina curricular.

Assim, quando Alberto e Guilherme performatizam tais efeitos, o que se assume é o mecanismo contingencial e precário das relações de poder dispostas no currículo da escola em comento, visto que estes sujeitos "negros" e "gays" não são dados a priori, mas produzidos em uma superfície de negociação com o desejo do outro. Daí que a corporificação da violência racial se dá como uma cicatriz que tem como efeito de verdade a produção de uma repetição com inusitados rasgos da diferença.

Cortar o cabelo, como explicitado por Alberto, é uma fuga, contudo, para tornar-se inteligível, novamente se renegocia o corpo negro com a violência e a brutalização, como possibilidade de produzir visibilidade do racismo como uma marca colonial. Dessa forma, a memória da escravização dos povos africanos e a exploração e extermínio dos povos afro- diaspóricos são mantidas como locais próprios da verdade de toda a negritude, de modo que não haja, nesses termos, sentidos das negritudes apartados da escravidão.

O currículo em debate marca, durante o Novembro Negro, a escravidão como elemento central na constituição de uma negritude que se evidencia pela chibata e os grilhões e materializa-se na exibição obscena de imagens da tortura, como se fosse possível representar o acontecimento. Hartmann (1997) define como rosário dos horrores uma certa 
maneira de narrar a história a partir da violência que acarreta a produção de efeitos de verdade, e a vivência de corpos negros e gays interpelam esses efeitos a partir de outras potencialidades imaginativas.

As potencialidades imaginativas de bichas pretas reinscrevem a linguagem cruel do currículo que nos produz como sujeitos de certo tipo e que diz como devemos agir em certas condições para sermos aquilo que querem que sejamos. Trago a crueldade como uma força que engendra formas, isto é, formas de agir, de ser, de viver e de estar, e que também, paradoxalmente, fornece elementos potentes para pensarmos em uma estética da resistência diante do atrofiamento de um currículo.

A comunidade povoada de multidões a qual Alberto, Guilherme e outros corpos estudantis criam abre disrupções para as marcas de uma memória gerida por intermédio da violência. Ainda que não se ignore o modo como ora ou outra estas violências interpelarão seus corpos, as criações possibilitam o agenciamento de formas de vivenciar a dor da travessia do Atlântico para ressurgir como algo parcial e volátil.

Nesse sentido, os acontecimentos produzidos por um devir-negro e devir-bicha sabotam as narrativas, pois imergem na experiência e voltam como sendo outra coisa, sem de nada se apropriar ou reproduzir, porém com força tal para a criação de uma bicharia negra no centro da cicatriz. Tais linhas são de dores e prazeres que comportam os terrores do contato com a violência e o morrer ao multiplicar-se. 
Um devir-negro fura o mundo constituído pelas normas, escapa pelas arestas que ousam assediar os sentidos da vida a partir da anulação das possibilidades de alegria; contudo, as normas não deixam de ser produzidas, a territorialização e a reterritoralização são constituintes dos corpos que tentam se desterritorializar.

Porém, estes acontecimentos não marcam as relações raciais e sexuais como simétricas, sabemos que há diferenças de forças e intensidades, e qualquer norma, por mais bem-intencionada que seja, objetiva por fim a exclusão da diferença. Um devir jamais se presta à fantasia colonial da possessão do outro, da extração arbitrária de um constituinte revolucionário em que diferentes elementos sejam simétricos, ao contrário, é da assimetria que se planeja a fuga.

Se um currículo é por excelência um instituidor de formas - formas sexualizadas, racializadas, generificadas, infantis, juvenis, docentes e discentes -, significa que nele também vivemos de alguma forma, sabotamos as formas instituídas e, pelas formas, somos informados. Elas também nos igualam e cessam conflitos por buscarem a exclusão da diferença. Ao final, é possível verificar em muitas diretrizes que as "formas são odes do espírito humano à facilidade" (CORAZZA, 2010, p. 81).

A fuga se faz enquanto um procedimento de tornar-se estranho às formas, ainda que, muitas vezes, elas sejam desejadas. Tornar-se estranho é deslocar-se, ser um nômade que confunde as localizações entre o público e o privado, a escola e o mundo, o eu e o outro. "O momento do estranho relaciona as ambivalências traumáticas de uma história pessoal, psíquica, às disjunções mais amplas da existência política" (BHABHA, 1998, p. 32). 
Na próxima cena, trago resquícios de campo para pensarmos a fuga como possibilidade criativa das existências bichas e pretas no currículo escolar.

\section{Cena IV - "O now-frágil" (ou a tarefa de um fugitivo)}

Durante a imersão no Colégio Leonilson, muitas foram as cenas que proporcionaram debates e discussões nos momentos das oficinas. Muitas das discussões nasciam a partir de elementos advindos das mídias sociais (Facebook, Instagram, Twitter) e de calorosas discussões sobre direitos LGBT, das mulheres e de negros até pautas como apropriação cultural, representatividade e performances que envolviam nudez.

Certo dia, durante uma atividade que tinha como tarefa que as estudantes levassem produções artísticas de pessoas negras, José, uma das poucas estudantes que professava sua religião, o Candomblé, publicamente na sala, apresentou uma canção. Diferente das outras estudantes, ele optou por fazer uma versão da música, levando seu violão. José não estava matriculado na oficina, contudo, algumas vezes entrava para "fugir do reforço de português, que é uó, profs".

35. Disponível em: https://www. youtube.com/ watch?v=XqYuC4i090I.
Ele então pediu para apresentar uma música, sentou-se ao meio do semicírculo em que estávamos e, tocando o seu violão, cantou a música lodo + Now Frágil ${ }^{35}$, das artistas Luedji Luna e Tatiana Nascimento. Pela força da canção, transcrevo ao lado a letra da música: 
Me arde o sal Me arde o sal Me espalha o sal

Me espelha o mar

Me acolhe o mar Me abraça o mar Me afaga o mar Me afoga o mar Me afunda o mar Me morre o mar Me a funda dor Fundo de nau

Funda turva escura dura Funda dura tumba escura

Corta o vento cala chuva

Orí zonte é todo sal

É todo longe É todo mágua É todo roubo Colonial

Não há cura, morto tomba (Dom esconde)

A pele escura

Egungun Bom

(De voar)

E evadir

A turba alva Aos tubarões Y os porões Do alto Mergulhar

Y naufrágio

Y now frágil, frágil, frágil

O mágico da diáspora:

Des

Membrar terra-chão

Mas se eu já fui trovão Que nada desfez

Eu sei ser Trovão

Que nada desfaz, nem

O capataz

Nem a solidão

Nem estupro corretivo contra

Sapatão 
Os complexos de contenção

Hospício é a mesma coisa que presídio é a mesma coisa que

Escola é a mesma coisa que prisão que a mesma coisa de hospício

É a mesma coisa que

As políticas Uterinas

De extermínio

Dum povo que não é Reconhecido como civilização

(Mas eu sei ser trovão $\mathrm{E}$ se eu sei ser trovão Que nada desfez

Eu vou ser trovão Que nada des Faz)

M

Nem a solidão Nem o capataz

Estupro corretivo contra Sapatão a loucura da Solidão capataz queimarem

A herança De minhas Ancestrais Arrastarem Cláudia

Pelo camburão Caveirão

111 Tiros contra

5 Corpos

111 Corpos Mortos

Na prisão

Eu sei ser trovão? Que nada desfez?

Eu já fui trovão e se eu já fui trovão eu sei ser trovão!

Eu sei ser trovão que nada Nada

Desfaz

Epahey oyá!

Eu sei ser Trovão

E nada Me desfaz 
José se afirma enquanto um aluno gay, negro e candomblecista. Em rodas de conversa, ele falava sobre a visão da sua religião para com os corpos dissidentes sexuais, dizendo ser comum que homens gays frequentassem o terreiro e que o seu babalorixá também era um homem gay.

A produção de um momento em que há inúmeras forças de atravessamento na sala abriu possibilidades para conversas outras que multiplicavam as paisagens da sala de aula. A convocação da arte como um modo de inscrição em que sujeitos rasgam a paisagem para se dissolver em fantasias possibilita a perda, ao menos momentânea, das formas do Mundo. Trata-se, assim, de pensar a diáspora negra através de procedimentos de fuga em que corpos são fugitivos e que, como escreve José Gadelha (2018, p. 174), “o fugitivo é aquele que não se localiza na paisagem ao mesmo tempo em que ele a compõe [...] nada a ver, nada a dizer e tudo a acontecer são os lemas dos que fogem".

Dessa forma, a arte é um importante mecanismo para acoplamentos, torções e produções de encontros na escola, visto que se instaura enquanto rizomática e gera campos de força para um devir-negro que se agencia coletivamente para fora das paisagens estruturadas do currículo. Essa explosão que toma todas as direções serve-se de potências ressonantes ao devir, uma vez que não anula nenhuma singularidade das forças encontrantes.

José, após sua performance da música, nos diz que "ser preto é, muitas vezes, se sentir sem um lugar, porque tem muita gente que acha a gente feio, e a gente mesmo 
36. Quando se fala em figural, compreendese, a partir da obra de Deleuze e Guattari (2012, v. 2), aquilo que não rostifica algo, isto é, que não confere uma identidade total e fixa de algo ou alguém, ao contrário, pode até servir para constituir parcialmente, mas não para identificar. passa a se achar esquisito, mas que nossa ancestralidade tá aqui do nosso lado". Habitar o mundo com outros mundos a partir da sabotagem da localização é o que, cotidianamente, vemos e sentimos nas escolas. Essa necessidade de criar locais efêmeros traça determinadas linhas que alcançam uma potência figura ${ }^{36}$. Corpos negros e gays, na escola, experimentam o (des)caminho por espaços-tempo encruzilhados, rizomas diaspóricos que fornecem elementos de fuga.

Tais fugas são acompanhadas por raízes pivotantes, visto que ora ou outra desprendem-se do rizoma para "sobreviver" à tarefa do contato com as marcas coloniais que o racismo imprime na pele profunda. Este movimento ocorre numa circularidade, onde nem o verdadeiro nem o falso estão em questão, mas sim uma produção de novos diálogos com o já existente e a possibilidade da criação para além dos sentidos modernos do que é (ou não) ser negro.

Implicar os sentidos da negritude à Modernidade está inscrito, sobretudo, naquilo que Mbembe (2018) traz como o significante vazio que se torna potente transformador da figura do "outro". O "outro" onde nada se vê, nada se compreende e nada se quer compreender, visto que, nos processos pelos quais as políticas públicas se adequam a um contexto neoliberal, a negra se torna a cripta viva do capital, onde sua existência é aprisionada através das ordens do mercado.

Ao resistir às formas instituídas do Ser, o que bichas pretas propõem à escola é uma conversa a partir das fronteiras, onde "a fronteira se torna o lugar a partir do qual algo começa a se fazer presente em um movimento não dissimilar 
ao da articulação ambulante, ambivalente" (BHABHA, 1998, p. 24). Assim, oposicionalismos duros e polarizações arbitrárias cedem às margens confusas das existências que se atravessam.

Essa resistência, que se coloca como se produzida por um "mágico da diáspora" e também como um trabalho fronteiriço entre classes, raças e sexualidades, fornece materialidade para o novo, algo que habita um entrelugar do passado e do presente. Este novo é espaço-tempo de "atos insurgentes de tradução cultural" (BHABHA, 1998, p. 27, grifos do autor) que, também, produzem currículos no interior do currículo, pois traduzem o passado nas reconfigurações dos entrelugares curriculares.

O naufrágio de José retoma as marcas do escravismo e seu rosário dos horrores, mas o inova na performance em que "o passado-presente torna-se parte da necessidade, e não da nostalgia, de viver" (BHABHA, 1998, p. 27). Assim, o espaço-tempo curricular é tensionado pelas velocidades das linhas daqueles que são os fugitivos, por isso são tão complexas as relações na escola. As linhas vão e voltam, circulam, percorrem ziguezagues, se encontram e multiplicam.

A representação, embora esteja instalada e pronta para a captura, sofre os efeitos das intensidades, uma vez que, para os fugitivos, as fronteiras sempre serão locais a serem eliminados, pois o que é perder o Mundo para aqueles que nunca o tiveram? O que é a rostidade para sujeitos forçados a fabricar possibilidades de sobrevivências onde a máquina-escola corta gente a todo momento? 
Sobre "cortar gente", José, em outro momento, comenta: "vixe, muita gente já desistiu, tem gente que tem que trabalhar pra ajudar em casa, outros desistem pelo bullying, uns morrem, outros reprovam uma, duas, três vezes e desistem. Habitar as linhas fronteiriças do currículo é muitas vezes jogar o jogo do extermínio nos riscos do devir, pois as mesmas linhas que instauram fugas também são linhas de destruição. Nesse sentido, as fronteiras são habitadas também pelas refugiadas.

As refugiadas são aquelas a quem o Mundo permite que morram afogadas nos oceanos, mas também as que são deportadas. Deportar na escola significa uma sentença que diz que "você não serve para nada naquele mundo que the fecha as portas, deportar consiste no contrapassaporte da vida, uma sentença de que você já está morto para determinado mundo que comumente se pensa como Mundo" (GADELHA, 2018, p. 178).

Mas, mesmo sob o risco da deportação curricular, um fugitivo sempre foge, sempre expande as fronteiras, pois a tarefa de um fugitivo

é não vibrar para o Mundo, não se deixar consumir pelo capital. Ser tocado por alguma potência de vida e vibrar com ela em uma esfera alheia do Mundo, por uma "linha de fuga", no sentido mais amplo daquele velho sentido da filosofia de Gilles Deleuze, porque os sujeitos fugitivos não fazem de sua fuga um simples meio de campo entre a Norma e o modo com que efetivamente se foge dela. Não se trata de desregular o funcionamento de organismos que regulam a vida e com os quais, em outro momento da vida, o fugitivo pode voltar a viver pacificamente ou simplesmente pode voltar a viver como vivia anteriormente. A condição do fugitivo é de sempre estar bolando novas fugas. Caso contrário, ele morre (GADELHA, 2018, p. 181). 
Dessa forma, retorno a algumas problematizações trazidas no início desta seção-paisagem, onde, de certa forma, tentei apontar limites no conceito de representação trazidos no cerne de alguns movimentos, inclusive naqueles que resultaram na Lei 10.639/03. Ao criticar políticas representacionais, o que tento fazer é não tomar a negritude enquanto puramente forma expressa em metanarrativas, visto que todas as formas que compõem um currículo são resultantes de campos de força fabricados em jogos múltiplos e muitos concretos que conferem inteligibilidade à vida a partir das suas formas.

Nesse sentido, a guerra travada pelos movimentos negros e LGBTs, pela afirmação de possibilidades de vida e humanidade, provém de uma guerra anterior que se travou contra corpos negros e LGBTs. Assim, tais movimentos inauguram uma ação com suas singularidades; contudo, como agentes desta mesma ação, não podem controlar o seu resultado, pois este se vale de um contato com o Fora:

O Fora é um espaço de singularidades, de matérias não formadas, funções sem nenhum tipo de formalização, forças sem estratificações, fluxos não capturados, pura virtualidade da vida. É aquilo que não permite as coisas se assentarem, se territorializarem, e que persiste, insiste e subsiste no meio delas, mantendo vivo o movimento desterritorializante das forças que virtualizam a existência. As próprias linhas que separam os territórios de uma forma de vida do Fora estão continuamente em fluxo. A vida não para de brotar por todos os lados. Fora: O incriado! O indomável! Oh, sim! (OLIVEIRA, 2012, p. 95). 
As cenas grafadas aqui colocam sob suspeita o currículo, visto que esse, como o conhecemos, institucionaliza o embate de forças do Fora, das singularidades e das multiplicidades das diferenças raciais e sexuais dentro de si para manter alguma coerência. Também, através dessa busca por coerências das formas, corpos estranhos a elas tornam-se fugitivos, visto que, ao disseminar formas de vida, o currículo se vale de formas únicas, centradas, indivisíveis, tal como o sujeito da Modernidade. Muitas vezes, estes movimentos se inscrevem enquanto caridosos, lotados de boa vontade aos diferentes e suas diferenças, mas, ao encerrar as multiplicidades, o quanto de crueldade bem-intencionada se pode fazer? O quanto de crueldade se é usada para fabricar a escola tal como a conhecemos? 
豆 



\section{Notas de um quase fim}

Parece-me tentador que neste momento eu tente explicar não apenas o percurso, mas os motivos de cada seção, assim como as nuances e pequenos percalços do ato de investigar. Uma tentativa de justificar a importância de discutir sobre corpos racializados e dissidentes sexuais no currículo. Parece-me também tentador que eu concorra a maneiras de prescrever atitudes que marquem positivamente a educação, que professe formas emancipatórias das ações escolares e assim promover um efeito de catarse narcísica.

De fato, corri linhas de um pensamento da multiplicidade através da filosofia da diferença, talvez este tenha sido o encontro mais violento instaurado até este momento na minha vida acadêmica. Molhei meus pés neste líquido viscoso para ir além de mim, ainda que curtos tenham sido os passos que dei. Contudo, a escrita é um campo aberto, e acredito não caber a mim a possibilidade de fechá-lo, de entregar aquilo que chamamos "desfecho". 
Embora a escrita deste texto corra através de construtos tais como gêneros, raças e sexualidades, com uma marcação significativa aos corpos bichas e pretas na paisagem curricular, o movimento da diferença ensaia uma quebra à identidade que se arrasta desde a Modernidade como griIhões. Assim, os currículos e, mais precisamente, o currículo da escola aqui discutida, atuam na constante produção de formas inteligíveis de reconhecimento e nomeação. Essa produção curricular é marcada por jogos de poder, hibridismos e assimetrias.

Ao mesmo tempo em que os jogos de poder são jogados e corpos são produzidos, novas personagens viram a mesa, mudam as regras, recusam-se a jogar o jogo da inteligibilidade e, por isso, bagunçam tudo, mudam objetos de lugares. Mas, decerto, há "tanto uma vontade de forma, de adestramento, como também uma vontade de afirmação, de construção, de criação e expansão da vida" nestes jogos (OLIVEIRA; PARAíso, 2013, p. 643).

Temos acompanhado, no Brasil, um movimento deveras malicioso que insiste em implantar uma moral escolar baseada em preceitos conservadores e neoliberais, onde, cada vez mais, somos bombardeados por informações que nos furtam a experiência de sentir a escola, mais que interpretá-la. Estes movimentos que ascendem vertiginosamente atingem todas as camadas do pensamento educacional e conferem movimentos perigosos às políticas curriculares.

37. Ver Corazza (2016).

E são esses movimentos perigosos que flertam com lógicas absolutistas e arbitrárias que nos lançam em um terror segmentarizado ${ }^{37}$ cujos efeitos nos fazem padecer em "fascínio pela megamáquina capitalística e planetária" (CO- 
RAZZA, 2016, p. 136). Ademais, este mesmo fascínio de uma humanidade vivivel interroga através das suas normas as esferas do reconhecimento daquelas/es que não as vivem.

O trabalho desenvolvido neste texto não ocorre no sentido que caminha de um não saber para um saber e/ou que nos apura para um melhor entendimento do cotidiano escolar, o que busco é o tecer na superfície, pois apenas nela encontramos os movimentos necessários para mobilizar aquilo que nos parecia estagnado, nela também vivificamos as paisagens e estranhamos o currículo.

Na superfície escolar podemos ter encontros potentes para a produção de violências do pensar, violências que nos deslocam do sentido primeiro cogitado ainda na comodidade da crítica pela crítica. Nesse sentido, compor este estudo e análise passa, sobretudo, pelo embate contra os velhos manuais de prescrições das condutas, sendo necessário, assim, formular e remodificar e deixar-se penetrar pelas forças que se intensificam no encontro dos corpos.

Para quem se aventura a adentrar em uma escola, em uma sala de aula, como foi o meu caso, a vivência extravasa as formas e os conteúdos, tornando-se outra qualquer coisa, sempre parcial, sempre prestes a tornar-se, como que à beira de um abismo. A escolha da arte como método de inscrição na escola a partir das oficinas passa pela experiência possibilitada pelo campo, mas também pela experimentação dos prazeres que nos permitem um compartilhamento das sensações dos mundos escolares. 
Com isso, não pretendo reduzir a experiência a subjetivismos, os acontecimentos não são diversos simplesmente porque somos diferentes, caso considerasse isso verdade, reproduziria a lógica moderna em que cada sujeito é centrado, estável e formado. Assim, as experiências diferem na relação em que cada corpo se dobra sobre si mesmo e tem acesso às sensações daquilo que pode ver e daquilo que pode pensar naquele momento, inventando suas maneiras de habitar a escola.

Ao encarar esta criação textual como obra aberta, recuso-me a conferir sentidos definitivos a qualquer elemento aqui tratado, uma vez que tudo aquilo que ousei escrever é acompanhado na justa medida por aquilo que silenciei, habitar as zonas de encontro na escola se faz acompanhada daquilo que não é possível descrever, que é pura sensação ininteligível.

Ao escrever fui múltiplas forças e personagens, pois em mim transpassam cheiros, sabores, gestos, olhares e algo que vaza a tudo isso, um terceiro elemento da escrita com vibrações incapazes de serem captadas. A dúvida permanece como um esqueleto que se forma junto ao meu, um esqueleto de dúvida e medo, como na personagem Bica, de Conceição Evaristo (2015, p. 100), para a qual o medo não a faz recuar, "pelo contrário, avanço mais e mais na mesma proporção desse medo. É como se o medo fosse uma coragem ao contrário. Medo, coragem, medo, coragemedo, coragemedo de dor e pânico". 
Qual dicionário negro entende a palavra amor do mesmo modo que compreendeu a palavra medo? E quando a negritude está envolvida pela feitiçaria da bicharia, qual o gesto ríspido se inscreve nas mãos daqueles que a pacto de sangue juraram que "a gente combinamos de não morrer"? (EVARISTO, 2015, p. 99). E se a gente combinamos de não morrer, por que, também, não combinamos de não nos matar? De inverter a ordem discursiva das instituições neocoIoniais eurocêntricas possuídas de uma brancura patriarcal feitas para nos suicidar lentamente em lugares de subalternidade?

O Ocidente, pensado sob a valoração da brancura e da heterossexualidade, invalida da sua gramática o corpo-negro, o corpo-bicha, e não a somatória dos dois anteriores, mas o espaço híbrido que resulta no ainda impensado corpo-negro-bicha. A intenção aqui foi tomar este corpo, que é o espaço pelo qual me movimento, como o ponto da diferença, daquilo que deixo de ser (SILVA, 2007). O espaço entre a bicharia e a negritude que, ao se tornar referente, fende a universalidade e borra uma identidade autorreferente.

Negritude e bicharia aqui são feitiços tecnológicos que se acoplam ao corpo para a produção de um sujeito que tem como exercício a própria reinvenção através da expressão de suas marcas. Um conjunto movediço de discursos que tentam apreender corpos tal como se represa águas. Contudo, dadas as infinitas possibilidades de existências, os sujeitos contestam, negociam, resistem e reconduzem direcionamentos normalizantes e transbordam as margens. 
Com isso, não foi minha intenção negar os aparatos coercitivos e as violências física e simbólica que operam no cotidiano escolar, mas assumir outra perspectiva, esta não mais centrada no sujeito hegemônico ou nas estratégias pelas quais viabilizam a homofobia e o racismo, mas nas fricções que possibilitam fugas, entrecruzamentos e hibridez. Afinal, "ser bicha não é só dar o cu / É também poder resistir".

38. Excerto da música "Bixa Preta", composta e interpretada pela Mc Linn da Quebrada. Disponível em: https://www. youtube.com/watch?$v=V y r Q P j G O b b Y$
Esse deslocamento também não pressupõe papéis dados de vítima ou algoz, apenas sugere o distanciamento de uma visão essencialista que busca uma verdade absoluta sobre os sujeitos. Também, realoca a possibilidade de um corpo político constituído na/pela diferença, isto é, um corpo agonizante em constante devir que se identifica, mas também se nega, que substitui o ou para o e, rebolando pelas fronteiras e metralhando normas, como canta a MC Linn da Quebrada ${ }^{38}$ :

\author{
Bixa preta! \\ Trá-Trá-Trá-Trá Bixa preta! \\ Trá-Trá-Trá-Trá-Trá \\ A minha pele preta é meu manto de coragem \\ Impulsiona o movimento \\ Envaidece a viadagem Vai desce, desce, \\ desce Desce a viadagem!
}

Assim, a bicha preta, a partir do seu local enunciativo, provoca no adjetivo "preta" a onomatopeia de uma metraIhadora. Não mais é um pejorativo ou algo que se constitui como um mecanismo de constrangimento é, ao contrário, 
uma sonoridade que se funde à carne e produz incômodos às normas de gêneros e ao dispositivo racial implantados no currículo, pois não apenas se faz capturar tanto pela negritude e homossexualidade, mas assimila e distorce significante e significado. 


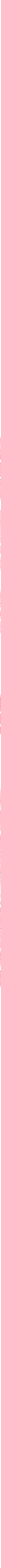




\section{referências}

ALBUQUERQUE, Wlamyra R. de; FRAGA FILHO, Walter. Uma história do negro no Brasil. Salvador: Centro de Estudos Afro-Orientais; Brasília: Fundação Cultural Palmares, 2006.

ANZALDÚA, Gloria. Como domar uma língua selvagem. Cadernos de Letras da UFF, Niterói, n. 39, p. 305-318, 2009.

BENEDITTI, Sandra Cristina G. Máquina. In: CORAZZA, Sandra M.; AQUINO, Júlio G. Abecedário: educação da diferença. Campinas: Papirus, 2009. p. 72-73.

BHABHA, Homi K. O local da cultura. 3. ed. Belo Horizonte: Editora UFMG, 1998.

BRITZMAN, Deborah. Curiosidade, sexualidade e currículo. In: LOURO, Guacira Lopes. O corpo educado: pedagogias da sexualidade. Belo Horizonte: Autêntica, 2010. p. 83-112.

BRITZMAN, Deborah. O que é esta coisa chamada amor: identidade homossexual, educação e currículo. Educação e Realidade, v, 21, n. 1, jan.jun. 1996. p. 71-96.

BRITZMAN, Deborah. Sexualidade e cidadania democrática. In: SILVA, Luiz Heron. A escola cidadã no contexto da globalização. Petrópolis: Vozes, 1998.

CARVALHO, Maria Inez. O a-con-tecer de uma formação. Rev. FAEEBA - Ed. e Contemp., Salvador, v. 17, n. 30, p. 159-168, 2008. 
CESAR, Ana Cristina. A teus pés. São Paulo: Editora Companhia das Letras, 2016.

COATES, Ta-Nehisi. Entre o mundo e eu. Rio de Janeiro: Objetiva, 2015.

CORAZZA, Sandra Mara. A educação no século XXI: desafio da diferença pura. Ariús, Campina Grande, v. 15, n. 1, p. 9-16, jan./jun. 2009.

CORAZZA, Sandra Mara. Base Nacional Comum Curricular: apontamentos crítico-clínicos e um trampolim. Educação, Porto Alegre, v. 39, n. esp., p. 135-144, dez., 2016.

CORAZZA, Sandra Mara. O que quer um currículo?: pesquisas pós-críticas em educação. Petrópolis: Vozes, 2001.

CORAZZA, Sandra Mara. Pedagogia dos sentidos: a infância informe no método Valéry-Deleuze. In: KOHAN, Walter. (org). Devir-criança da filosofia: infância da educação. Belo Horizonte: Autêntica, 2010.

CORAZZA, Sandra Mara. O que se transcria em educação? Porto Alegre: Doisa, 2013.

DELEUZE, Gilles. A Imanência: uma vida...Terceira margem, Rio de Janeiro, ano 9, n. 11, p. 160-164, 2004.

DELEUZE, Gilles. Em que a filosofia pode servir a matemáticos e mesmo a músicos. Educação e realidade, Porto Alegre, v. 27, n. 2, p. 225-226, jul./ dez. 2002.

DELEUZE, Gilles; GUATTARI, Félix. Kafka: por uma literatura menor. Rio de Janeiro: Imago, 1997.

DELEUZE, Gilles; GUATTARI, Félix. Mil Platôs: capitalismo e esquizofrenia. 1. ed. São Paulo: Editora 34, 2000. v. 1.

DELEUZE, Gilles; GUATTARI, Félix. Mil Platôs: capitalismo e esquizofrenia. 1. ed. São Paulo: Editora 34, 2012. v. 2.

DELEUZE, Gilles; GUATTARI, Félix. Mil Platôs: capitalismo e esquizofrenia. 2. ed. São Paulo: Editora 34, 2012. v. 3. 
DELEUZE, Gilles; GUATTARI, Félix. Mil Platôs: capitalismo e esquizofrenia. 2. ed. São Paulo: Editora 34, 2012. v. 4.

DELEUZE, Gilles; GUATTARI, Félix. O anti-Édipo: capitalismo e esquizofrenia. São Paulo: Editora 34, 2010.

DELEUZE, Gilles; GUATTARI, Félix. O que é a filosofia? Rio de Janeiro: Editora 34, 1992.

DELEUZE, Gilles; PARNET, Claire. Diálogos. Lisboa: Relógio d’Água, 2004.

DIAS, Rosanne Evangelista; LOPES, Alice Casimiro. Sentidos da prática nas políticas de currículo para a formação de professores. Currículo sem Fronteiras, [s. I.], v. 9, n. 2. p. 79-99, jul./dez. 2009.

DOMINGUES, Petrônio José. Movimento da negritude: uma breve reconstrução histórica. África: Revista do Centro de Estudos Africanos, São Paulo, v. 26, n. 24-26 p. 193-210, 2009.

EVARISTO, Conceição. A gente combinamos de não morrer. In: EVARISTO, Conceição. Olhos d'água. Rio de Janeiro: Pallas; Fundação Biblioteca Nacional, 2015. p. 99-109.

FANON, Frantz. Pele negra, máscaras brancas. Salvador: EDUFBA, 2008.

FOUCAULT, Michel. Arqueologia do saber. Rio de Janeiro: Forense Universitária, 1989.

FOUCAULT, Michel. Microfísica do poder. Rio de Janeiro: Paz \& Terra, 2017.

FOUCAULT, Michel. O corpo utópico, as heterotopias. São Paulo: Edições $\mathrm{n}-1,2013$.

FOUCAULT, Michel. Vigiar e punir: uma história da violência nas prisões. Petrópolis: Vozes, 1997.

GADELHA, José Juliano. Cosmosensoriologia: rotas para uma metodologia fugitiva em artes. Vazantes, Fortaleza, v. 2, n. 2, p. 170-189, 2018.

GAUTHIER, Clermont. Esquizoanálise do currículo. Educação \& Realidade, Porto Alegre, v. 27, n. 2, p. 143-155, jul./dez., 2002. 
GILROY, Paul. O Atlântico Negro. Rio de Janeiro: Editora 34, 2006.

GOMES, Nilma Lino. Ações Afirmativas: dois projetos voltados para a juventude negra. In: GONÇALVES E SILVA, Petronilha B.; SILVÉRIO, Valter Roberto (org.). Educação e ações afirmativas: entre a injustiça simbólica e a injustiça econômica. Brasília: Instituto Nacional de Estudos e Pesquisas Educacionais Anísio Teixeira, 2003. p. 217-243.

GUATTARI, Félix. Revolução molecular: pulsações políticas do desejo. 3. ed. São Paulo: Brasiliense, 1987.

GUATTARI, Félix; ROLNIK, Suely. Micropolítica: cartografias do desejo. 12. ed. Petrópolis: Editora Vozes, 2013.

HALL, Stuart. Da diáspora. Belo Horizonte: Editora da UFMG, 2010.

HALPERIN, David. San Foucault: para una hagiografia gay. Córdoba: Cuadernos do Litoral, 2000.

HARTMAN, Saidiya. Scenes of subjection: terror, slavery, and self-making in nineteenth-century America. Oxford University Press on Demand, 1997.

hooks, bell. Eros, erotismo e o processo pedagógico. In: LOURO, Guacira Lopes. O corpo educado: pedagogias da sexualidade. Belo Horizonte: Autêntica, 2010. p. 113-125.

LAPOUJADE, David. Deleuze, os movimentos aberrantes. São Paulo: n-1 edições, 2015.

LARROSA, Jorge. Experiência e alteridade em educação. Revista Reflexão e Ação, Santa Cruz do Sul, v. 19, n. 2, p. 4-27. jul./dez. 2011.

LOURO, Guacira Lopes. Gênero, sexualidade e educação: uma perspectiva pós-estruturalista. Petrópolis: Vozes, 1997.

LOURO, Guacira Lopes. Um corpo estranho: ensaios sobre sexualidade e teoria queer. Belo Horizonte: Autêntica, 2004.

MACEDO, Elizabeth. Currículo como espaço-tempo de fronteira cultural. Revista Brasileira de Educação, Rio de Janeiro, v. 11, n. 32, p. 285-286, maio/ago. 2006 b. 
MACEDO, Elizabeth. Currículo e conhecimento: aproximações entre educação e ensino. Cadernos de Pesquisa, São Paulo, v. 42, n. 147, p. $716-$ 737, 2012.

MACEDO, Elizabeth. Por uma leitura topológica das políticas curriculares. Education Policy Analysis Archives/Archivos Analíticos de Políticas Educativas, v. 24, p. 1-23, 2016.

MACEDO, Elizabeth. Por uma política da diferença. Cadernos de Pesquisa, São Paulo, v. 36, n. 128, p. 327-356, maio/ago. 2006a.

MACEDO, Elizabeth. O Currículo no Portão da Escola. In.: MACEDO, Elizabeth; RANNIERY, Thiago. (orgs). Currículo, sexualidade e ação docente. Petrópolis: DP Et alli, 2017, p. 17-44.

MACHADO, Roberto. Uma geografia da diferença. Revista Cult, São Paulo, 14 mar. 2010. Disponível em: https://revistacult.uol.com.br/home/umageografia-da-diferenca/. Acesso em: 21 nov. 2018.

MARTINS, Leda. A fina lâmina da palavra. O Eixo e a Roda, Belo Horizonte, v. 15, p. 55-84, 2007.

MBEMBE, A. Necropolítica. Arte \& Ensaios, Rio de Janeiro, n. 32, p. 123151, 2016.

MBEMBE, Achille. Crítica da razão negra. São Paulo: n-1 edições, 2018.

MBEMBE, Achille. As formas africanas de auto-inscrição. Estudos afroasiáticos, Salvador, v. 23, n. 1, p. 171-209, 2001.

MISKOLCl, Richard. Machos e brothers: uma etnografia sobre o armário em relações homoeróticas masculinas criadas on-line. Revista Estudos Feministas, Florianópolis, v. 21, n. 1, p. 301- 324, 2013.

MISKOLCl, Richard. O desejo da nação: masculinidade e branquitude no Brasil de fins do XIX. São Paulo: Annablume, 2012.

MOMBAÇA, Jota. "Para desaprender o queer dos trópicos: desmontando a caravela queer". Ssexbbox, 28 ago. 2016. Disponível em: http://www. ssexbbox. com/2016/08/paradesaprender-o-queer-dos-tropicosdesmontando-a-caravela-queer. Acesso: 5 set. 2019. 
MUNANGA, Kabengele. Políticas de ação afirmativa em benefício da população ne- gra no Brasil: um ponto de vista em defesa das cotas. In: GONÇALVES E SILVA, Petronilha B.; SILVÉRIO, Valter Roberto (org.) Educação e ações afirmativas: entre a injustiça simbólica e a injustiça econômica. Brasília: Instituto Nacional de Estudos e Pesquisas Educacionais Anísio Teixeira, 2003. p. 115-128.

MUÑOZ, José Esteban. Cruising Utopia: the then and there of queer futurity. New York: New York UP, 2011.

NASCIMENTO, Tatiane. O cuírlombo da palavra (y da palavra queerlombo...). Blogueiras Negras, São Paulo, 24 set. 2018. Disponível em: https://palavrapreta. wordpress.com/2018/03/12/cuierlombismo/. Acesso em: 10 out. 2018.

OLIVEIRA, Thiago Ranniery M. Corpos feitos de plástico, pó e glitter: currículos para dicções heterogêneas e visibilidades improváveis. 2016. 402 f. Tese (Doutorado em Educação) - Universidade do Estado do Rio de Janeiro, Rio de Janeiro, 2016.

OLIVEIRA, Thiago Ranniery M. Cruor, Crudor: por uma exigência ética da crueldade curricular. In: OLIVEIRA, Thiago Ranniery M. Currículo-Teatro: uma cartografia com Antonin Artaud. 2012. 248 f. Mestrado (Dissertação em Educação) - Universidade Federal de Minas Gerais, Belo Horizonte, 2012. p. 82-107.

DE OLIVEIRA, Thiago Ranniery Moreira; PARAíSO, Marlucy Alves. Currículo, cultura e crueldade: para compor uma ética com Antonin Artaud e o teatro. Perspectiva, v. 31, n. 2, p. 615-644, 2013.

OLIVEIRA, Thiago Ranniery M.; PARAísO, Marlucy Alves. Mapas, dança, desenhos: a cartografia como método de pesquisa em educação. ProPosições, São Paulo, v. 23, n. 3, p. 159-178, set./dez. 2012.

PARAíSO, Marlucy Alves. Apresentação. In: PARAíSO, Marlucy Alves (org). Pesquisas sobre currículos e culturas: temas, embates, problemas e possibilidades. Curitiba: CRV, 2010a. p. 11-14.

PARAÍSO, Marlucy Alves. Currículo e aprendizagem: relações de gênero e raça na escola. In: SEMINÁRIO INTERNACIONAL FAZENDO GÊNERO, 7., 2006, Florianópolis. Anais [...]. Florianópolis: Universidade Federal de Santa Catarina, 2006. Tema: Gênero e Preconceitos. p. 1-8. 
PARAíSO, Marlucy Alves. Currículo-mapa: linhas e traçados das pesquisas pós-críticas sobre currículo no Brasil. Educação \& Realidade, Porto Alegre, v. 30, n. 1, 2004b.

PARAíSO, Marlucy Alves. Pesquisas pós-críticas em educação no Brasil: esboço de um mapa. Cadernos de Pesquisa, São Paulo, v. 34, n. 122, p. 283-303, 2004a.

PARAÍSO, Marlucy Alves. Um currículo entre formas e forças. Rev. Educação, Porto Alegre, v. 38, n. 1, p. 49-58, jan./abr. 2015.

PELÚCIO, Larissa. Subalterno quem, cara pálida? Apontamentos às margens sobre pós-colonialismos, feminismos e estudos queer. Contemporânea, São Carlos, v. 2, n. 2, p. 395-418, jul./dez. 2012.

PELÚCIO, Larissa. Traduções e torções ou o que se quer dizer quando dizemos queer no Brasil?. Periodicus, Salvador, v. 1, p. 15-39, 2014.

PEREZ, Léa Freitas. Dionísio nos trópicos: festa religiosa e barroquização do mundo - por uma antropologia das efervescências coletivas. In: PASSOS, Mauro (org.). A festa na vida: significado e imagens. Petrópolis: Vozes, 2002. p. $15-58$.

PINAR, William. What is curriculum theory? Mahwah: Laurence Erlbaum, 2004.

PONTES, Cassandra Marina da Silveira. Política curricular, enunciação da diferença e demandas raciais: analisando as Diretrizes Curriculares Nacionais para a Educação das Relações Étnico-Raciais e para o Ensino de História e Cultura Afro-Brasileira e Africana. 2009. 146 f. Dissertação (Mestrado em Educação) - Universidade do Estado do Rio de Janeiro, Rio de Janeiro, 2009.

POPKEWITZ, Thomas. Lutando em defesa da alma: a política do ensino e a construção do professor. Porto Alegre: Artmed, 2001.

PÓVOAS BRITO, Eliana. O currículo do Ensino Médio baiano: entre a formação integral e a valorização das diferenças. Currículo Sem Fronteiras, Rio de Janeiro, v. 18, n. 3, p. 1003-1024, set./dez. 2018. 
PRECIADO, Paul B. Entrevista com Paul Beatriz Preciado. Cadernos Pagu, Campinas, n. 28, p. 375-405, jan./jul. 2007.

PRECIADO, Paul B. Texto Junkie: sexo, drogas e biopolítica na era farmacopornográfica. São Paulo: n-1 edições, 2018.

RIBEIRO, William Goes. Remobilizando a pesquisa com o pós-estruturalismo: quando a diferença faz toda a diferença. Currículo Sem Fronteiras, Rio de Janeiro, v. 16, n. 3, p. 542-558 set./dez., 2016.

ROLNIK, Suely. O caso da vítima: para além da cafetinagem da criação e de sua separação da resistência. ARS, São Paulo, v. 1, n. 2, p. 79-87, 2003.

ROSE MARIE. Lei 'da Mordaça', aprovada por Vereadores de Porto Seguro, é equivocada e inconstitucional. Blog da Rose Marie, Porto Seguro, 21 jun. 2018. Disponível em: http://www.blogdarosemarie.com/2018/06/21/leida-mordaca-aprovada-por-vereadores-de-porto-seguro-e-equivocadae-inconstitucional/. Acesso em: 4 nov. 2019.

SAID, Edward. O orientalismo. São Paulo: Companhia das Letras, 2012.

SCHUCMAN, Lia Vainer. Entre o “encardido”, o "branco" e o “branquíssimo": raça, hierarquia e poder na construção da branquitude paulistana. 2012. 160 f. Tese (Doutorado em Psicologia Social) - Universidade de São Paulo, São Paulo, 2012.

SEDGWICK, Eve Kosofsky. A epistemologia do armário. Cadernos Pagu, Campinas, n. 28, p. 19-54, 2007.

SILVA, Tomaz Tadeu. Documentos de identidade: uma introdução às teorias do currículo. 2 ed. Belo Horizonte: Autêntica, 2007.

SILVA, Tomaz Tadeu. O Currículo como fetiche: a poética e a política do texto curricular. Belo Horizonte: Autêntica, 2006.

SOUZA, Neusa Santos. Tornar-se negro: as vicissitudes da identidade do negro brasileiro em ascensão social. Rio de Janeiro: Graal, 1983.

SPIVAK, Gaytri. Pode um subalterno falar? Belo Horizonte: Editora da UFMG, 2010. 
TADEU, Tomaz; CORAZZA, Sandra; ZORDAN, Paola. Linhas de escrita. Belo Horizonte: Autêntica, 2004.

VARELA, Julia; ALVAREZ-URIA, Fernando. A maquinaria escolar. Teoria \& Educação, Porto Alegre, n. 6, p. 225-246, 1992.

VEIGA-NETO, Alfredo. De geometrias, currículos e diferenças. Educ. Soc., Campinas, v. 23, n. 79, p. 163-186, ago. 2002. Disponível em: http://www. scielo.br/pdf/es/v23n79/10853.pdf. Acesso em: 15 jan. 2019.

ZAMBONI, Jésio. Cartografia bicha. In: PINEL, Hiran; MENDONÇA FILHO, J. Christovam (org.) Diversidade sexual: silêncio, diálogo \& currículo. São Carlos: Pedro \& João Editores, 2013. p. 101-115.

ZAMBONI, Jésio. Educação Bicha: uma a(na[I])rqueologia da diversidade sexual. 2016. 116 f. Tese (Doutorado em Educação) - Universidade Federal do Espírito Santo, Vitória, 2016.

ZAMBONI, Jésio. Gêneros dissidentes, sexualidades disparatadas e contraidentidades: travestis, sapatões, giletes, bichas e outras variações: antiprincípios para uma pesquisa-bicha. In: SEMINÁRIO INTERNACIONAL DESFAZENDO GÊNERO, 2., 2015, Salvador. Anais [...]. Salvador: EDUFBA, 2015. Tema: Ativismos das dissidências sexuais e de gênero, 2015. n.p. 


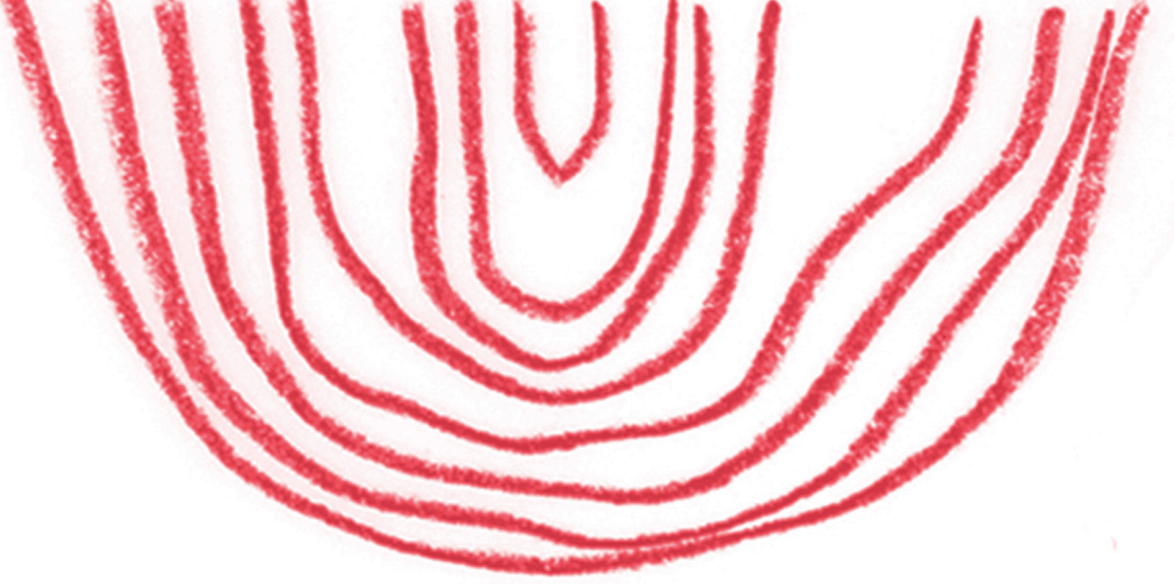




\section{posfácio}

TRANSFLUÊNCIA, LIVROS CONTRACOLONIAIS

\section{Transfluir: modos de pensar-fazer}

É preciso "superar o caráter autoritário do atual Estado Democrático de Direito", para que "toda e qualquer proposta de mudança seja exaustivamente debatida, respeitando-se as mais diversas formas de linguagem e de comunicação", escreve Antônio Bispo dos Santos (2015, p. 97), em livro intitulado Colonização, Quilombos: modos e significados.

O caminho para tal superação, nomeada pelo autor de "contracolonização", passa pela formulação de alguns conceitos teórico-metodológicos, como "confluência", "transfluência", "tradutor entre mundos", "reedição" de palavras, de narrativas e de epistemologias. Passa também pela escrita como campo de disputa, dispositivo a ser apropriado como "uma arma do inimigo para transformá-la em defesa" (SANTOS, 2018, s.p.).

Um entre esses modos de pensar-fazer, "transfluir", foi adotado por nós como nome da série de livros nascida de pesquisas de pós-graduação vinculadas à Universidade Federal do Sul da Bahia (UFSB). As três pesquisas que compõem a série saíram de cada uma das sedes da UFSB, 
divididas em três campi, constelados em rede e enraizados geopoliticamente nos municípios de Itabuna, Porto Seguro e Teixeira de Freitas.

Em agosto de 2020, firmando uma parceria interinstitucional com a Universidade Estadual de Santa Cruz (UESC), por meio de sua editora universitária, a Editus, o Programa de Pós-Graduação em Ensino e Relações Étnico Raciais (PPGER/UFSB) cria oficialmente a série de livros "Transfluência: Ensino, Gênero e Relações Étnico-Raciais”.

As três obras inaugurais dessa série foram selecionadas por meio de edital público. Puderam concorrer a esse edital todas/os que, na ocasião, estivessem vinculadas/os ao PPGER: discentes, docentes, grupos de pesquisa, comissões científicas de eventos ocorridos desde a abertura das atividades de formação do curso, em setembro de 2017. As três autorias selecionadas para os primeiros números da série são estudantes egressos da primeira turma de mestrandas e mestrandos do programa.

De modo geral, para estudantes de pós-graduação, a publicação de seus trabalhos, oriundos de projetos de pesquisas, pode significar reconhecimento público, amplo e estratégico de seus percursos formativos, escolhas e proposições teórico-metodológicas. Na tradição das Ciências Humanas, a publicação de livros é um dos caminhos para o tornar-se autor/a, reconhecida/o pelos pares. Mesmo assim, o trabalho de conclusão em nível de mestrado nem sempre toma o caminho do livro, parando no repositório institucional. Na contramão disso, esta série traz a questão da transposição da dissertação para livro, como processo formativo, como alargamento do raio de impacto dos trabalhos 
realizados no PPGER/UFSB. Além disso, põe em perspectiva o livro como retorno de pesquisas gestadas em escolas, quilombos, terreiros e aldeias, encorajando a expansão e o amadurecimento dos trabalhos de conclusão de curso no terreno da publicação como etapa legítima do desenvolvimento teórico-reflexivo.

No caso específico do PPGER, tais autorias são significativamente contra-hegemônicas, densamente territorializadas em comunidades de tradição oral, marcadamente dissidentes e insurgentes em seus contextos de produção e suas propostas epistemológicas. Participam, por essa via, do esforço de criação de diversas formas de linguagem para pesquisas resolutivas e mídias de comunicação que sejam capazes de abrir caminho à superação das colonialidades autoritárias de um Estado Democrático de Direito, que ainda não encontrou um conjunto de textos, uma convergência plural de diferentes sistemas de pensamento, capaz de assegurar os debates necessários ao viver em comum, sem a eliminação compulsória das diferenças.

\footnotetext{
Para Antônio Bispo dos Santos (2015, p. 89, grifos nossos),
}

confluência é a lei que rege a relação de convivência entre os elementos da natureza e nos ensina que nem tudo que se ajunta se mistura, ou seja, nada é igual. [...] [E contrapondo-se a essa lei,] transfluência é a lei que rege as relações de transformação dos elementos da natureza e nos ensina que nem tudo que se mistura se ajunta.

Em um tensionamento dos opostos, para Santos (2015), ainda seguindo as letras de seu livro, nós aprende- 
mos a confluir com os povos da terra, com os povos de tradição oral (quilombolas, de terreiros, povos indígenas, afroindígenas, etc.), de lógica cosmovisiva circular; e aprendemos a transfluir com os povos de tradição escrita, com lógica cosmovisiva linear e pensamento monista.

Com o abandono dos tensionamentos binários, em nossas mãos, no ponto de encontro de diferentes águas, no encruzilhar de diferentes tradições civilizatórias, detenhamos nosso olhar nas lições aprendidas no livro de Bispo dos Santos (2015, p. 89): "nem tudo que se ajunta se mistura, ou seja, nada é igual" e "nem tudo que se mistura se ajunta".

Façamos assim para, então, indagar: até onde é possível compor uma série de livros em que se guardem - sejam transmitidos - gestos múltiplos, diferenças agonísticas, autorias dissidentes, saberes insurgentes e não hegemônicos, epistemologias contracoloniais, quando nos defrontamos com as colonialidades e o racismo estrutural de nosso atual Estado Democrático de Direito?

\section{Das águas: corpos e corpus}

Trabalho com os conceitos de "confluência" e "transfluência". Confluência foi um conceito muito fácil de elaborar porque foi só observar o movimento das águas pelos rios, pela terra. Transfluência demorou um pouco mais porque tive que observar o movimento das águas pelo céu. Para entender como um rio que está no Brasil conflui com um rio que está na África eu demorei muito tempo. E percebi que ele faz isso pela chuva, pelas nuvens. Pelos rios do céu. Então, se é possível que as águas doces que 
estão no Brasil cheguem à África pelo céu, também pelo céu a sabedoria do nosso povo pode chegar até nós no Brasil (SANTOS, 2018, s.p.).

Recomecemos de outro modo. Porque, sim, as águas têm memórias. Ficam nelas entranhadas tantos lugares por onde escorrem nas veias da terra, tantas gentes e saberes que com elas fluem. Para nós, são esses rios do céu, nas ensinanças de Antônio Bispo dos Santos (2018), que inspiram o projeto editorial da série de livros "Transfluência".

De como os rios de África chegam no Brasil. De como a distância territorial, o apartamento afrodiaspórico do território não apaga os elos, os saberes, os diferentes modos de ensinar e de aprender, a comunicação entre mundos. Feitiçaria que corre pelas águas trazendo recados, recuperando histórias subterrâneas dos lençóis freáticos, dos rios que correm e a-fluem a céu aberto, dos oceanos que fazem grandes conexões continentais. A feitiçaria como tradução, como quem extrapola o interlinguístico e habita o entre-lugar dos mundos, a articulação de modos dissidentes de existir, como "um intérprete a serviço da transmutação", como ensina Tiganá Santana (2018, p. 12).

Uma série de livros escritos por autoras e autores que também se arriscam como tradutoras e tradutores interculturais e pluriepistêmicos, como corpos cognoscentes, heteróclitos e transcriativos, escrevendo um corpus, conjunto de obras, heteróclito e transcriativo. Uma série de livros como coleção bibliográfica e materialidades de experiências de vida que são resultado das pesquisas e fortuna crítica para novas pesquisas. Pensamos aqui, mais uma vez, inspiradas por algumas noções metodológicas e teóricas de 
Antônio Bispo dos Santos (2018, s.p.) - "Minhas mais velhas e meus mais velhos me formaram pela oralidade, mas eles mesmos me colocaram na escola para aprender, pela linguagem escrita, a traduzir os contratos que fomos forçados a assumir"; pela noção de transcriação de Haroldo de Campos (2013); e, sobremaneira, pela noção de história, de Beatriz Nascimento (2018, p. 333) - “A memória são conteúdos de um continente, da sua vida, da sua história e do seu passado. Como se o corpo fosse o documento".

Em seguida, Célia Xakriabá (2020) nos diz que todo corpo é território e está em movimento, em permanente (re) territorialização. E, com isso, reivindica uma educação territorializada, ao contrário daquela desagregadora, característica historicamente encarnada pelas instituições formais de ensino. "Amansar o giz", então, é "ressignificar a escola", diz ela, no reconhecimento dos valores e dos elementos de cada corpo-território, como lugar potente de articulação entre saberes, mas sobretudo com o que o território nos alimenta, nos ensina e nos constitui (XAKRIABÁ, 2020, s.p.).

Passa um córrego, corre um rio submerso, em uma das cidades-sede do PPGER, Itabuna, cujo nome é Burundanga e sobre o qual uma escola pública foi construída. Um fragmento da memória desse corrégo-rio, degradado e tornado invisível a olho nu, torna-se legível para nós a partir de uma fala-escrita de Carlos Alberto Araújo dos Santos, Egbomin Alaboji, do llê Axé ljexá Orixá Olufon. Aqui vertida, em versão transcriada, uma narrativa brota reeditada: em uma cartografia geopolítica de mar de morros, os rios Burundanga e Jeribucassu caminham juntos, fazem parte da costa rochosa no litoral sul da Bahia. Córrego, rio, BURUNDANGA. Aqui, 
como nas Africanidades diaspóricas, as línguas, os corpos e as paisagens caminham juntos, perfazem encontros afroindígenas: Buru: enorme; Dan: serpente; Ga: alto. BURUNDANGA. A serpente que veio e nasceu do alto. Seixos de línguas: tupi, iorubá. Em relação à topologia cultural da nascente desse córrego, ou rio, dizemos: as águas descem do alto serpenteando. Dito de outro modo, "as águas descem sinuosas como uma enorme serpente". Nessa manhã inaugural, que perdura ainda, "em que o céu está em festa e mais colorido: a Serpente Sagrada do Povo Gege risca os Céus!”.

Temos aprendido com nossos mais velhos, pela oralidade e pela escrita. Reeditando narrativas, aprendemos. Somos feitos de muitas comunidades, de mil povos e incontáveis nações. As mais de mil nações dos povos originários, entre as quais estão os Tupinambá, os Pataxó, os Pataxó Hã Hã Hãe, que habitam regiões ancestrais e contemporâneas no Sul da Bahia e nos ensinam seus modos de fazer-pensar; e as nações diaspóricas africanas são muitas, sabem ser uma e ser mil, a uma só vez:

\begin{abstract}
A sobrevivência da cultura africana se fez no Brasil a partir de três grupos ou três nações: a Gege, que está quase acabando, a Ketu que domina hoje, que centraliza hoje uma ortodoxia, uma teologia que é Ketu-Nagô, porque há várias nações Nagôs e o Angola, que é talvez o sincretismo brasileiro dessas experiências africanas (NASCIMENTO, 2018, p. 333).
\end{abstract}

Sobrevivências, re-existências, corpos com memória de águas e das paisagens que habitamos. Atravessados por 
pensamentos, teorias, métodos, cartografias, biografias e narrativas, trajetos de pesquisas, transfluentes, como bem sabem ser as águas das chuvas, dos rios, dos mares, dos mangues, da terra; e confluentes, como bem sabem ser as/ os que perfazem diferentes ciclos de mundos no mundo. São com tais corpus e corpos que esperamos fazer compor e ampliar, ano a ano, a série aberta de livros "Transfluência: Ensino, Gênero, Relações Étnico-Raciais".

Um corpus, portanto, para a série "Transfluência", como corpo-território, corpo-documento, como política editorial, que deseja se alinhar às genealogias orais de linhagem de livros que se sabem atos estético-políticos, cognitivos e de ensino. Para essas linhagens, há escritas não alfabéticas. Escritas de águas. Escritas das matas. Escritas de milênios, como pinturas rupestres, cantos, ritmos poéticos e de pensamentos orais, inscrições, demarcações de passagens, não de posse, mas de pertencimento, de partilha de vida, de bem comum.

\section{Tipografias líquidas, livros contracoloniais}

Tendo tudo isso em vista, como chegar no livro? O livro como materialização das brechas e flechas lançadas pelo nome que abre caminho dessa série? Que visualidades podem o constituir? Como curá-lo em seus caminhos editoriais e projeto gráfico?

O livro, como território historicamente aliado dos abusos e estigmas do Estado de Direito, assume toda a estirpe colonial como objeto de catequização e domínio. Opõe-se à oralidade. Afirma a escrita logocêntrica, alfabética. 
Como pensar, porém, o livro de outro lugar? Como território potente de transformação, como trânsito entre mundos, como tramas interétnicas, como processos de subjetivação em trânsito, instáveis, dissidências, afirmação em devir.

Como pensar agora o livro aberto, o livro mundo? O livro para fora, nas comunidades escolares, nas comunidades de terreiro, nas comunidades quilombolas, no enfrentamento das questões de gênero e dissidências sexuais? O livro cuja página é a floresta, cujas linhas são lidas na caída dos búzios, cujas grafias são a pele e suas inscrições sábias do tempo no corpo, livros-peles, livros-lugares.

Reconhecer o livro fora dos domínios da colonialidade, ver o livro aberto, implicado no território, a transfluir águas. Nelas: entes, encantados, voduns, orixás, inkises, ritos, saberes, narrativas, orikis, rezas, geomitologias, os diferentes corpos que as habitam, muitas dimensões do humano e de diversas cosmopercepções.

Vejamos o livro de água gráfica, da nascente à foz, do mar aberto à areia da praia, da lama profunda à superfície do mangue, tantas escritas e inscrições: quando a água passa, perfaz caminhos, ranhuras, topografias. Tantas memórias fincadas no chão por onde ela passou. No correr da viagem de uma vida que faz um rio: muitas águas se encontram. $O$ encontro aqui é signo de movimento e mudança permanentes. O rio transcorre pelo território como uma cobra mudando de pele, na transmutação ligeira do espaço-tempo. É imperativo, sempre, continuar, como esta série de livros o fará.

O encontro é também faísca que transcorre quente, sinergia potente de criação, fricção. Quantos maus encon- 
tros promovidos pela colonização afro-pindorâmica, responsáveis por desterritorializações e reterritorializações monumentais e genocidas, transcorridas das águas de Áfricas embarcadas e aportadas nas Américas. Quantos encontros potentes de força encantatória também não se deram no bojo dessa invasão, tantas vezes reinstaurada no curso do tempo, entronizada no Brasil como projeto de normatização, sendo o encantamento "ato de desobediência, transgressão, invenção e reconexão: afirmação da vida" (SIMAS; RUFINO, 2020, s.p.).

As águas guardam, portanto, a memória desses tantos encontros de conexões afro-pindorâmicas, em diversas dimensões. Thiago de Melo (1984, p. 157-158) diz que as águas nunca se desgastam: "permanecem nas águas os elos das correntes invisíveis". Pois quantas marés há na memória da chuva? E na "maré dos olhos" como a "memória das corredeiras" que escapa do olhar perdido do velho Agodô no conto de Cidinha da Silva (2018)? "Devo contar o vivido, velho Agodô? Conte o que fizeste dele, minha filha. Isso basta, meu velho? Se basta não sei. Aviva" (SILVA, 2018, p. 27-28)? O corpo da terra, o corpo das gentes, corpo líquido, corpo vivo.

Se ainda é possível transfluir essas conexões, como nos convoca Antônio Bispo (2015, 2018), como os rios do céu que choram na chuva e nos trazem de volta memórias invisíveis, confluências continentais, fluxos e refluxos da transmutação da natureza, o livro aqui se coloca também como território de encontros. De modo que foi a água a chave-mestra do processo criativo do projeto gráfico desta série de livros, talhada em um conjunto de carimbos que, em 
relação, organizam e re-organizam múltiplos movimentos visuais. As águas e as cores. Cores terrosas, cores vibrantes. Tipografias líquidas. Nos carimbos, confluência de cores, de lógicas e de tempos históricos: a modernidade e a tradição sobrescritos no tempo presente. Carimbos gráficos, sulco artesanal na madeira, transposição ao digital, com combinações múltiplas, que denunciam sua técnica na textura, imperfeita e precisa, de fluxos vincados em sua matéria-prima. Gestos, traços de quem imprime como quem assenta na página percursos possíveis do macroterritório do Sul da Bahia. Essa é a nossa direção editorial.

\section{Agradecimentos}

Um livro, uma série de livros, não se concebe e nem se faz com poucas pessoas envolvidas. Há muito a agradecer. Mesmo correndo o risco de deixar de fora algum nome, e pedindo antecipadamente desculpas se isso ocorrer, agradecemos aos coordenadores locais do PPGER, Eliana Póvoas Pereira Estrela Brito e Gilson Brandão de Oliveira Junior. Ao coletivo de professores e discentes, e especificamente aqueles que trabalharam na Comissão de Seleção das obras: Hamilton Richard A. F. Santos, Francisco A. Nascimento Junior, Yuri Miguel Macedo (do campus Sosígenes Costa, PPGER Porto Seguro); Rebeca Valadão Bussinger, Francisco Antônio Nunes Neto, Paulo César Pereira de Jesus (do campus Paulo Freire, PPGER Teixeira de Freitas); Apoena Dandara Silva Santos (do campus Jorge Amado, PPGER Itabuna). Agradecemos a Rita Virgínia Argollo, Sabrina Nascimento, Conselho Editorial e toda equipe da Editus, parceria indispensável neste projeto. À equipe de revisores, José Pedro de 
Carvalho Neto e Tess Chamusca Pirajá. À equipe de artistas gráficos, Lia Cunha e Tiago Ribeiro. Às instituições Universidade Federal do Sul da Bahia e Universidade Estadual de Santa Cruz, com suas equipes de servidores públicos que viabilizaram cada passo do processo. Agradecemos aos autores que inauguram esta série de livros: Raíssa Félix, Kauan Almeida e Ademar Cirne, pelas trocas e aprendizados mútuos nesta tarefa de fazer chegar ao mundo dos livros seus percursos de pesquisa. Agradecemos, por fim e por início, a Kabengele Munanga: nosso mais velho, companhia que nos honra, nos fortalece, nos alegra, ao nos acolher e nos ensinar tanto e ao modo firme dos aquilombamentos ancestrais.

Cynthia Cy Barra e Laura Castro

Coordenação Editorial do Projeto Transfluência Itabuna; Salvador, Bahia, outubro de 2020. 


\section{REFERÊNCIAS}

CAMPOS, Haroldo de. Tradição, transcriação, transculturação: o ponto de vista do excêntrico. In: TÁPIA, Marcelo; NÓBREGA, Thelma Médici (org.). Haroldo de Campos - Transcriação. São Paulo: Perspectiva, 2013. p. 197205.

MELO, Thiago. Vento geral. Rio de janeiro: Civilização Brasileira, 1984.

NASCIMENTO, Maria Beatriz. Beatriz Nascimento: intelectual e quilombola. Possibilidade nos dias da destruição. São Paulo: Editora Filhos da África, 2018.

SANTANA, Tiganá. Breves considerações sobre um traduzir negro ou tradução como feitiçaria. Landa, Florianópolis, v. 7, p. 5-16, 2018. Disponível em: https://repositorio.ufsc.br/bitstream/id/ebf57f17-45934dcO-abe4-1d3212e4bf95/1.\%2OTIGANA\%20-\%2OLISTO.pdf. Acesso em: 2 out. 2020 .

SANTOS, Antônio Bispo. Colonização, Quilombo: modos e significados. Brasília: INCTI; UnB; INCT; CNPq; MCTI, 2015

SANTOS, Antonio Bispo. Somos da terra. Piseagrama, Belo Horizonte, n. 12, 2018. Disponível em: https://piseagrama.org/somos-da-terra/. Acesso em: 2 out. 2020.

SILVA, Cidinha da. O velho e a moça. In: SILVA, Cidinha da. Um Exu em Nova York. Rio de Janeiro: Pallas Editora, 2018. p. 27-28.

SIMAS, Luiz Antônio; RUFINO, Luiz. Encantamento (sobre política de vida). Rio de Janeiro: Mórula Editorial, 2020.

XAKRIABÁ, Célia. Amansar o giz. Piseagrama, Belo Horizonte, n. 14, 2020. Disponível em: https://piseagrama.org/amansar-o-giz/. Acesso em: 2 out. 2020. 


\section{sobre o autor}

Kauan Almeida é mestre em Ensino e Relações Étnico-Raciais pela Universidade Federal do Sul da Bahia (PPGER/UFSB) e, atualmente, é doutorando pelo Programa de Pós-Graduação em Educação da Universidade Federal do Rio Grande do Sul (PPGEdu/UFRGS). Nascido em agosto de 1992, tem por menção mais valiosa a poesia como modo de encantamento pelo mundo e pelas (im)possibilidades do vir a ser. Filho de Nivanete Santos de Almeida e Valdenir Temoteo de Almeida, tem como herança o carinho pelo gesto do palavrear como singularização da educação. 
Colofão

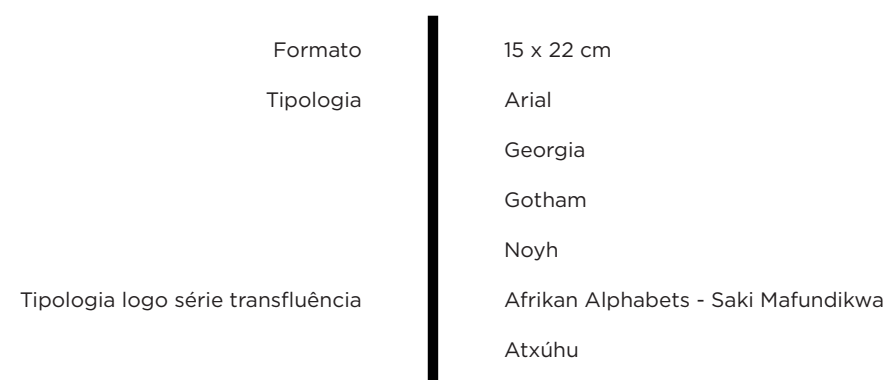


Embora a coisa de se dizer bicha e preta sempre seja lida como uma tragédia social, alvo das discriminações mais diversas, é desde este local que enuncio as possibilidades de inventar narrativas alterizadas. Recontar nossas histórias negras e dissidentes sexuais para erigir cuírlombos, conceito que tomo de empréstimo da Tatiana Nascimento (2018). Deste duplo local, que é uma paisagem em movimento, produzimos ferramentas conceituais que desmantelam o que, durante muito tempo, nas comunidades negras, se costumou chamar de "praga branca", como se a negritude fosse uma experiência que se afirmasse unicamente na heterossexualidade. Por isso, digo a você, leitora, que embora a constituição colonial de nossas instituições esteja pronta para nos esmagar, elas nunca serão grandes o suficiente para estrangular nossa capacidade de imaginar, de criar, de produzir bonitezas para além das visualidades estanques que nos acostumaram. O banzo não é capaz de deter os fluxos das diferenças dos corpos que, lançados no oceano, nos molham os pés à praia. E chego à escola, o meu local de pesquisa. Ta-Nehisi Coates (2015, p. 32) diz que "se você não compreender as ruas, terá desistido do seu corpo agora. Mas se não compreender as escolas, desistirá do seu corpo depois".

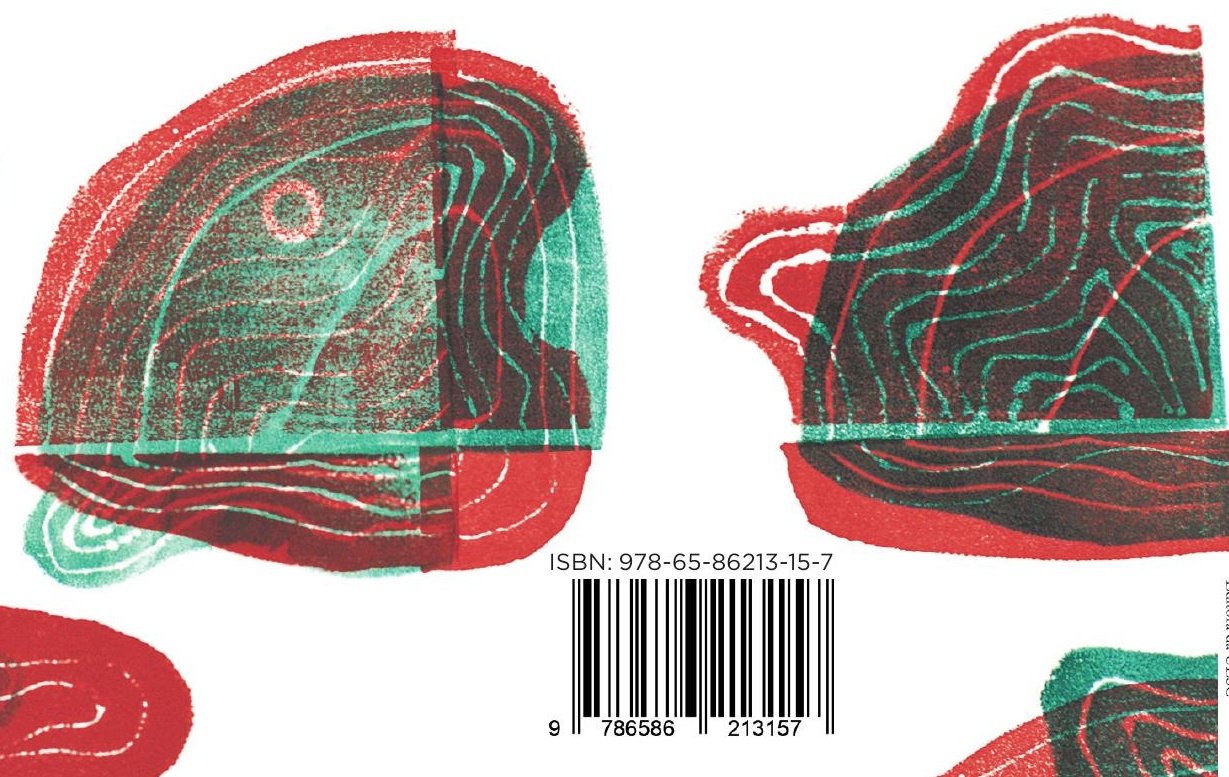

